\title{
NO UNIVERSO DAS HISTÓRIAS: Oficinas de Redação e Criatividade
}

Andrea Pacetta de Arruda Botelho

Texto apresentado ao Instituto de Psicologia da Universidade de São Paulo como parte dos requisitos para obtenção do grau de Mestre em Psicologia. Área de Concentração: Psicologia Escolar e do Desenvolvimento Humano.

orientador: Prof. Dr. Lino de Macedo

São Paulo, 1998 
Cláudia, mana querida e minha primeira professora, dedico este trabalho a você, que me ensinou a ler, escrever e amar as histórias. Muito nova aprendi com você, só um pouco menos nova, a aprender brincando. Quando a gente "brincava de escolinha", a mamãe não podia imaginar o quanto aquilo era sério!!

Beijos gigantes da sua irmãzinha. 
AgRADECIMENTOS 
Ao meu querido orientador Lino de Macedo, por ter confiado em nós. 
À CAPES, pela bolsa de Mestrado concedida. 
A Celso, Gabriela, Graziela, Maiara, Pedro e Talita, por sua presença nas oficinas e por sua generosidade ao me mostrar tantas coisas. 
A Eliana, Idalina, Neive, Telma, Sueli, Sueli e seus maridos, por terem me confiado seus filhos.

A Eni Aparecida Aliberti Galego, por ter aberto as portas para mim.

À minha mãe, Nilze, minha primeira leitora, pelo constante estímulo (desde sempre!). Também agradeço por ter me dado não somente "uma mãozinha", mas duas, ajudando-me a transcrever fitas com tanto bom humor. Além das mãozinhas, agradeço pelos olhões, caçando erros.

Ao meu pai, Rodrigo, pelo apoio. Agradeço também, já que estou falando de histórias, por ter me incentivado tanto a ler Isabel Allende.

A Virgínia Balau, madrinha deste trabalho, inúmeras ave-marias... Pelas suas lágrimas, por seu estímulo inaquilatável, por suas dicas e também - claro pelos bons papos e deliciosos chás.

A Samir Meserani, padrinho deste trabalho, em quem encontrei um grande exemplo e também um divertidíssimo amigo.

A Edvaldo Pereira Lima, por muitas ferramentas e experiências significativas com o criar. brincar.

A Gilberto Safra, por sua delicadeza e pelo resgate de minha confiança no

A Emir Tomazzelli, por tanta Presença; pelo exemplo vivo de um fazer oriundo do ser.

Ao Saulo, meu amor e meu camera man preferido, pelo encorajamento constante e pela compreensão quando de minhas ausências nas cervejinhas de ultimamente...

À Dulce que, com suas mãos de fada, dispensa-me cuidados especiais "master-super-plus"! Agradeço também pelo constante incentivo "no mundo das histórias".

Ao Sérgio e ao Dr. José Roberto, que também cuidam de mim.

A Márcia Vescovi Fortunato, minha mais recente professora de redação, pelo diálogo frutífero, pelas idéias, dicas, bilhetinhos via Internet...

A Erson M. de Oliveira, com quem exercitei a humildade diante do texto.

A Ivaldo Bertazzo, por seu bom humor e pelo muito que venho aprendendo sobre o corpo humano em movimento.

À Nícia, por seu toque preciso, firme e acolhedor. 
Aos colegas e professores da Biodinâmica, com quem compartilhei céus e infernos da maravilha humana.

Aos meus clientes e ex-clientes, que me ensinam e me ensinaram tanto.

A Cristina D. Allessandrini, pelo convite para o curso de Escrita Total.

Aos colegas da pós-graduação - Cris, Emir, Florival, Kika, Luana, Lúcia, Márcia, Marilda, Osvaldo, Sávio e Telma -, companheiros nesta viagem, por suas críticas construtivas.

A todos os ex-colegas de grupos de criação textual - especialmente Clarisse, Alberto, Antonio Carlos e José Luiz - que compartilharam comigo um mergulho profundo na escrita.

Às ex-colegas do Laboratório de Psicopedagogia, onde nasceu meu amor pela área de Educação.

À Magda, por ter me conduzido à escola onde realizei as oficinas.

Ao Digo, pelo exemplo de amor aos livros.

À Gê, por sua companhia amiga e também por suas sopas deliciosas e outros quitutes.

À tia Ruth, que acreditou em minhas propostas e experimentou algumas com seus alunos. Agradeço-lhe também por ter sido sempre uma referência como professora de verdade.

A "tia" Angélica, "tia" Cecília, Dona Lali, Dona Leonor, Afonso Aquino; enfim, a todos os meus Professores com "P" maiúsculo. crianças.

A Regina Machado, pela confiança contagiante nas histórias e nas

Aos ex-alunos da Escola da Vila, pela paciência que tiveram comigo como professora principiante, pelo carinho e pelo muito que me levaram a aprender.

Aos ex-colegas da Escola da Vila que me deram chances de aprender.

A Mario Prata, por ter me apresentado ao Samir.

A Alcina Maria de Moraes, por me guiar em bons caminhos.

A Deus, aos santos e anjos que invoco em minhas preces.

Enfim, a todos aqueles que, de alguma forma, estão presentes entre as fibras que compõem a trama deste texto. 


\section{EROS E PSIQUE}

... E assim vedes, meu irmão, que as verdades que vos foram dadas no Grau de Neófito, e aquelas que vos foram dadas no Grau de Adepto Menor, são, ainda que opostas, a mesma verdade.

Do Ritual do GRau de MESTRE do Átrio

NA ORDEM TEMPLÁRIA DE PORTUGAL

Conta a Lenda que dormia

Uma princesa encantada

A quem só despertaria

Um infante, que viria

Mas cada um cumpre o Destino -

De além do muro da estrada.

Ela dormindo encantada,

Ele tinha que, tentado,

Ele buscando-a, sem tino

Vencer o mal e o bem,

Pelo processo divino

Antes que, já libertado,

Que faz existir a estrada.

deixasse o caminho errado

$E$, se bem que seja obscuro

Por o que à Princesa vem.

Tudo pela estrada fora,

E falso, ele vem seguro,

A Princesa Adormecida,

Se espera, dormindo espera.

$E$, vencendo estrada e muro,

Sonha em morte a sua vida,

Chega onde em sono ela mora.

e orna-lhe a fronte esquecida,

Verde, uma grinalda de hera.

$\mathrm{E}$, inda tonto do que houvera, À cabeça, em maresia,

Longe o Infante, esforçado, Ergue a mão, e encontra hera,

Sem saber que intuito tem, $E$ vê que ele mesmo era

Rompe o caminho fadado.

A Princesa que dormia.

Ele dela é ignorado.

Ela pra ele é ninguém.

Fernando Pessoa*

* Obra Poética, p. 181 


\section{INDICE}

Resumo

Abstract.

I- INTRODUÇÃo

II- ObJetivo e Justificativa.

III- FILIAÇÃo TEÓRICA. .20

IV- CONSIDERAÇÕES SOBRE O CRIAR. .21

V- Metodologia, Resultados e Discussão

V.1- SUJEITOS. 27

V.2- MATERIAL. 27

V.3- LOCAL 27

V.4- Procedimentos 27

V.4.a) Sobre leitura e produção de textos nesta escola..................... 27

....V.4.b) Estudo prévio........................................................... 30

.....V.4.c) As Oficinas de Redação e Criatividade .................................. 31

V.4.c.i) Sobre as atividades ........................................... 32

. Atividades corporais............................................... 33

Exploração do tema do dia......................................... 35

Estimulação da criatividade........................................ 35

Produção escrita..................................................... 36

V.4.c.ii) Relato comentado das oficinas............................... 38

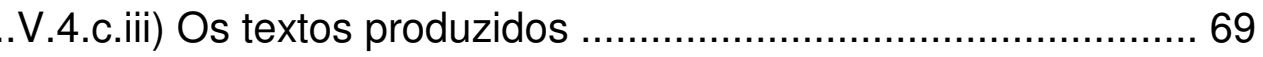

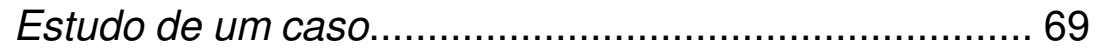

Análise genérica dos outros textos............................. 79 
V.4.c.iv) As imagens produzidas............................................113

... V.4.c.v) Apreciação das oficinas do ponto de vista dos participantes, de suas mães e de suas professoras ..........................................135 Entrevistas e questionário...........................................135 Análise por recortes temáticos: interesse e desempenho na escrita. .136 Um aceno à cooperação: outro aspecto que veio à tona numa entrevista. 137

\section{APÊNDICE DO ITEM V.4}

SOBRE CONTOS: TERMINOLOGIA E CONSIDERAÇÕES TEÓRICAS

Os contos populares maravilhosos, de magia, de fadas.. 138

Os tipos de personagens.

Estrutura e transformações nos contos populares de magia. 143

Os contos pulsam: a fórmula simplificada. 146

\section{VI- METÁFORAS DO CONTO POPULAR OU O CONTO POPULAR COMO METÁFORA}

.....Pulsação e transformação: equilibração majorante. 148

.....Artesanato e conto popular: algumas considerações sobre a experiência estética.

VII- DISCUSSÃo E CONSIDERAÇÕES FINAIS 154

.....Impacto estético na leitura e na escrita. 154

....Uma dupla perspectiva: pedagógica e psicológica. 156 .....Alinhavo. 157

VIII- REFERÊNCIAS BIBLIOGRÁFICAS. 162 
1- "O gato, o mago e o príncipe"

2- "A guerra entre o mundo das fadas e o mundo dos homens"

3- Sobre a diferença entre gnomos e duendes

4- "O monstro"

5- "A misteriosa caixa de Pandora"

6- "Em visita ao Olimpo"

7- O patinho feio

8- "O rei barba-de-melro"

9- Metáfora

10- Ficha do conto

11- Roteiro do conto

12- Questionário de avaliação pessoal das oficinas

13- Encadeamento

14 - Entrevistas com a coordenadora e com as professoras sobre as atividades de leitura e escrita propostas em sala de aula, nesta escola

15- Dados referentes ao interesse das crianças pelas atividades realizadas nas oficinas, por leitura e escrita em geral e por continuar freqüentando Oficinas de Redação e Criatividade

16- Dados referentes ao desempenho das crianças na escrita

17- Trechos de entrevista referentes à cooperação

18- "Chapeuzinho Vermelho"

19- O Chapeuzinho Vermelho

20- "Joãozinho e Mariazinha"

21- "Maninho e Maninha"

22- "O quadro de pano"

23- "A gata borralheira"

24- "O castelo de Soria Moria" 


\section{RESUMO}

BOTELHO, Andrea Pacetta de Arruda. No universo das histórias: Oficinas de Redação e Criatividade. São Paulo, 1998. Dissertação (Mestrado). Instituto de Psicologia, USP.

Relata uma experiência pedagógica, dentro de uma abordagem psicológica, realizada em forma de oficinas, nas quais foram desenvolvidas atividades visando fornecer instrumentos para a escrita de histórias - entrevendo um objetivo mais amplo de promover uma construção de conhecimentos sobre a escrita em geral -, explorando principalmente o universo os contos populares de magia. Seis crianças, com idade entre nove e onze anos, aproximadamente, freqüentaram 25 oficinas, compreendidas no decorrer de dois anos. Participaram de atividades tais como movimentar o corpo, consultar livros, ouvir histórias contadas e lidas, praticar técnicas de escrita criativa, fazer trabalhos plásticos etc. Analisa o processo principalmente segundo dois recortes temáticos: "desempenho na escrita" e "interesse". Quanto ao primeiro, observa que todas as crianças apresentaram um bom desenvolvimento ao longo dos textos produzidos. Quanto ao segundo, apresenta dados indicadores de que 0 interesse por leitura e escrita em geral aumentou, e, em relação às atividades nas oficinas, observa que manteve-se alto na maior parte do tempo, tendo oscilado em alguns momentos. Com base nos referenciais teóricos de Jean Piaget e Donald W. Winnicott, faz um balanço de todas as atividades, avaliando sua eficiência em cativar 0 interesse, a atenção e 0 envolvimento dos participantes, pontuando os momentos bem sucedidos e os mal sucedidos quanto aos últimos, critica a metodologia empregada e indica outros caminhos possíveis. Conclui que o interesse é reduzido sempre que uma atividade relega o fazer ativo e significativo das crianças; inversamente, é grande o envolvimento nos trabalhos interativos, em grupo, e nas atividades em que se considera a importância do brincar. 


\begin{abstract}
BOTELHO, Andrea Pacetta de Arruda. No universo das histórias: Oficinas de Redação e Criatividade (In the universe of stories: Composition and Creativity Workshops). São Paulo, 1998. (Master's Dissertation). Instituto de Psicologia, USP.
\end{abstract}

Outlines a pedagogical experience, within a psychological approach, that took place in workshops, which developed activities intending to offer tools to story writing - with the aim of promoting a building of knowledge concerning writing in general -, exploring mainly the world of folk magic tales. Six children aging from 9 to 11 attended to 25 workshops over two years. They took part in activities such as body movements, consulting books, listening to stories narrated and from books, practicing creative writing techniques, making handicraft etc. Analises the process mainly refering to two outline themes: "writing performance" and "interest". Concerning to the first, observes that all the children showed a good development in writing stories. Concerning to the latter, presents data that indicate that interest in reading and writing in general increased and, in relation to the proposed activities, it was high most part of the time, having oscilated in some moments. Grounded in the theoretical referencies of Jean Piaget and Donald Winnicott, considers all the activities and evaluates their efficiency in captivating the interest, attention and the envolvement of the participants, indicating the successes and failures - concerning the latter, criticises the methodology employed and indicates other possible solutions. Concludes that the interest is reduced when an activity relegates the active and significant doing of the children; inversely, the involvement is great with interactive works, in groups, and in activities in which the importance of play is considered. 


\section{I- INTRODUÇÃO}

Sabemos bem que, no desenvolvimento histórico, a autoridade para expressarse por escrito esteve concentrada em poucas mãos. A democratização, neste campo, passou pela autorização para ler o produzido por outros; ainda é preciso defender 0 direito de todos de falar em voz alta. Porque poder pôr sua palavra por escrito é poder falar em voz alta. (...)

É importante ter cada vez mais pessoas em condições de produzir textos, porque existe um risco enorme, nesta sociedade consumista em que vivemos, de pensar nos leitores exclusivamente como consumidores de textos. (FERREIRO, Emília. "A Formação do Leitor")

No texto do qual extraí esta epígrafe, Emília Ferreiro faz a seguinte consideração: da mesma forma que não se pode construir a linguagem oral apenas escutando, mas também falando, não se deve tampouco pensar na construção da leitura descolada da produção de textos.

Assim, a "autoria" (aqui entendida simplesmente como a produção de textos próprios) assume grande importância numa apropriação global da linguagem. Exercê-la é uma oportunidade de ocupar um lugar dinâmico, a partir do qual se vai além do enunciar. ${ }^{1}$ Portanto, é relevante que se desenvolvam propostas de intervenção que visem à formação da criança produtora de textos inventados por ela mesma. A "cozinha" da produção escrita não deve ser encarada como um privilégio reservado a poucos iluminados e sim como um possível a ser desmistificado, desvendado, trabalhado, democratizado.

Há muitos autores interessados nesta questão e preocupados em oferecer idéias para se trabalhar com a criação de textos em sala de aula. Samir Meserani propõe, na série didática O Prazer da Redação (da qual tive a honra de participar, no quarto volume, com dois textos): valorizando a importância da reprodução (cópia) e da paráfrase (escrita do mesmo texto em outras palavras), é importante também começar desde cedo (primeiro e segundo ciclos) um trabalho voltado para a criação de textos. ${ }^{2} \mathrm{O}$ desejo de fazer este estudo nasceu de uma paixão

\footnotetext{
Sobre a noção de autoria, Eduardo Calil escreve: "Assumo essa noção como um lugar discursivo/enunciativo, no qual o sujeito-escrevente (aquele que escreve) pode-se colocar e, ao mesmo tempo, ser colocado. É um lugar em movimento, flutuante, não fixo, em última instância, é um lugar de constituição do próprio sujeito.” (CALIL, Eduardo. Por que escrever histórias inventadas.)

${ }^{2}$ Vale lembrar a "suspeita" de Samir Meserani: "Tudo estaria tranqüilo dentro dos muros escolares, não fosse um fato digno de observação, sobretudo por ser paradoxal. Ainda que o sistema escolar seja estruturado para a reprodução, nele pulsam sonhos de criação. (...) Nela [escola], ao lado de aulas e redações meramente reprodutivas ou sob a forma de paráfrases, ocasionalmente cintilam aulas criativas, redações marcadas pela diferença e um ou outro texto didático original. Raramente. (...) Suspeito que o escriba tenha desejos de ser
} 
antiga por ler e escrever histórias ${ }^{1}$, aliada a essa idéia de que há muitas coisas que podem ser aprendidas a respeito do processo de criação e produção de um texto - algo diferente do tão conhecido método (ou "anti-método") segundo o qual o professor entra um belo dia na sala de aula e diz: "Hoje é dia de redação." Dá um título ou tema, ou simplesmente diz que o tema é livre - para o desespero daqueles que acreditam não ter "talento" para escrever - e faz, com absoluta boa intenção, a velha recomendação: "A redação tem de ter começo, meio e fim." Já é melhor do que este anti-método a idéia de usar um texto como base, como no caso do exercício da paráfrase. Pelo menos o aluno não fica "boiando" tanto. Mas e quando não houver essa base? Estará claro o que é preciso haver no começo, no meio e no fim de um texto para que possa ser considerado uma "boa redação"?

A redação freqüentemente só passa a ter um papel mais relevante a partir do ginásio e principalmente no colegial, quando o monstro chamado vestibular ameaça devorar adolescentes despreparados para lidar com o "papel em branco". Não é raro "dar um branco".

Hoje em dia estão sendo desenvolvidos muitos trabalhos, principalmente a partir do ginásio, que procuram dar conta de aproximar o que se recebe dos deuses $\left(\mathrm{dom}^{2}\right.$ ) do que pode ser trazido por humanos mortais: os professores. Ou seja, sem negar que existam diferenças individuais em termos de habilidade para escrever, acredita-se que haja algo nesse campo a ser aprendido desde cedo; portanto, também a ser ensinado.

\footnotetext{
escritor." (MESERANI, Samir. O intertexto escolar: sobre leitura, aula e redação. p. 62-63)

${ }^{1}$ História ou estória: é uma questão de escolha. Pode-se usar o termo "estória" para designar narrativas de ficção, em contraposição a "história". Mas aqui seguiu-se a recomendação do Dicionário Aurélio Eletrônico (Idem) - a não ser, obviamente, nas citações: "Recomenda-se apenas a grafia história, tanto no sentido de ciência histórica quanto no da narrativa de ficção, conto popular, e demais acepções."

${ }^{2}$ Verbete: dom

[Do lat. donu.]

S. m.

1. Donativo, dádiva, presente: "Prova. Olha. Toca. Cheira. Escuta. / Cada sentido é um dom divino." (Manuel Bandeira, Estrela da Vida Inteira, p. 20.)

(BARROSO, MÁRCIO E. G - Dicionário Aurélio Eletrônico)

2. Dote ou qualidade natural, inata.
} 


\section{II- OBJetivo E Justificativa}

O objetivo deste trabalho foi o de realizar uma experiência visando fornecer instrumentos a um grupo de crianças para criar histórias, despertar seu interesse por escrever e ler ou no mínimo propiciar uma relação não-traumática com estas atividades, oferecendo um espaço interativo lúdico e informativo no qual pudessem "apresentar-se" de diversas formas. Ou seja, nas Oficinas de Redação e Criatividade, realizaram-se propostas a partir das quais cada criança apresentou algo seu ${ }^{1}$ no universo das histórias, podendo estruturar este algo em forma de imagem gráfica e/ou, gesto, objeto, texto etc. Para isso, desenvolveu-se um trabalho informativo e vivencial sobre elementos fundamentais da narrativa de contos maravilhosos - mais especificamente de contos de magia (como será explanado mais adiante) - principalmente no que se refere ao elemento "personagem" e à estrutura da narrativa.

E para que isso pode servir?

O pano de fundo do estudo é a noção segundo a qual a narrativa desses contos tem elementos básicos, presentes na maioria dos outros tipos de histórias. ${ }^{2}$ Acredita-se então que o conhecimento desses elementos seja útil para a criação de histórias; como um desdobramento disso, útil também para a produção de textos em geral. Trata-se de oferecer chances para que as crianças comecem desde cedo a lidar com a escrita com mais intimidade, o que me parece não só importante como também urgente - algo de que dificilmente discordarão os professores em geral (inclusive universitários), entre os quais é comum ouvir a queixa de que poucos de seus alunos sabem escrever de forma minimamente articulada. $^{3}$

\footnotetext{
1 "Seu" no sentido de ter uma organização específica articulada por uma determinada pessoa, nesse sentido, original e criativa - mesmo que contenha elementos colhidos aqui e ali.

2 “(...) não avançaremos mais sobre as funções de Propp senão para sugerir, a quem se interessar, que se exercite confrontando a sequiência de funções com a trama de qualquer um dos filmes do Agente 007: surpreendentemente encontrará um grande número delas, às vezes na ordem exata, tão viva e insistentemente presente está a estrutura fabulística ${ }^{2}$ na nossa cultura. Com muitos outros livros de aventura ocorrerá a mesma coisa." (RODARI, Gianni. Gramática da Fantasia. p. 67)

3 "Às vezes me parece que uma epidemia pestilenta tenha atingido a humanidade inteira em sua faculdade mais característica, ou seja, no uso da palavra, consistindo essa peste da linguagem numa perda de força cognoscitiva e de imediaticidade, como um automatismo que tendesse a nivelar a expressão em fórmulas mais genéricas, anônimas, abstratas, a diluir os significados, a embotar os pontos expressivos, a extinguir toda centelha que crepite no encontro das palavras com novas circunstâncias.
} 
Considerei, para a escolha do recorte que daria ensejo ao desenvolvimento deste trabalho, o fato de a literatura poder ser um veículo para a elaboração de conflitos psíquicos das crianças dentro da escola, na medida em que este campo oferece uma profusão de imagens capazes de conferir significado à experiência de cada indivíduo. ${ }^{1}$ No presente estudo, observei o aspecto psicológico de forma livre, a partir da experiência em si e dos registros da mesma.

O principal recorte escolhido dentro da literatura é o universo do conto popular $^{2}$ (especialmente as histórias que têm a estrutura básica dos contos de magia, tal como será definida adiante), embora outros universos literários também tenham sido abordados em alguns momentos.

Os contos populares e principalmente os contos de magia tratam de questões que dizem respeito ao humano. Falam de sentimentos humanos (invejagratidão, arrogância-humildade, amor-ódio, desprezo-respeito, coragem-medo) e valores humanos (honestidade-desonestidade, cordialidade-grosseria, justiçainjustiça, preguiça-presteza, mesquinhez-generosidade, transgressãoobediência). Referem-se a problemas inerentes ao desenvolvimento, tais como o afastamento em relação aos pais, a rejeição, a disputa entre irmãos, a responsabilidade de assumir compromissos, fazer promessas etc e, enfim, a

\footnotetext{
Não me interessa aqui indagar se as origens dessa epidemia devam ser pesquisadas na política, na ideologia, na uniformidade burocrática, na homogeneização dos mass-media ou na difusão acadêmica de uma cultura média. O que me interessa são as possibilidades de salvação. A literatura (e talvez somente a literatura) pode criar os anticorpos que coíbam a expansão desse flagelo lingüístico." (CALVINO, Italo. Seis propostas para o próximo milênio. p. 72 )

1 "Como educador e terapeuta de crianças gravemente perturbadas, minha tarefa principal foi a de restaurar um significado na vida delas. Para mim este trabalho deixou claro que se as crianças fossem criadas de um modo que a vida fosse significativa para elas, não necessitariam de ajuda especial. Fui confrontado com o problema de deduzir quais as experiências na vida infantil mais adequadas para promover sua capacidade de encontrar sentido na vida; dotar a vida, em geral, de mais significados. Com respeito a essa tarefa, nada é mais importante que o impacto dos pais e outros que cuidam da criança; em segundo lugar vem nossa herança cultural, quando transmitida à criança da maneira correta. Quando as crianças são novas, é a literatura que canaliza melhor este tipo de informação.” (BETTELHEIM, Bruno. A psicanálise dos contos de fadas, p. 12)

${ }^{2}$ Sobre a riqueza deste universo num contexto educacional, cito Regina Machado: “(...) a experiência de aprendizagem (...) precisa do exercício da imaginação para que deixe de ser repetição mecânica de conceitos e técnicas e se forme, ao longo do tempo, como totalidade plena de significação. $\mathrm{O}$ conto de tradição oral oferece ao professor de arte o contato com uma obra de arte de tempos imemoriais em que a imaginação criadora articula valores essenciais dos seres humanos e, ao mesmo tempo, acorda nesse professor suas próprias imagens internas (...)" (MACHADO, Regina. Arte educação e o conto de tradição oral: elementos para uma pedagogia do imaginário) Acredito que os termos "o professor de arte" e "o professor" presentes nesta citação possam ser substituídos por "o ser humano", sem alterar a veracidade das afirmações.
} 
necessidade de encontrar soluções. ${ }^{1}$

Dentre as funções da linguagem escrita, segundo a definição de Ana Teberosky, em seu artigo "Escribir: para qué?"2, privilegiei no presente estudo a função estética - acreditando que o fato de uma pessoa desenvolver-se no que diz respeito a ela influencie positivamente seu desempenho ao fazer uso da escrita para as outras funções.

1 “(...) nada é tão enriquecedor e satisfatório para a criança, como para o adulto, do que o conto de fadas folclórico. $\mathrm{Na}$ verdade, em um nível manifesto, os contos de fadas ensinam pouco sobre as condições específicas da vida na moderna sociedade de massa (...). Mas através deles pode-se aprender mais sobre os problemas interiores dos seres humanos, e sobre as soluções corretas para seus predicamentos em quaisquer sociedades, do que qualquer outro tipo de estória dentro de uma compreensão infantil. (...) Esta é exatamente a mensagem que os contos de fadas transmitem à criança de forma múltipla: que uma luta contra dificuldades graves na vida é inevitável, é parte intrínseca da existência humana - mas que se a pessoa não se intimida mas se defronta de modo firme com as opressões inesperadas e muitas vezes injustas, ela dominará todos os obstáculos e, ao fim, emergirá vitoriosa.” (BETTELHEIM, Bruno. A psicanálise dos contos de fadas. p. 14) Observação: este autor utilizou a denominação "contos de fadas" incluindo contos que, segundo a definição adotada neste trabalho, não se encaixam nesta categoria, mas sim na dos contos maravilhosos - a maioria deles, de magia.

2 Texto avulso em espanhol em que a autora divide as funções da linguagem escrita em extrínsecas (hacia fuera) e intrínsecas (hacia adentro).

As três funções extrínsecas seriam:

1- mnemônica (arquivo e registro; uso da escrita nos domínios da História, da Ciência etc)

2- de regulação e controle social da conduta (leis, normas, direito em geral; identificação/existência social dos indivíduos (documentos); administração; publicidade; censura)

3- de comunicação à distância no espaço e no tempo (conexão entre emissor e receptor da mensagem à distância)

As duas funções intrínsecas seriam:

1- de reificação (distanciamento da mensagem em relação ao próprio emissor)

2- estética (uso criativo da linguagem escrita): “(...) quando aquele que escreve não só reproduz ou imita o uso mais freqüente, mas introduz certas inovações, seja porque combina de forma nova seguindo as mesmas regras, seja porque muda os termos e as regras, então falamos de criação e aparece a função estética. [grifo meu] A materialidade da escrita permite ao escritor voltar-se sobre sua obra para retocá-la, para melhorá-la. Grande parte da literatura, sobretudo alguns gêneros, são impensáveis sem a escrita e sua função estética. Pense-se por exemplo na novela de todo tipo, no drama, em certo tipo de poesia etc." (p. 4 e 5 do referido artigo) A citação é uma tradução livre. 


\section{III- FILIAÇÃo TEÓRICA}

Agora é um momento de falar de amor. Se é que é possível fazer uma divisão clara entre o que é do campo da pedagogia e o que é do campo da psicologia neste trabalho, considero importante revelar quais são as concepções teóricas em uma e outra área que me falam ao coração: na primeira, o construtivismo piagetiano ${ }^{1}$; na segunda, o pensamento winnicottiano. Ou seja, é aquilo com que me identifico e em que procuro balizar minha prática. É claro que isso não quer dizer que eu tenha conseguido sempre ser fiel a meus mestres incorporá-los e digeri-los (tornando-os, de alguma forma, meus) é tarefa de uma vida inteira. ${ }^{2}$ Neste trabalho fiz muitas experiências e o que pude observar só confirmou minha "inclinação" teórica: agora trata-se de discutir erros e acertos, sem perder o humor... Mas já estou adiantando algo que só vem mais à frente, quando teço comentários sobre as oficinas, como se verá.

\footnotetext{
${ }^{1}$ Vale lembrar que "(...) a aplicação de Piaget à prática pedagógica não é imediata e constitui uma tarefa bastante complexa, ainda que compensadora.” (MACEDO, Lino de. Ensaios construtivistas. p. 45)

2 "O público busca explicações ou algo que o instrumentalize para enfrentar problemas de sua prática. O professor aceita a tarefa, apesar de sua "impossibilidade". O autor funciona como o que abre e fecha, isto é, como o que limita, e que, por isso, cria uma possibilidade. As circunstâncias vão configurando uma troca, uma interação. Ou seja, como na vida, tudo são ensaios de construção." (MACEDO, Lino de. Ensaios construtivistas. p. XVIII)
} 


\title{
IV- CONSIDERAÇÕES SOBRE O CRIAR
}

\author{
Definição de criatividade
}

Seja qual for a definição a que cheguemos, ela deve incluir a idéia de que a vida vale a pena - ou não - ser vivida, a ponto de a criatividade ser - ou não - uma parte da experiência de vida de cada um.

Para ser criativa, uma pessoa tem que existir, e ter um sentimento de existência, não na forma de uma percepção consciente, mas como uma posição básica a partir da qual operar.

Em conseqüência, a criatividade é o fazer que, gerado a partir do ser, indica que aquele que é está vivo. Pode ser que o impulso esteja em repouso; mas, quando a palavra "fazer" pode ser usada com propriedade, já existe criatividade. (WINNICOTT, Donald W. Tudo começa em casa. p. 31)

Já que está presente desde o título deste trabalho a palavra "criatividade", quero deixar clara a minha concepção do que seja criar. ${ }^{1}$

Acredito que um conjunto de atividades como o proposto neste trabalho possa propiciar um lidar com diversas formas de comunicação de maneira ativa, de modo que o participante ocupe não somente o lugar de "ouvinte", mas também o de "falante", voltando à comparação feita por Emília Ferreiro. Ainda nesta alegoria, a criação seria o discurso espontâneo, de opinião - mesmo que esta tenha sido composta a partir do que se ouviu de outros. Não pretendo discutir aqui o limiar entre o que se cria e o que se copia. Considero que criar, neste contexto específico, é dar vazão e forma a algo que advém do que habita dentro, onde é simples potencial. A partir do momento em que este "algo" se expressa na forma de uma idéia que pode virar texto, gesto, desenho, objeto etc, estamos criando. O que habita dentro são as experiências vividas (desde a concepção, talvez) e "interagidas", ou seja, tudo o que foi assimilado pelo sujeito, compondo um amálgama peculiar. Criar é, então, inventar soluções particulares para uma determinada situação. Se a situação é a escrita de um texto, este será considerado tanto mais criativo quanto menos comuns ou mais surpreendentes (mais particulares, peculiares) forem as soluções encontradas. Mas a "criatura",

\footnotetext{
${ }^{1}$ Verbete: criar

[Do lat. creare.]

V.t. d.

2. Dar origem a; gerar, formar: A insalubridade cria germes.

3. Dar princípio a; produzir, inventar, imaginar, suscitar: criar uma filosofia, uma religião; "Smetana, todos o sabem, criou a música nacional dos tchecos." (Walter Benevides, Compositores Surdos, p. 45).

(BARROSO, Márcio E. G. - Dicionário Aurélio Eletrônico)
} 
por mais que possa ser parecida com isto ou aquilo, está relacionada a esse amálgama peculiar que constitui seu "criador". 1

Cristina D. Allessandrini compara o pensar criativo à fecundação. ${ }^{2}$ No caso da criação de textos, pode-se seguir adiante nesta alegoria: num momento de gozo criativo, ocorre a fecundação, a concepção de uma idéia. Transformá-la em texto é um parto nem sempre tranqüilo. Depois, é preciso cuidar, alimentar, acompanhar, "dar umas cortadas" - para que o bebê-texto possa crescer e tornarse maduro. Isso dá trabalho e tem momentos de muito prazer alternados com momentos de dificuldade e até desespero.

Gosto dessa alegoria. A concepção (no sentido literal), no entanto, não é possível para todos. No caso dos humanos, somente mulheres podem ser fecundadas e mesmo assim nem todas. Por isso, aproveito o fato de estar no Instituto de Psicologia, onde é comum falar de sexo e também de fezes, para referir-me a uma outra alegoria que certamente pode encontrar ressonância na experiência cotidiana de qualquer pessoa: criar é evacuar. É processar coisas nas entranhas, realizar trocas com elas, depois conferir-lhes uma forma peculiar (diretamente relacionada a essas entranhas específicas, num dado momento) e devolver ao mundo o produto desse processo. Pode-se argumentar que as fezes são dejetos, algo que o organismo não mais aproveita - no que seria diferente do produto de outras criações. Mas ainda aqui vejo mais semelhanças que diferenças. Sabemos que, numa perspectiva macro, as fezes fertilizam o mundo. São tóxicas se permanecerem dentro do organismo. ${ }^{3}$

Quem não consegue expelir suas fezes fica literalmente "enfezado", sente-

\footnotetext{
1 “(...) escrever significa buscar em nosso interior o repertório de experiências de vidas - nossas e dos outros - e de situações que temos, para reelaborá-las, gerando um ato criador, que é relatar essas vivências (ou elementos delas, adaptados a um novo contexto), reorganizadas numa mensagem nossa." (LIMA, Edvaldo Pereira. Da escrita total à consciência planetária. In: Criatividade e novas metodologias. p. 65)

2 "Pensar criativamente é trabalhar a partir do que há de mais nobre em uma pessoa. É a "fecundação". A cada minuto, algo nasce e se transforma. O pensamento emerge e precisa ser refeito, re-elaborado. (...) É o trabalho de aperfeiçoamento e de tematização de conteúdos expressos simbolicamente." (ALLESSANDRINI, C. D. Oficina Criativa e Psicopedagogia. p. 35)

3 "(...) o nosso corpo é feito justamente para deixar sair, e assim evitar qualquer doença. (...) Aquela tensão na nuca é um excesso que tem que sair. Aquele ideal vibrando no peito um dia tem que sair. Talentos abandonados e apetites mal satisfeitos acabam virando doença.

Quando não se deixa sair, o final mais provável é o hospital. Por isso é que praticamente todo mundo tem seguro médico-hospitalar, já que pode ficar doente a qualquer momento, e doença é despesa. Só que, como dizia Gandhi, a multiplicidade de hospitais não é sinal de civilização, é sintoma de decadência. (...) Olho
} 
se mal - elas só se tornam realmente úteis se retornarem à terra. E não se pode dizer o mesmo da criação? Não é exagero afirmar que tudo o que é processado tem de ser, de alguma forma, devolvido ao mundo. Uma grande parte das doenças neuróticas e psicóticas está diretamente relacionada a diferentes níveis de impossibilidade de um fazer criativo. Há um sentido de compartilhar na criação que é praticamente inerente a ela. No caso da criação literária, as palavras de Samir Meserani em uma aula ilustram isso muito bem: "Quem escreve precisa de "sozinhez", mas não de solidão. Estamos sozinhos no momento de criar um texto, mas assim que ele fica pronto é preciso ter alguém para quem mostrar." Talvez isso denote um impulso natural de oferecer o produto de nossa criação como possibilidade de fertilização.

Qualquer pessoa pode dar testemunho da angústia de não conseguir produzir alguma coisa; por exemplo, ter mil idéias ótimas mas nunca conseguir executá-las. Por outro lado, também não faltarão testemunhas do prazer que há em concluir uma tarefa, terminar um trabalho (como uma dissertação de mestrado, por exemplo...). O prazer é grande, mesmo que a tarefa não exija um alto grau de inventividade. Em geral se mistifica a experiência criativa e não se percebe o quanto se pode criar no cotidiano. Não quero dizer que todos sejamos iguais do ponto de vista da capacidade criativa. Mas certamente qualquer ser humano pode sentir-se orgulhoso ao perceber que descobriu uma boa solução para o que quer que seja: arrumar um armário, preparar uma comida, escrever um texto, chegar a algum lugar por um caminho melhor do que o habitual, confeccionar um objeto de arte... ${ }^{1}$ Ou, para voltar à alegoria das fezes: quem nunca sentiu o desconforto de não conseguir evacuar? E o grande prazer de perceber que fez um cocô "saudável"?

Mais uma semelhança: as fezes podem ser usadas para agredir, como na música de Chico Buarque "Geni e o zepelim". As criações também. Haja vista o que se investe em tecnologia bélica ou os vírus que atacam computadores,

\footnotetext{
vivo: a saída é a saúde." (HIRSCH, Sonia. Deixa sair. p. 7)

${ }^{1} \mathrm{O}$ fato é que as pessoas não deveriam assumir trabalhos sufocantes - ou, se não podem evitá-lo, precisam organizar seus fins de semana de modo a alimentar sua imaginação, mesmo nos momentos de rotina entediante. (...)Em algum lugar do esquema de coisas pode haver um espaço para que alguém viva criativamente. Isso envolve preservar algo de pessoal, talvez algo de secreto, que é inconfundivelmente você mesmo. (Idem. p. 34)
} 
desenvolvidos por mentes brilhantes e psicopatas. A capacidade de criar pode ser usada para o bem ou para o mal. Só para lembrar que essa capacidade, por si só, não garante a saúde - se tomarmos o termo em seu sentido mais amplo.

Para Winnicott, a potencialidade simbólica, equivalente à potencialidade para criar e alucinar, é inerente ao ser humano. Ao nascer, a criança recebe da mãe e do ambiente um primeiro repertório para criar: a mãe (se ela o permitir) será a primeira criação do bebê. Cabe a ela proporcionar um "ambiente suficientemente bom", dando a ele, a princípio, "a ilusão de que existe uma realidade externa correspondente à sua própria capacidade de criar."1 Isto é fundamental para que o bebê possa se inscrever no mundo, apropriando-se de sua capacidade de criar: cerne do aparelho psíquico, diretamente relacionada à possibilidade de ser. Assim, é fundamental que o bebê encontre um lugar intermediário entre si mesmo e sua mãe, entre a realidade psíquica interna e a realidade externa - o espaço potencial -, um campo no qual possa constituir seu self. Neste campo - lugar intersubjetivo do nascimento dos símbolos - ocorrem os chamados fenômenos transicionais, que "representam os primeiros estádios do uso da ilusão, sem os quais não existe, para o ser humano, significado na idéia de uma relação com um objeto que é por outros percebido como externo a esse ser."2 É aqui que aparece o objeto transicional: "Ele representa a transição do bebê de um estado em que este está fundido com a mãe para um estado em que está em relação com ela como algo externo e separado." É um ursinho, travesseiro, cobertor ou outro objeto, revestido de importância especial, do qual a criança se desapega aos poucos, na medida em que vai aceitando a realidade externa - sem que deixe de existir, no entanto, por toda a vida, um espaço de ilusão, que se exprime, por exemplo, na arte e na

\footnotetext{
1 “A mãe, no começo, através de uma adaptação quase completa, propicia ao bebê a oportunidade para a ilusão de que o seio dela faz parte do bebê, de que está, por assim dizer, sob o controle mágico do bebê. (...) A tarefa final da mãe consiste em desiludir gradativamente o bebê, mas sem esperança de sucesso a menos que, a princípio, tenha podido propiciar oportunidades suficientes para a ilusão. (p. 26) ... A adaptação da mãe às necessidades do bebê, quando suficientemente boa, dá a este a ilusão de que existe uma realidade externa correspondente à sua própria capacidade de criar. (p. 27) ... Presume-se aqui que a tarefa de aceitação da realidade nunca é completada, que nenhum ser humano está livre da tensão de relacionar realidade interna e externa, e que o alívio dessa tensão é proporcionado por uma área intermediária de experiência (cf. Riviere, 1936) que não é contestada (artes, religião, etc). Essa área está em continuidade direta com a área do brincar da criança pequena que se 'perde' no brincar.” (p. 29) WINNICOTT, Donald W. O brincar e a realidade.

${ }^{2}$ WINNICOTT, Donald. O brincar e a realidade. p. 26)
} 
religião. ${ }^{1}$ A criança articula-se então por imagens, gestos, inscrevendo-se no mundo não somente pela palavra, mas também apresentando seu self através de um ritmo particular, que deve ser reconhecido e respeitado ${ }^{2}$. Prossegue no processo de aceitação da realidade externa, conservando seu espaço de ilusão e desenvolvendo uma relação criativa com a vida. No entanto, se a adaptação da mãe não é suficientemente boa ou deixa de sê-lo precocemente, frustrando o bebê dessa ilusão, a criança tende a desenvolver uma atividade intelectual que tem como objetivo defender-se e suprir essa falta, constituindo então um self dissociado. ${ }^{3}$ Neste caso, a capacidade para criar fica comprometida, pois o fazer não se origina no ser, já que o self verdadeiro está "camuflado" sob o falso self. A pessoa tem então uma sensação de que a vida não vale a pena. ${ }^{4}$

No "método ativo" de Piaget ${ }^{5}$, é de fundamental importância o tema "criatividade". Método ativo está relacionado a interesse, envolvimento, entrega, espontaneidade, criatividade. Dar aulas conforme este método implica em proporcionar aos alunos oportunidade de aprender a partir de experiências de interação verdadeira e significativa com o "objeto de estudo": o sujeito participa do

\footnotetext{
1 "Estou, portanto, estudando a substância da ilusão, aquilo que é permitido ao bebê e que, na vida adulta, é inerente à arte e à religião, mas que se torna marca distintiva de loucura quando um adulto exige demais da credulidade dos outros, forçando-os a compartilharem de uma ilusão que não é própria deles. Podemos compartilhar do respeito pela experiência ilusória, e, se quisermos, reunir e formar um grupo com base na similaridade de nossas experiências ilusórias. Essa é uma raiz natural do agrupamento entre seres humanos." (WINNICOTT, Donald. O brincar e a realidade. p. 15)

2 "A questão da ritmicidade presente em quase toda a obra de Winnicott se relaciona diretamente com os fenômenos que ele chamou de transicionais. O que seria a transicionalidade senão um ritmo de vaivém entre a criança e a mãe, entre a criança e o objeto que a substituirá, entre o analista e seu paciente, entre o criador e sua obra de arte? É por tudo isso que o transicional irá se relacionar diretamente com o brincar e com as atividades culturais, pois ele é o próprio pulsar da vida que contém desde os ritmos biológicos próprios de cada um de nós até os ritmos vários que se originam entre dois seres em relacionamento." (MELLO FILHO, Julio de. O ser e o viver: uma visão da obra de Winnicott )

3 "A mãe que não reage, isto é , cujo rosto é fixo acostuma seu bebê a olhar e não ser visto. As consequiências desse fracasso materno são, primeiro, o paulatino atrofiamento da capacidade criativa da criança e, na sequiência, a formação de uma série de mecanismos de defesa que Winnicott denominou falso self. (...) sucede que desde muito cedo o bebê começa a desenvolver um esforço de compreeensão e, mais do que isso, de previsão das possíveis reações da mãe, com a finalidade de se defender de eventuais ataques percebidos como muito ameaçadores." (ROSA, Sanny S. da. A dissociação do self e suas implicações na educação. Revista Percurso, n. 17, $2^{\circ}$ semestre de 1996, p. 76)

4 "É através da apercepção criativa, mais do que qualquer outra coisa, que o indivíduo sente que a vida é digna de ser vivida. Em contraste, existe um sentimento de submissão com a realidade externa, onde o mundo e todos os seus pormenores é reconhecido apenas como algo a que ajustar-se ou a exigir adaptação. A submissão traz consigo um sentido de inutilidade e está associada à idéia de que nada importa e de que não vale a pena viver a vida." (WINNICOTT, Donald. O brincar e a realidade. p. 95)

5 As afirmações sobre o "método ativo" de Piaget correspondem a anotações feitas em aulas do professor Lino de Macedo no curso "Os métodos de investigação de Piaget e sua importância na Psicologia e na Educação", ministrado neste instituto no $2^{\circ}$ semestre de 1997.
} 
processo, dialogando com o objeto no momento em que aprende. Também no artigo $O$ trabalho em equipes na escola Piaget refere-se à importância do "fazer ativo" no processo de aprendizagem, salientando que o contexto mais favorável para isso é o do trabalho em equipes. ${ }^{1}$ Estes aspectos puderam ser claramente observados ao longo do trabalho que desenvolvi; aponto-os neste texto na forma de comentários entremeados no relato das oficinas, como se verá.

Sanny Silva da Rosa sugere, parodiando Winnicott, que apenas um professor "suficientemente bom" é capaz de um "fazer pedagógico autêntico": aquele que leva em conta o ser do aluno, as suas necessidades. Então, um "fazer pedagógico autêntico" favorece o "fazer ativo" da criança, defendido por Piaget, e este fazer seria igualmente "autêntico", originado num self não dissociado, já que é um fazer entregue, envolvido, carregado de sentido. Imagino que um professor winnicottiano agradaria a Piaget e/ou um professor construtivista agradaria a Winnicott. A experiência que tive nas oficinas alimenta esta hipótese.

\footnotetext{
1 “A tarefa principal da educação intelectual parece, pois, cada vez mais, a de formar o pensamento e não a de enriquecer a memória. (...) Com efeito, a verdade, como todo bem moral, não se conquista senão pelo esforço livre e o esforço livre na criança tem por condição natural a colaboração e o mútuo auxílio." (PIAGET, Jean. O trabalho em equipes na escola. p. 4)

${ }^{2}$ (ROSA, Sanny S. da. A dissociação do self e suas implicações na educação. Revista Percurso, n. 17, $2^{\circ}$ semestre de 1996, p. 76)
} 


\section{V- Metodologia e Resultados}

\section{V.1- SUJEITOS}

Seis crianças com idade entre nove e onze anos - Celso (21/08/86), Gabriela (15/09/86), Graziela (15/06/87), Maiara (22/11/86) Pedro (14/12/86) e Talita (13/04/87), cursando segundo e terceiro ciclos (terceira à quinta série) numa escola pública de São Paulo.

\section{V.2- MATERIAL}

Papel, lápis preto e de cor, canetas hidrográficas e esferográficas, materiais plásticos variados (papel crepom, tesoura, cola, sucata etc), filmadoras e fitas de vídeo, livros e contos previamente selecionados.

\section{V.3- LOCAL}

Todos os procedimentos foram realizadas na escola onde as crianças (sujeitos) estudam, em uma sala que se encontrasse disponível. Utilizamos uma mesma sala de aula durante o primeiro semestre de 1997; depois mudamos para uma sala de reuniões.

\section{V.4- PROCEDIMENTOS}

\section{V.4.a) Sobre leitura e produção de textos nesta escola}

Antes de iniciar o "estudo prévio", fiz uma entrevista com a coordenadora do segundo ciclo, a fim de tomar conhecimento de como eram as atividades de leitura e produção de textos realizadas na escola. Também falaram a esse respeito em entrevistas as professoras das crianças.

Segundo a coordenadora do segundo ciclo (terceira e quarta séries), as situações em que as crianças têm contato com histórias na escola são: 
- hora do conto na biblioteca uma vez por mês, mais ou menos

- retirada semanal de livros (leitura não obrigatória), com os quais cada professor propõe um trabalho: contar a história lida para os colegas, desenhar, resumir etc (o trabalho é feito em casa e apresentado em classe).

- ida à biblioteca acompanhada pela professora, para leitura individual

- leitura de livros que constam da biblioteca de classe (composta por livros que as crianças trazem de casa somados a livros distribuídos pelo governo)

- leitura de livros específicos recomendados pelo professor, a partir dos quais são desenvolvidos trabalhos diferentes (mais ou menos um por bimestre)

- trabalhos em grupo a partir de livros que tratam de temas específicos, como por exemplo "disciplina"

- leitura de livros pelo professor em classe (principalmente no primeiro ciclo)

- paráfrase criativa de determinados textos

- criação de histórias a partir de uma idéia contida num texto lido

- criação de um texto a partir de um tema pesquisado

As entrevistas com as professoras foram feitas no final de 97, quando eu ainda não tinha certeza se daria continuidade às oficinas em $98 .{ }^{1}$

Quanto às propostas de redação feitas em classe no ano de 1998, a professora de Celso, Maiara, Pedro e Talita (P1) trabalhou basicamente com paráfrase em suas duas formas: reprodutiva (ou seja, escrita de um texto com outras palavras) e criativa (utilização de um texto como base para escrita, sem o compromisso de se manter fiel a ele, seja na forma ou no conteúdo) ${ }^{2}$. Pedia muitas vezes que escrevessem "alguma coisa", deixando em aberto o quê ("tema livre"): narrativas de histórias vistas em vídeo ou cinema, capítulos de novela de $\mathrm{TV}$, relatos de acontecimentos quaisquer etc.

Chamou-me a atenção seu comentário sobre criação, segundo o qual parece não acreditar que as crianças sejam muito capazes de inventar histórias.

1 Agrupei estes dados sob este item por uma questão de "afinidade temática", embora tenham sido colhidos em momentos tão diferentes. Hoje penso que teria sido interessante entrevistar as professoras antes e depois da realização das oficinas.

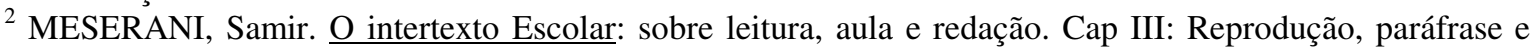
criação. 
(Será precipitado dizer que este pode ser um terreno fértil para o fenômeno de "profecia auto-realizadora"1? Os textos das crianças confirmam a crença de suas professoras de que elas "só sabem" fazer paráfrase ou isto acontece em função dessa crença?)

Segundo a professora de Gabriela e Graziela (P2), a ênfase do trabalho com redação em sala de aula recaiu sobre os tipos de textos - jornalístico, informativo, poético, narrativo. "A gente procura enfatizar a estrutura do texto: pontuação, principalmente pontuação de diálogo, ortografia, coesão, coerência, a gente vai enfatizando todos os pontos." Disse explorar o aspecto "coerência" com base em leituras, "interferindo para que eles apliquem na escrita". ${ }^{2}$ A redação era proposta como atividade de fechamento de várias atividades com base em uma determinada leitura: uma "reescrita", às vezes mudando a forma, de poética para narrativa ou o inverso, conforme o tipo de texto em questão. Quando interroguei sobre produção de textos inventados pelas próprias crianças, P2 afirmou que raramente dá redação com "tema livre", dizendo a seguir que ou se trabalha com base num determinado texto, ou com um tema dado - por exemplo, uma data comemorativa, um acontecimento importante etc. Tanto na entrevista com P1 quanto com P2, pareceu-me que há uma certa confusão entre "criação" e "tema livre" - quando se pergunta sobre histórias inventadas pelas crianças, elas imediatamente pensam numa proposta sem nenhum parâmetro.

Observei que há uma certa distância entre o discurso da coordenadora e o das professoras, ou seja, parece haver uma diferença entre o que se planeja e se propõe em reuniões de orientação e o que se passa de fato dentro das salas de aula. Isto é de particular interesse para este trabalho, pois a principal diferença que notei refere-se justamente à expectativa em relação à possibilidade de os alunos criarem, inventarem coisas para escrever. A coordenadora parece dar importância e até mesmo uma certa ênfase a este tipo de atividade, enquanto uma das professoras expressou claramente a concepção de que os alunos nessa

\footnotetext{
1 "efeito das expectativas do professor sobre o desempenho de seus alunos" (OTTA, Ema; LEME, Maria Alice V. S.; LIMA, Maria da Penha P.; SAMPAIO, Sonia Maria R. Profecias auto-realizadoras em sala de aula: expectativas de estudantes de Psicologia como determinantes não-intencionais de desempenho. Revista Psicologia, ano 9, número 2, julho de 1983, p. 27)

$\frac{2}{2}$ Infelizmente neste momento não fui adiante, insistindo em saber exatamente como era feita essa interferência.
} 
idade não têm muitas condições de criar. ${ }^{1}$

Trechos das entrevistas encontram-se no anexo 19.

\section{V.4.b) “Estudo prévio"}

Realizou-se no segundo semestre de 1996 (entre 17/10 e 12/12) o que seria um estudo prévio, ou seja, uma "ensaio", anterior ao início das oficinas propriamente ditas. "Seria" porque acabou se tornando um primeiro bloco de oficinas, uma vez que optei por seguir adiante com as mesmas crianças. Havia um projeto de realizar oficinas com mais um grupo, mas a grande maioria faltou aos três encontros que chegaram a ser marcados e acabei reconsiderando essa necessidade.

Este primeiro bloco consistiu em oito oficinas, nas quais experimentei diferentes tipos de atividades, porém não de forma tão organizada como a partir de 97. Procurarei relatá-las de forma resumida.

As atividades realizadas nos três primeiros encontros consistiram basicamente em "conversas" sobre personagens e consulta a livros com gravuras. Contei e li algumas histórias. Em vários momentos, procurei ensinar conceitos como "foco narrativo" e outros aspectos do texto, mas percebi que tais discussões (ou “discursões"...) simplesmente não faziam o menor sentido para as crianças. Elas ficavam dispersivas, desatentas. Cheguei a conversar sobre isso com elas, pedindo sugestões e perguntando por que elas achavam que estava tão difícil prestar atenção. De forma alguma localizavam o problema na minha ação, no que eu propunha; procuravam atribuir o fracasso da atividade a si mesmas ("Eu estou muito cansada."; "Fulano fica bagunçando.") ou às condições do ambiente ("É melhor sentar nas carteiras em vez de ficar em roda no chão.") ${ }^{2}$. Na quarta

\footnotetext{
${ }^{1}$ Vale comentar aqui que esta expectativa depende muito da concepção que se tenha sobre o criar. De meu ponto de vista, considero importante levantar junto às crianças o tema da intertextualidade, mostrando a elas que há elementos comuns em diferentes histórias e que não há problemas em utilizar em seu próprio texto uma idéia contida numa história existente. No entanto, penso ser igualmente importante ter cuidado com a forma como se pontua este aspecto, estimulando sempre a criança a encontrar formas pessoais para aproveitar uma idéia que não é sua. Digo isto porque me preocupa um pouco que esse conceito acabe se tornando um encorajamento à simples paráfrase - equívoco que já tive chance de testemunhar. Isto constitui, a meu ver, uma desvalorização do potencial criativo das crianças e um desestímulo à inventividade.

${ }^{2}$ As respostas delas são de especial interesse para a discussão deste trabalho, como se verá adiante, nos comentários sobre as oficinas e também no último capítulo. Aproveito a oportunidade para lembrar que,
} 
oficina, propus a criação de um personagem humano (a maioria falou de si próprio...) a partir de uma ficha contendo algumas indicações como "nome, onde mora, o que faz, quantos anos tem, comida de que mais gosta" etc. Na oficina seguinte, novamente inventaram-se personagens, mas de forma mais livre: algumas crianças criaram personagens humanos; outras, personagens fantásticos. Na outra oficina, fizemos uma roda e procuramos colocar todos os personagens num mesmo contexto, estabelecendo relações entre eles. ${ }^{1}$ Havia uma intenção de que cada criança utilizasse as idéias que haviam surgido no grupo para a criação de um texto próprio - o que de fato chegou a ser iniciado, na penúltima oficina, porém não houve tempo para que cada criança chegasse ao fim de sua história. Já estávamos em dezembro, em pleno clima de férias... Decidi não retomar a história e encerramos o trabalho do semestre com uma oficina em que levei pela primeira vez material plástico, para que confeccionassem chapéus de fadas e magos e varinhas de condão. Li uma história e sorteamos amigo secreto; depois todos quiseram brincar de "teatrinho", aproveitando o fato de haver na sala um teatro de fantoches. Nesse dia ficou claro o quanto é estimulante e importante, para as crianças, o "fazer" significativo e o brincar.

\section{V.4.c) As Oficinas de Redação e Criatividade}

Foram sorteadas seis crianças de uma série (período da tarde), dentre as que demonstraram interesse em participar das oficinas, anunciadas como "aulas de redação", em regime extracurricular, no período da manhã. Realizaram-se vinte e cinco oficinas; sete no primeiro e sete no segundo semestre de 1997; onze no primeiro semestre de 1998. As oficinas realizadas no primeiro semestre de 97 tiveram duração de duas horas; no segundo semestre do mesmo ano este tempo foi reduzido para uma hora e meia, por se considerar que seria tempo suficiente.

\footnotetext{
mesmo sendo muitas vezes interessante levantar junto aos alunos esse tipo de discussão, é de responsabilidade do professor avaliar as atividades que propõe. A criança reage a elas; nós é que temos de interpretar essa reação. Ainda mais porque estão muito acostumadas a ser culpadas pelo fracasso de atividades escolares, quando estas é que estão sendo propostas de uma forma inadequada: "A escola tradicional desejou prontamente iniciar a criança nas leis do mundo exterior por meio da aquisição verbal dos conhecimentos que a ela se relacionam: isto, sem o exercício da própria inteligência em seu trabalho ativo de adaptação." (PIAGET, Jean. Métodos pedagógicos e fins culturais. p. 101)

${ }^{1}$ Aprendi esta técnica no curso de Criação Textual de Samir Meserani.
} 
Em 98, tivemos de reduzir o tempo ainda mais, pois duas crianças haviam mudado de período, de modo que o único horário em que era possível reunir todo o grupo era entre 12:00h e 13:00h. ${ }^{1}$ Realizaram-se diferentes atividades, sendo que nem todas aconteceram em cada uma das oficinas. Nos próximos sub-itens, as atividades serão explicadas.

\section{V.4.c.i) Sobre as atividades}

Nas oficinas, eram propostas diferentes atividades, que podem ser assim agrupadas:

- Atividades corporais

- Exploração do tema do dia

- Estimulação da criatividade

- Produção escrita

A divisão em itens tem somente efeito didático, já que na prática o limiar entre alguns tipos de atividades não é tão preciso. Por exemplo: ao explorar o tema do dia, também se está estimulando a criatividade, o que também acontece em muitas atividades corporais e vice-versa (em algumas atividades de estimulação da criatividade se usa o corpo em movimento) etc.

Além disso, vale notar que esse agrupamento em quatro itens resultou de uma análise dos dados feita a posteriori, somente com o intuito de facilitar a explicação de como eram as atividades, em que consistiam, em que se fundamentavam - o que será feito a seguir. Na prática, havia um planejamento; no entanto, este não era rígido e muitas vezes as oficinas resultavam ser muito diferentes do que estava previsto, tomando um novo rumo, balizado na interação das crianças com as atividades e em idéias e sugestões que partiam delas mesmas.

As atividades propostas nas oficinas derivam do conjunto de minhas

\footnotetext{
${ }^{1}$ Acredito que a duração ideal de cada oficina seria de uma hora e quinze minutos a uma hora e meia. Apenas uma hora, com certeza, é muito pouco. A necessidade de fazer um intervalo pode variar, conforme o tipo de atividade e a disposição das crianças; de forma geral, considero importante contar com um tempo de mais ou
} 
experiências pessoais com escrita, aprendizagem de forma geral, Psicologia e corpo $^{1}$. Ou seja, escolhi, em meu repertório vivenciado, atividades que me pareciam fazer sentido para o que eu pretendia desenvolver com as crianças, e experimentei aplicá-las. Tendo em mãos esse "balaio de ferramentas" (que procurei adaptar a um público infantil), tracei as linhas mestras do projeto, definindo as diretrizes básicas (queria trabalhar com os contos populares explorando alguns personagens ${ }^{2}$ neles presentes e a estrutura de sua narrativa), e meus objetivos, como já foi exposto. Então, conforme a participação das crianças em cada atividade, avaliava o que "dava certo" e o que não dava e definia o "tema do dia" da próxima oficina, dando continuidade ao que tinha acontecido no encontro anterior. Além disso, a própria experiência oficina a oficina fornecia elementos para a criação de novas atividades. É claro que agora, tomada uma certa distância dos fatos (no famoso aprés-coup), é possível avaliar com mais clareza o quanto cada atividade foi produtiva ou não - análise na qual determe-ei mais adiante.

\section{Atividades corporais}

A escolha de propor, geralmente no início de cada oficina, diferentes atividades corporais tem o propósito de trazer a presença integral de cada criança. O indivíduo presente em seu corpo está alerta e atento, portanto dono de si e de seu potencial criativo. Esta idéia está relacionada a uma visão de ser humano segundo a qual a cisão entre corpo e mente - uma tendência em nossa cultura - não contribui para uma experiência significativa do que quer que seja:

\footnotetext{
menos dez minutos para fazê-lo.

${ }^{1}$ Formei-me em psicologia na USP. Freqüentei durante vários anos o Laboratório de Psicopedagogia da mesma universidade e fui professora auxiliar durante um ano (alunos de faixa etária entre sete e dez anos). Freqüentei diversos cursos de redação - aos quais referir-me-ei ao falar das técnicas de escrita utilizadas nas oficinas. Fiz um curso de formação em Psicologia Biodinâmica (abordagem neo-reichiana) e diversos cursos de massagem. Atendo em consultório como psicoterapeuta corporal e como massagista e freqüento o curso de formação no Centro Brasileiro de Cadeias Musculares e Técnicas G.D.S. / Escola de Reeducação do Movimento Ivaldo Bertazzo.

2 O personagem ou a personagem: tanto faz. A palavra personagem admite ambos os gêneros: substantivo masculino e feminino, segundo o Dicionário Aurélio Eletrônico (BARROSO, Márcio E. G.). Pode-se usar somente o artigo feminino, mesmo para designar personagens masculinos, ou não. Optei por flexionar o artigo conforme o gênero do personagem, simplesmente por ser este o uso mais frequiente no cotidiano. E, quando se trata de uma designação genérica, uso o artigo masculino. Por exemplo: "Qual é o personagem do qual você mais gosta nesta história? A princesa ou o príncipe?”
} 
tanto a aprendizagem como o simples estar no mundo. Isto não quer dizer que se esteja defendendo a idéia de que a única forma de trazer a presença integral das crianças seja propondo atividades explicitamente corporais, já que há outras formas de presentificar um "fazer ativo" (antes, trata-se apenas de uma escolha, entre muitos possíveis, que está relacionada à minha formação profissional ligada ao corpo). Isto se observa, por exemplo, no jogo de regras. O próprio ato de escrever pode ser também um fazer ativo.

De qualquer forma pode-se dizer, sem o risco de exagerar, que é muito clara a importância do fazer para a criança. Melhor dizendo, para a criança ele é vital, assim como o movimento. $O$ adulto consegue ignorar essa necessidade de movimento, de utilização do corpo, mas é também bastante claro o prazer que pode tirar de atividades como a dança, por exemplo (não somente a dança profissional), na qual é preciso estar presente de "corpo e alma", em movimento. ${ }^{1}$

Procurou-se também desenvolver atividades que de alguma forma requisitassem a criatividade das crianças - por exemplo, criar ritmos batendo os pés ou as mãos, inventar seqüências de movimentos coordenados de pés e mãos que os outros deviam repetir ("desafios"), imaginar uma bola nas mãos e passá-la a um colega, adequando os gestos ao peso e volume virtuais do objeto etc. Fora do contexto das atividades corporais propriamente ditas, em alguns momentos também se propôs o uso do corpo todo em movimento, por exemplo para fazer mímica representando um personagem ou posturas corporais representando determinados "estados" correspondentes a diferentes momentos de um conto (equilíbrio, conflito e solução do conflito/felicidade).

Pode-se pensar que não haveria necessidade de propor tal tipo de atividade para as crianças, pois elas já são bastante "corporais". Mas acredito que

\footnotetext{
${ }^{1}$ Sobre a importância do movimento numa perspectiva filogenética, Ivaldo Bertazzo nos diz: "O homem é uma estrutura em pé. Precisou de alguns milhões de anos para se definir como uma estrutura que se mantém em pé. $\mathrm{E}$ chegou a esse estágio em sua evolução por meio do movimento, dos gestos que estruturou para prover sua subsistência e atender a seu prazer. Além de constituir elemento fundamental para definir sua estrutura corporal, o movimento também determinou a constituição de sua psique. O homem, esse "bípede implume", é pois uma estrutura em movimento. Complexificando gradualmente o repertório de movimentos ao longo de sua evolução, chegou a conhecer autonomia, liberdade e ampliou o raio de sua interferência no mundo que o cerca. Seus braços adquiriram independência e se direcionaram no espaço, permitindo às mãos experimentar e trazer esse mundo para si como nenhuma espécie fizera antes. Porém, não só o homem ganhou autonomia através do movimento, mas pode-se dizer que, no decorrer da História, o movimento humano também ganhou autonomia, características próprias, marcas distintivas." (BERTAZZO, Ivaldo. Cidadão Corpo: Identidade e Autonomia do Movimento, p. 31)
} 
isso seja, ao contrário, um ponto a favor: as crianças se expressam muito através do corpo e precisam utilizá-lo. É uma linguagem que as toca, que Ihes diz respeito, que faz sentido para elas.

\section{Exploração do tema do dia}

Levantamento de repertório, informações, leitura ou narração de histórias, consulta a livros com gravuras, utilização de música relacionada ao tema (Oficina 4) etc.

Introdução aos itens "Estimulação da criatividade" e "Produção escrita"

Foram realizadas nas oficinas algumas atividades para despertar a criatividade, estimular a escrita e favorecer a revisão do texto produzido. Algumas delas aprendi em diferentes cursos: Grupo de Criação Textual, com Samir Meserani; Criação e Crítica Textual, com Erson Martins de Oliveira; Escrita Total', com Edvaldo Pereira Lima, sendo que realizei algumas adaptações que julguei necessárias ou interessantes. Outras inventei ou organizei a partir de experiências em contextos diversos e de lembranças da minha própria vivência como estudante, desde as primeiras letras.

\section{Estimulação da criatividade}

- Visualização Criativa: Trata-se de um exercício de imaginação guiado; ou seja, alguns elementos são dados e a pessoa é convidada por um "locutorcondutor" a visualizar algo. Para ajudar, sugere-se imaginar que há uma tela na parte interna da testa, onde vai sendo projetado um filme. Por exemplo, uma conversa com um personagem: de olhos fechados, imaginar um encontro com um personagem. Observar bem como ele é e entrevistá-lo (caso saiba falar...) ou procurar colher o máximo possível de informações a seu respeito. Deixar que ele se manifeste. Pode ser que ele esteja feliz, ou bravo, ou triste... (método Escrita

\footnotetext{
${ }^{1}$ No artigo "Da escrita total à consciência planetária" o autor expõe o método Escrita Total (ver cap.
} 
- Árvore da Criação: Desenhar, de preferência utilizando diferentes cores, "mapas de idéias" em forma de árvore: no meio do papel se desenha uma elipse ou círculo, dentro do qual se escreve uma palavra chave. Esta forma é a representação do tronco da árvore vista "de cima". Do tronco saem os galhos e destes os ramos; nos galhos são escritas palavras que venham à mente a partir da palavra central e assim por diante. (método Escrita Total)

- "Chuva de palavras": Consiste em escrever ou dizer palavras que vierem à cabeça, rapidamente, sem pensar muito.

- Utilização de música: como estímulo a partir do qual se procuram identificar climas, sentimentos etc e associá-los aos momentos do conto (Oficina 11), ou como estímulo paralelo (Oficina 3).

- Trabalhos plásticos: desenho, confecção dos trajes de um personagem com papel crepom, cola e outros materiais (Oficina 2) ; confecção de um objeto com sucata, papel crepom etc que representasse um personagem, por transmitir uma idéia ou sensação que remetesse a ele (Oficina 14).

- Dramatização: representação de personagens; realização de gestos que representassem diversos momentos de um conto (Oficina 8).

\section{Produção escrita}

- Escrita rápida: A técnica consiste em escrever tão rapidamente quanto se possa, durante alguns minutos (doze com adultos; com as crianças adaptei para 5 a 7 minutos). Enquanto não terminar o tempo, não se pode parar, mesmo que seja para continuar escrevendo qualquer coisa. Se houver dificuldade para 
começar, recomenda-se que se escreva qualquer coisa, por exemplo: "Eu não tenho a mínima idéia do que poderia escrever agora, estou sem idéias, mas tenho de escrever e vou escrever qualquer coisa porque a regra agora diz que eu posso escrever qualquer coisa, mas qualquer coisa mesmo, qualquer-qualquerzíssima, absolutamente qualquer... Então eu vou continuar, porque não vale parar e aí quem sabe eu acabo cansando de ficar escrevendo sempre a mesma coisa; quem sabe eu escrevo algo diferente. Diferente. Diferir. Di-ferir. Diferir é ferir duas vezes, ferir duas coisas??? Duas feridas: uma no corpo de Quíron, outra no corpo do doente que o consulta. Quíron cura o doente, mas sua ferida não sara. São feridas diferentes (...)“ E então pode surgir uma idéia a partir da qual são feitas associações; surge um assunto sobre o qual se pode escrever algo. Ao lado da recomendação de escrever rapidamente, aconselha-se que, neste primeiro momento, se deixem de lado as preocupações com gramática e caligrafia, pois estas requisitam o pensamento analítico e portanto atrapalham o fluir criativo. A revisão e edição ficará para um momento posterior. (Tive contato com esta técnica em dois cursos: Criação e Crítica Textual e Escrita Total. Consta também da série Redação Escolar: Criatividade, de Samir Meserani, por exemplo nas $p$. 89 e 113 do volume "Colégio 1")

Observação: Recomenda-se que se escrevam os textos pulando linhas, para facilitar a revisão, uma vez que haverá espaço para puxar flechas, asteriscos, rabiscar à vontade.

- Produção em duplas

- Troca de textos: cada criança lê um texto de um colega

- Discussão em grupo (com todos) ou em duplas dos textos produzidos. As crianças dão palpites sobre os textos dos colegas e ouvem os palpites deles sobre seu próprio texto.

- Depois que o texto foi comentado, é escrito novamente, fazendo-se as alterações necessárias ou desejadas. 


\section{V.4.c.ii) Relato comentado das oficinas}

Neste item apresento um relato de como foram as oficinas, intermeando-o com referências teóricas e comentários sobre a experiência. Para isto, optei por utilizar notas de rodapé, no intuito de preservar o fluxo da narrativa. Comentários são indicados com o símbolo (c) antes do número da nota de rodapé correspondente; da mesma forma, remeto a referências a bibliografia e teoria com o símbolo ${ }^{\circledR}$.

No primeiro semestre de 1997 (oficinas 1 a 7 ) as atividades tiveram como tema central os personagens do universo dos contos de magia e da mitologia grega. Este último universo surgiu no contexto de uma oficina a partir do primeiro (estávamos falando de monstros, na oficina 5) e considerou-se pertinente abordálo. $\AA^{1}$

A escolha do personagem como o elemento da narrativa sobre o qual recairia o enfoque do trabalho realizado nas oficinas do primeiro semestre de 97 deve-se ao fato de este ser um elemento fundamental da narrativa de histórias em geral: o eixo em torno do qual gira a grande maioria delas. Assim, nestas oficinas os seres que habitam os contos de magia foram a principal referência a partir da qual se desenvolveram as atividades. Como anfitriões a nos tomar pela mão e levar-nos para visitar seu mundo: o universo dos contos de magia. $\AA^{2}$

\section{OFICINA 1: BRUXAS, MAGOS, FADAS, ELFOS (15/05/97)}

Introdução: No início, falei um pouco sobre o trabalho que seria realizado, dizendo algo como: "Nos nossos encontros, vamos fazer diferentes tipos de

\footnotetext{
${ }^{1}$ Vale mencionar que conto de magia e mito têm um parentesco histórico: "A pesquisa de Propp é coerente com seu programa. Se já desenvolvera o estudo da estrutura dos contos e o das mudanças dos contos, agora irá desenvolver o estudo das origens, em Las raices historicas del cuento (1946): os elementos do conto serão estudados agora em função de suas fontes. E Propp reconhece duas fases na evolução do conto. Uma primeira, sua pré-história, em que o conto e o relato sagrado - conto/mito/rito - se confundiam. Entende mito no sentido de "relato sobre a divindade ou seres divinos em cuja realidade o povo crê" (p. 30). E rito, tal como costume e segundo Engels, ou seja, como "atos ou ações cuja finalidade é operar sobre a natureza e submetê-la”. (...) Uma segunda fase de que fala Propp é a história mesma do conto, quando ele se libera da religião e passa a ter vida própria. O relato sagrado torna-se profano. Os narradores, antes sacerdotes ou pessoas mais velhas, passam a ser pessoas quaisquer." (GOTLIB, Nádia Batella. Teoria do conto. p. 23-25)

${ }^{2}$ Sobre a terminologia e as características dos contos populares, ver apêndice do item V.4.
} 
atividades: vamos conversar sobre diferentes tipos de personagens, contar o que sabemos sobre eles, aprender coisas novas, ouvir histórias, desenhar, ouvir música, mexer o corpo, escrever, imaginar, inventar histórias..."

Ao som de uma música de tambores, conduzi um exercício de percussão nos ossos: cada um batia com as próprias mãos em seu corpo ("Pensem em 'acordar' os ossos.").

Em roda, sentados no chão, conversamos sobre bruxas, fadas, elfos e magos. Relembramos alguns aspectos vistos no ano anterior e olhamos figuras do livro Magos, Fadas e Bruxas: quase tudo o que você queria saber (PRIETO, Heloisa).

Fizemos então uma "chuva de palavras". Primeiramente as palavras tinham de estar relacionadas a bruxas, depois a fadas etc.

A seguir, as crianças deitaram-se no chão e conduzi um exercício de visualização criativa em que cada criança tinha de imaginar que ia chegar um personagem para visitá-la e procurar observá-lo, conversar com ele, descobrindo suas características: seu nome, do que gostava, não gostava, o que fazia, onde morava etc.

Depois fizemos uma brincadeira de mímica: cada um representava o personagem que tinha "aparecido" na imaginação criativa e os outros tentavam adivinhar qual era. (ํ)

Sentados nas carteiras, cada um escreveu alguma coisa sobre o "encontro". A consignação era livre: podia ser uma descrição do personagem, uma narração do encontro, um poema... "É para escrever o mais rápido possível, sem se preocupar se vai escrever certo ou errado, com letra bonita ou feia." (๑)

\footnotetext{
${ }^{1}$ Este "exercício" não se revelou muito rico, pois as crianças muitas vezes se limitavam a repetir os gestos dos colegas, parecendo um pouco tímidas. Por isso mesmo, fiz apenas uma "rodada", que foi razoavelmente divertida.

${ }^{2}$ As crianças em geral "não acreditavam" que não era preciso se preocupar com a forma, parando às vezes para fazer perguntas sobre ortografia. Chamou-me a atenção esse fato: terá sido porque "quando a esmola é muita, o santo desconfia?" Ou estarão elas tão acostumadas ao medo de errar, que titubeiam diante de uma liberdade concedida?
} 
Fizemos a seguir um intervalo, após o qual li para eles uma história: "O gato, o mago e o príncipe" (ANEXO 1). Enquanto isso, desenharam.

\section{OFICINA 2: ELFOS E FADAS (22/05/97)}

Observação: Maiara, Pedro e Talita faltaram.

Em roda, de pé, jogamos um para o outro uma bola imaginária. Cada um devia imaginar um peso e tamanho e evidenciá-los ao jogar; quem recebia respeitava as características imaginadas pelo outro, mas logo em seguida a bola se transformava e era jogada conforme essas novas características.

Sentados em roda, recordamos a oficina anterior. Comentei que no exercício de imaginação surgiram muitos elfos - personagens menos conhecidos que as fadas e bruxas. Mostrei as gravuras (fadas e outros seres) do livro Lady Cottington's Pressed Fairy Book (JONES, Terry). Surgiu uma discussão a respeito de um tipo de ser que aparecia nas gravuras: seriam elfos? Li uma história em que aparecia um elfo: "A guerra entre o mundo dos homens e o mundo das fadas" (ANEXO 2).

As crianças confeccionaram, em papel crepom, as roupas do personagem que tinha "aparecido" para elas no exercício de visualização criativa da oficina anterior. (C) ${ }^{1}$ Vestidas com essas roupas, seguiram a proposta:

"Você vai imaginar que é um ator que vai representar uma pequena história que aconteceu com esse personagem de sua imaginação, de improviso. Falta pouco tempo para a apresentação começar e o personagem aparece na sua frente. Você pede que ele ou ela conte uma história de algo interessante que aconteceu em sua vida, para que você possa representar no palco."

\footnotetext{
${ }^{1}$ Essa atividade despertou bastante o interesse das três crianças presentes. O único problema foi que acabou sendo um pouco demorada. As meninas queriam caprichar nos detalhes e Celso terminou antes, ficando meio entediado. Procurei então apressar o trabalho das "costureiras" e passar para outra atividade. Considero que poderia ter sido mais proveitoso propor a confecção de um objeto mágico e/ou somente uma peça do vestuário do personagem, como no "estudo prévio": varinha de condão e chapéu (fadas e elfos). Isso fecha um pouco mais a demanda e não deixa margem a que a atividade ocupe muito tempo - o que, de forma geral, acaba ficando cansativo.
} 
Ficaram caminhando e imaginando, às vezes fechando os olhos. Depois de mais ou menos dez minutos, tiraram as fantasias e sentaram-se para escrever: "Escrevam o mais rápido possível a história que o personagem contou pra vocês."

\section{OFICINA 3: FADAS E ELFOS, DUENDES E GNOMOS (05/06/97)}

Conduzi exercícios em que as crianças faziam movimentos elípticos com os pés, depois bacia, em seguida braços e mãos.

Sentados em roda no chão, recordamos as atividades da oficina anterior, contando o que tínhamos feito para os que não haviam comparecido. Mostrei novamente o livro Lady Cottington's Pressed Fairy Book (JONES, Terry) e reabri a discussão: que tipo de ser era aquele das gravuras? Introduzi então os personagens "duende" e "gnomo". Li um texto que conceituava os elementais e esclarecia as diferenças entre eles e os gnomos (ANEXO 3). Concluímos que os seres das gravuras que tinham suscitado a discussão eram duendes.

Então, as crianças que haviam comparecido à oficina anterior mostraram as roupas que haviam confeccionado aos colegas que tinham faltado.

Depois, formaram-se três duplas, sendo que cada uma deveria ter uma criança que tinha comparecido na oficina anterior e outra que havia faltado. Houve protestos, pois as meninas queriam formar outras duplas, mas no fim concordaram com a proposta. Sentaram-se às carteiras e distribuí os textos escritos pelas crianças, propondo a seguinte atividade: tomar o texto feito em escrita rápida e inventar mais coisas, agora com mais tempo e podendo contar com os palpites de um (ou uma) colega. Poderiam também prestar mais atenção à forma, corrigindo palavras escritas incorretamente e caprichando na letra. Numa das duplas, uma garota se recusou a partir da história da colega e disse que queria escrever uma história sua. (c) ${ }^{1}$ Abri então a possibilidade para todos de cada um fazer seu próprio texto, mas as outras duplas preferiram permanecer

\footnotetext{
${ }^{1}$ Tentei argumentar que neste momento a proposta era outra, mas percebi que não era o caso de insistir...
} 
unidas. Observei que as garotas "independentes" permaneceram lado a lado e trocaram idéias.

Relembrei que a atividade consistia em relatar um acontecimento na vida de um personagem. "Pode ser que apareçam também outros personagens, como por exemplo gnomos e duendes".

Coloquei uma música e disse que ficassem por alguns minutos em silêncio, de olhos fechados, pensando no que iam escrever, fazendo somente algumas anotações. Sugeri que prestassem atenção ao tipo de emoção ou sensação que a música despertava neles.

Uma das duplas seguiu a sugestão; outras duas crianças começaram a escrever ou desenhar independentemente e outra dupla ficou discutindo baixinho. Logo mais as três duplas estavam discutindo. Circulei pelas carteiras, fui acompanhando a produção das crianças. A atividade durou aproximadamente meia hora, até o final da oficina. As crianças terminaram o trabalho dentro do tempo disponível e algumas fizeram desenhos.

Contei-Ihes que a música que tinham ouvido se chamava "Sonho de uma noite de verão" ("Sommernachtstraum", de Mendelssohn) - título de uma história de Shakespeare sobre fadas e elfos.

OFICINA 4: MONSTROS (12/06/07)

Em roda, atirávamos, um para o outro, um gato de pelúcia, utilizado como se fosse uma bola. Quem arremessava o gato dizia uma palavra qualquer. A regra era dizer a primeira palavra que viesse à cabeça, rapidamente, sem pensar muito.

Em continuidade à atividade corporal com "chuva de palavras", pedi que adivinhassem qual o personagem de que se ia tratar no dia. Depois que alguém acertou, a brincadeira mudou: as palavras ditas tinham de estar relacionadas aos monstros. Alguém falou "dragão". Depois de um tempo jogando, propus a discussão: "Os dragões são monstros? Todos os dragões são maus? Todos os monstros são maus?" 
As crianças se deitaram no chão para ouvir a música "O monstro", de Luis Tati (ANEXO 4).

Antes de colocar a música uma segunda vez, guiei um "passeio imaginário" pelo próprio corpo: "De olhos fechados, pensem nos seus pés; agora canelas" etc até a cabeça. Algumas crianças tiveram dificuldade em manter os olhos fechados. Uma dupla de meninas ficou dando risadinhas, mas logo sossegou. Depois da segunda audição, conversamos sentados em roda sobre o monstro da música. Comentou-se que ele era medroso, apegado à mãe, que não era mau; nem todos os monstros são maus. Falei da existência de outras histórias, como as lendas chinesas em que dragões eram amigos dos homens.

Deitados novamente, de olhos fechados, convidei-os a um passeio imaginário:

"Vocês vão imaginar que é um domingão de sol. É importante fechar os olhos, pra poder soltar a imaginação. Então é um domingão e vocês vão fazer um passeio com o colégio - vocês podem escolher - ou com os pais de vocês, com os primos. O passeio é ir ao zoológico. Todo mundo aqui já teve essa experiência na vida, né? (Alguém diz que foi ao Simba Safari no "sábado retrasado".) Olha só, então. Só que esse zoológico que vocês estão indo hoje não é tipo Simba Safari, desses em que os animais ficam soltos; os animais estão em jaulas, mesmo. E vocês vão entrando, imaginando que vocês estão chegando no zoológico com as pessoas que estão com vocês. Procurem ver quem está com vocês. Fechem os olhos, imaginem. (Alguém faz um comentário sobre o que está imaginando; digo que não é preciso falar, mas somente imaginar.) Vamos fazer uma coisa, pra facilitar. É lógico que muitas vezes a gente não consegue enxergar exatamente as imagens quando a gente imagina, como se fosse um filme - não é assim. Às vezes até é, mas geralmente o que acontece? - a gente imagina, só; a gente vai imaginando como seria. (Mais alguém comenta sobre o que está imaginando e digo que depois vai haver um momento para cada um falar o que imaginou.) Agora cada um vai ficar com as coisas que está imaginando para si, tá? Cada um na sua. Então imaginem o seguinte: como se na parte de dentro da testa de vocês tivesse uma tela de cinema onde vocês poderiam projetar esse filminho de vocês 
indo ao zoológico, chegando lá com essas pessoas que estão com vocês. Está aquele domingão gostoso, assim, está todo mundo animado. Aí vocês vão passando, conhecendo os animais. Vocês passam na jaula do tigre, olham pro tigre - nossa! Baita bichão bonitão! Aí vocês ficam um pouquinho lá, comentam: "Nossa, olha os pêlos do tigre, que legal esse tigre!" Então vamos para a próxima jaula. Lá tem um casal de leões enormes. "Mó" preguiçosão o leão, lá, comendo um pedação de carne. Aí vocês chegam num cercado que tem uns elefantes. Aí vocês vêem as girafas. Vocês vão vendo vários animais, vão passeando. Aí tem um daqueles viveiros com aves, com pássaros diferentes, uns pássaros maravilhosos, super bonitos; outros esquisitos. Vocês ficam lá olhando os pássaros. (Mais conversas, novamente peço silêncio.) Aí, de repente, vocês dão uma olhada numa jaula, assim, e falam: "Espera um pouquinho! Que bicho é esse?" É um bicho esquisito. Na verdade, vocês nem sabem dizer se é um bicho. Vocês sabem que é um ser vivo. Ele se mexe... Mas não dá nem pra saber o que é aquilo, porque ele é tão diferente! Está meio assim, de lado, vocês não conseguem ver direito... Vocês falam: "Gente, nunca vi esse bicho." Aí vocês chamam alguém, das pessoas que estão com vocês. "Vem dar uma olhada nesse bicho aquil" A pessoa fala: "Nossa! Nossa! Que que é isso?" Aí vocês começam a olhar bem. Vocês percebem que aquilo realmente não é um animal comum e, por tudo que vocês já leram, já ouviram as pessoas contarem e tudo, vocês concluem que aquilo só pode ser um monstro. $E$ aí vocês olham bem pra ele e vêem como ele é - se ele tem pêlos, se não tem... De que cor ele é? Tem olhos ou não tem olhos? Às vezes os monstros têm muitos olhos; às vezes não têm nenhum. Vê se ele tem orelhas. Como são as orelhas desse monstro? Se ele tem patas ou braços; coisas que se pareçam com pés, ou não. Vê como é que ele se mexe. Ele anda? Ele se arrasta? E ele faz algum barulho? Emite algum som? Faz um som parecido com o de um leão? Ou faz um som parecido com o de um pássaro? Olha bem pro monstro. E lá na sua imaginação, lá no zoológico, você vai comentando com a pessoa que está do seu lado: "Nossa, olha só que interessante, né? Dá uma olhada no jeitão desse monstro!" E aí vocês começam a observar o jeitão mesmo do monstro, como é que ele é: ele tem cara de ser mau? Ou ele tem cara de ser medroso que nem o monstro da música, meio tipo 
mariquinhas, assim? E aí vocês procuram perceber, procuram sacar qual é a desse monstro. Por que será que ele está preso lá? Só pras pessoas olharem? Será que ele é um monstro perigoso? Se ele estivesse solto no meio do zoológico ele estaria fazendo algum estrago? Ou as pessoas têm medo dele à toa; ele é super bonzinho e está lá preso de bobeira? Se ele for um desses monstros mais bravos, é lógico que vai ficar difícil chegar mais perto. Se vocês percebem que o monstro é meio tranqüilão e que ele chega meio perto da jaula, assim, experimenta falar com ele, talvez ele saiba falar. Aí, se ele souber falar, vocês fazem umas perguntas pra ele, sobre ele, assim, como é que ele foi parar lá, onde ele nasceu. Se ele não souber falar, vocês dão uma olhadinha, porque provavelmente ali do lado vai ter uma plaquinha, do lado da jaula do monstro, contando algumas coisas sobre ele: onde que ele nasceu, de que país ele veio, se é brasileiro mesmo ou veio de um outro país, mais ou menos quanto ele pesa, que tamanho tem, o que gosta de comer, qual é o prato predileto desse monstro, o que ele faz... vocês vão dando uma pesquisada, assim, sobre o monstro - pode ser conversando com ele, se ele souber falar, ou então consultando os dados sobre o monstro, lá na plaquinha do zoológico. Aí, quando vocês acharem que já olharam bem, que vocês já têm uma imagem bem clara do que é esse monstro, qual é o jeitão dele, qual é a personalidade dele, quais são as características dele... Bom, é claro que, como é um monstro muito diferente, um ser muito diferente dos outros bichos, você acabou ficando lá um tempão, né? Porque é muito diferente e cada um ficou muito curioso pra ver, pra aprender um pouco sobre esse monstro, conhecer... E aí, quando você estiver satisfeito de olhar o monstro, ou satisfeita, aí você dá um tchauzinho pra ele, se ele conversou com você, agradece: "Muito obrigado ou obrigada, seu monstro, pela entrevista concedida." Se ele é um desses monstros mais bravos ou incomunicáveis, você simplesmente mentalmente se despede dele e vai se afastando da jaula. E, é claro que depois de ficar tanto tempo assim olhando um monstro, você está até "meio assim", não consegue nem ver os outros bichos direito; você olha e fala assim: "Nossa, esses bichos são comuns, né? Eu acabei de ter uma experiência impressionante hoje, de um encontro com um monstro." Aí você vai indo embora do zoológico... E vocês vão abrindo os olhos, espreguiçando, vão se sentando. 
Agora, rapidinho, pra não perder as imagens que vocês acabaram de ter, vocês vão escrever."

Depois, cada criança sentou-se numa carteira e fiz a seguinte proposta:

"Não precisa se preocupar com letra bonita ou feia, o importante é que vocês não percam as imagens que acabaram de experimentar. Escrevam o mais rápido que conseguirem. Vocês vão contar como foi essa ida ao zoológico e aí vocês decidem se preferem contar desde o início - silêncio agora, concentração máxima! - desde que tiveram a idéia de ir ao zoológico, ou se já querem contar, chegando no zoológico, como é que foi. Evidentemente na hora que chegar o momento do encontro com o monstro, vocês vão dizer como ele é, "bababá", tudo o que vocês puderam observar desse monstro e tudo o que conseguiram descobrir sobre ele ou lendo a plaquinha ou conversando com ele."

Maiara perguntou se zoológico se escrevia com letra maiúscula, ao que respondi: "Não se preocupa com isso agora, o importante é que você escreva a sua experiência, depois você pode reler e corrigir."

As crianças escreveram e, conforme foram terminando, fui dando folhas de sulfite para que desenhassem. Depois fizemos um intervalo.

De volta do intervalo, fizemos uma votação para saber o que a maioria preferia: sentar no chão ou nas carteiras. A maioria preferiu as carteiras.

Distribuí as folhas com as redações trocadas e pedi que cada criança lesse um texto de um colega. A primeira criança reclamou da dificuldade para decifrar a letra. Depois dessa primeira leitura, a garota comentou que havia uns erros de pontuação e estavam faltando algumas letras. O que se seguiu foi que as crianças faziam questão de marcar os erros que encontravam no texto do outro. Lembrei-lhes que nesse momento de escrever, de colocar no papel as idéias que surgiram, eu havia dito que não se preocupassem muito com isso, mesmo. Mas comentei que em algum momento é preciso fazer uma revisão no texto, para dar uma melhorada nesses aspectos: "Na hora em que a gente está escrevendo e não está preocupada se está escrevendo com as letras certas, se está faltando letra ou não, o mais importante é escrever mesmo, colocar as idéias no papel. 
Depois, num outro momento, é que fazemos a revisão. E, para isso, é muito interessante que um colega leia o texto, porque muitas vezes a gente está tão envolvida com a produção, com a criação, que acaba fazendo até uns erros bobos mesmo e nem percebe. E quando a gente lê o nosso próprio texto, dificilmente percebe os erros, não sei se vocês já repararam. (Várias crianças disseram que sim.) Por hoje a gente vai ficar só na história, no conteúdo, tá?"

Cada criança leu uma história de um colega. Ao final da oficina, pedi que fizessem uma pesquisa sobre monstros para a próxima semana. ()

\section{OFICINA 5: MONSTROS E MITOLOGIA (19/06/97)}

As crianças que chegaram mais cedo começaram a desenhar na lousa antes de a oficina começar. Algumas desenharam monstros. Duas crianças me trouxeram a pesquisa sobre monstros que eu havia pedido na outra semana. Conforme os outros iam chegando, pedi que todos desenhassem monstros na lousa. Uma das crianças disse que não sabia desenhar, mas insisti que não se preocupasse demais e desenhasse alguma coisa; ele acabou topando e ficou muito satisfeito com seu desenho, divertindo-se com ele. Enquanto desenhavam, li uma definição de monstro trazida por uma menina do grupo.

Depois que todos já tinham desenhado algum monstro, chamei-os para sentar em roda, decidida a experimentar não começar com uma atividade corporal para ver se notava alguma diferença na disposição das crianças. Li mais um texto trazido por um garoto. Mostrei livros sobre monstros (alguns deles têm ilustrações tridimensionais que se movimentam conforme se abre e fecha o livro: estes despertaram particularmente 0 interesse de todos), dentre eles Monstros $\mathrm{e}$ mundos misteriosos: quase tudo o que você queria saber (PRIETO, Heloisa) do qual li "A misteriosa caixa de Pandora" (ANEXO 5). Aproveitei, para introduzir essa história, o fato de uma das crianças ter levado o livro Os doze trabalhos de Hércules, de Monteiro Lobato e contei-Ihes que se trata de uma versão do autor

\footnotetext{
${ }^{1}$ Esta oficina foi uma das mais produtivas. As crianças mostraram-se muito interessadas em todas as atividades propostas. Observe-se que reuni, aqui, atividades especialmente interessantes: música, imaginação criativa, escrita rápida, desenho... Para completar, propus uma discussão dos textos em grupo.
} 
de uma história que faz parte da mitologia grega. Depois de ler a história de Pandora, que narra como teriam surgido alguns monstros, falei sobre os mitos. As crianças pareciam um tanto dispersivas; propus então que ficássemos de pé e nos movimentássemos um pouco.

Fizemos movimentos de "twist", girando a bacia para um lado e outro. Depois, com os joelhos ligeiramente flexionados, calcanhares encostados um no outro e pontas dos pés separadas, transferimos o peso do corpo para a ponta de um dos pés, depois o mesmo com o outro pé; em seguida subimos nas pontas dos dois pés, com o peso do corpo centralizado, procurando encontrar um equilíbrio. Voltando a apoiar toda a planta dos pés no chão, chamei a atenção do grupo para a importância de mantermos o peso do corpo no meio dos pés, mostrando o que acontece com todo o corpo quando colocamos mais peso na parte da frente dos pés ou no calcanhar. Depois dessa atividade, fizemos um intervalo.

Depois, em roda, sentados no chão, folheamos o livro Monstros (HAWKINS, Colin e Jacqui) e lemos alguns trechos.

Cada um sentou-se numa carteira e inventou um "cardápio de monstro", como os que tínhamos visto no livro, com comidas esquisitas e nojentas. Todos demonstraram muito envolvimento com a atividade. Depois trocaram de folha com o colega ao lado e um leu o texto do outro. Como surgissem reclamações quanto ao teor pouco aperiente das produções ("Ai, que sacanagem, agora vai ser difícil almoçar!"), resolvi propor que escrevessem um segundo cardápio, mas dessa vez imaginando que era para um monstro "criado por um gourmet francês, super fresco, que adorava pratos maravilhosos. Só podia ter comidas muito gostosas no cardápio." Dei cinco minutos para escreverem (como no exercício anterior) e depois fizeram novamente a troca. (C)

\footnotetext{
${ }^{1}$ Houve muito envolvimento por parte das crianças na confecção dos cardápios. Na hora de ler os textos, todos divertimo-nos muito.
} 


\section{OFICINA 6: PERSONAGENS DA MITOLOGIA GREGA (26/06/97)}

Propus que cada criança inventasse uma sequência rítmica com palmas, que todos deviam imitar. Começamos com três palmas, depois passamos para quatro. Em seguida, em vez de bater palmas, batemos com os pés no chão. Todos se envolveram muito com a atividade.

Depois, conversamos em roda sobre mitologia em geral e mitologia grega, aprofundando a discussão que se iniciara na outra semana. As crianças falaram bastante sobre o que sabiam a respeito, contaram histórias que já tinham ouvido ou lido sobre personagens e histórias da mitologia grega. Contaram que tinham lido na escola a história de Sócrates; esclareci que se trata de um personagem da história da Grécia, ou seja, um homem cuja existência não é uma questão de crença, como no caso dos deuses e outros personagens mitológicos: "Há casos em que um ser humano que existiu de verdade inspira a criação de uma lenda; então parte da história que se conta a seu respeito de fato aconteceu e parte é fruto da imaginação de um povo. Um caso famoso desse tipo é a história de Ulisses, personagem da história da Grécia que na obra Odisséia, narrada por Homero (aliás não há certeza sobre o fato de ter realmente existido um homem chamado Homero) que vive aventuras fantásticas, enfrentando monstros e outros seres sobrenaturais na viagem que faz de Tróia a Ítaca, de volta para casa após uma longa guerra da qual participara."

Comentou-se sobre o desenho "Hércules", que entraria em cartaz naquela semana. (Surgiu a idéia de irmos todos ao cinema, mas acabou não dando certo.) Fizemos então um intervalo.

Depois, olhamos ilustrações do livro A Grécia: mitos e lendas (QUENSEL, Alain; TORTON, Jean) e li o texto sobre os doze principais deuses gregos: "Em visita ao Olimpo" (ANEXO 6). Continuamos conversando sobre mitologia grega até o final da oficina. ( ${ }^{1}$

\footnotetext{
${ }^{1}$ Mais uma vez: atividade muito longa acaba ficando enfadonha... Pois essa "conversa" acabou virando uma "aulinha" sobre mitologia, que poderia ter sido muito mais interessante se eu tivesse selecionado, por exemplo, uma passagem da Odisséia e contado para eles.
} 
OFICINA 7: "MÃO NA MASSA" (03/07/97)

Para esta oficina havia sido planejada a modelagem de personagens em argila. Não tendo encontrado o material em lojas do ramo, decidi ensinar as crianças a preparar massa de farinha com sal e água. Antes disso, ouviriam o mito grego segundo o qual Prometeu teria criado os seres humanos a partir de bonecos modelados em argila e depois os teria soprado, dando-lhes vida. A idéia era que as crianças "brincassem de Prometeu" e soprassem seus personagens. Em seguida produziriam um texto em escrita rápida.

No entanto, alguns problemas aconteceram: o operador de vídeo faltou sem avisar e o ficamos esperando um pouco. Perdi mais alguns minutos para tentar improvisar uma forma de fixar a câmera, de modo que restou bem menos tempo do que se havia calculado. A oficina consistiu então, basicamente, na narração da versão acima mencionada do mito da criação dos seres humanos por Prometeu e na preparação da massa de farinha, o que também levou bem mais tempo do que eu havia previsto. No entanto, embora tudo tenha saído diferente do que fora programado, as crianças adoraram brincar com a massa. $\left(\AA^{\circledR}{ }^{1}\right.$

OFICINA 8: CONTOS POPULARES (29/10/97)

Iniciamos batendo com os pés no chão, depois diminuímos a velocidade e observamos onde recaía o apoio do peso do corpo. Observamos que a maioria tinha tendência a pisar mais no calcanhar. Retomei a recomendação já dada em outra oficina de que o peso do corpo deveria se concentrar no meio dos pés e mais na borda externa do que na interna. Em seguida fizemos movimentos

\footnotetext{
${ }^{1}$ Mais tarde pude notar como esta oficina, em que "apenas" brincamos, ficou marcada na memória das crianças como uma das "mais legais". Em O brincar e a realidade (p. 74-75) Winnicott diz: "É bom recordar que o brincar é por si mesmo uma terapia. Conseguir que as crianças possam brincar é em si mesmo uma psicoterapia que possui aplicação imediata e universal, e inclui o estabelecimento de uma atitude social positiva com respeito ao brincar. (...) A característica essencial do que desejo comunicar refere-se ao brincar como uma experiência, sempre uma experiência criativa, uma experiência na continuidade espaço-tempo, uma forma básica de viver."
} 
giratórios com as pontas dos pés no chão. Orientei-os a fazer com que o movimento partisse da articulação coxo-femural e a pensar no fêmur em rotação externa, procurando fazer um sutil movimento nesse sentido, agora com os pés paralelos e "fixos" no chão e sem deixar os joelhos esticados demais.

Uma vez sentados, eu disse o seguinte (resumidamente): "No semestre passado, trabalhamos bastante com personagens. Agora nós vamos colocá-los em histórias. Para isso, vamos estudar um determinado tipo de história, para conhecer o seu "segredo", ou seja, sua fórmula. As histórias que vamos estudar são contos populares: histórias que foram sendo transmitidas de geração para geração oralmente, quer dizer, essas histórias eram contadas. Algumas pessoas, como por exemplo os irmãos Grimm, resolveram registrar as narrativas que ouviam dos contadores de histórias e assim nasceram os livros de contos populares. Os contos de fadas são contos populares. Populares porque vêm do povo, é o povo que vai contando, passando de boca em boca e ninguém sabe quem inventou, quem criou. Vamos estudar, então, uma fórmula de contos populares. Ou seja, vamos ver o que não varia, os elementos que aparecem em todas as histórias de um determinado tipo. E por que é útil conhecer essa fórmula? Porque ela é como uma massa básica de bolo. Conhecendo a receita da massa básica podemos, a partir dela, inventar outras receitas mais sofisticadas. Então nós vamos observar o seguinte: em todos os contos existe uma situação inicial na qual são apresentados os personagens e o que está se passando. Depois ficamos sabendo qual é o problema, o conflito - geralmente o personagem principal da história tem um problema a resolver. Assim, alguns acontecimentos preparam a solução do problema ou conflito que, no caso dos contos populares que vamos estudar, é sempre um final feliz."

Esta "aulinha" foi dada, evidentemente oferecendo espaço às crianças, em primeiro lugar, para dizer o que já sabiam a respeito; em segundo, para ir fazendo perguntas, esclarecendo dúvidas etc. (C) Fizemos então um intervalo.

Voltei a chamar a atenção para o fato de haver esses estados básicos nos

\footnotetext{
${ }^{1}$ Considero que o espaço oferecido às crianças para a construção de um conhecimento a respeito da estrutura da narrativa dos contos foi muito reduzido - de forma diversa do que acontecera em relação ao elemento personagem. Creio que a limitação de tempo funcionou como um "empurrão" para que eu caísse no velho equívoco de oferecer aos alunos um "pacote fechado" de conceitos. (Voltarei a este ponto nos próximos comentários e também no capítulo "Discussão e Considerações finais".)
} 
contos: partindo de uma situação inicial, passa-se por um conflito (tensão) sendo que muitas vezes no início do conto o equilíbrio já é rompido. Depois, o conflito é solucionado: final feliz, alegria, restauração do equilíbrio. Pedi então que representassem esses diferentes estados, conferindo a cada um deles uma expressão corporal - um gesto, uma pose. Algumas crianças acharam a proposta divertida; outras relutaram em participar, sentindo-se tímidas.

Ao final, pedi que trouxessem para a próxima semana algum material sobre contos populares. (C)

\section{OFICINA 9: CONTOS POPULARES E LITERATURA INFANTIL (05/11/97)}

Retomei o exercício de concentrar o apoio no centro dos pés e observar a rotação externa dos fêmures, mantendo os joelhos ligeiramente flexionados. Depois fizemos movimentos elípticos com as mãos à frente do corpo, observando a posição dos cotovelos (abertos), sem levar o ombro para perto do pescoço e sim mantendo uma distância entre eles, uma largura.

Duas crianças trouxeram contos, todos dos irmãos Grimm. As outras esqueceram de trazer material. Eu havia levado o livro Os contos de Grimm

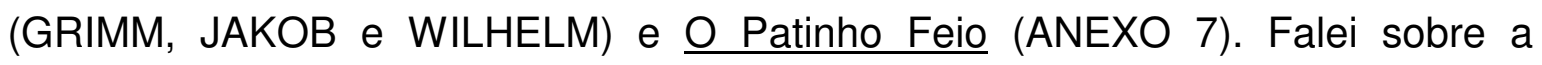
diferença entre este conto e os presentes na compilação dos Grimm (conforme se esclareceu no capítulo IV desta dissertação).

"Nós vamos observar que aqueles estados dos quais falamos na oficina anterior (equilíbrio, conflito e resolução ou desenlace) estão presentes também nesta história."

As crianças manifestaram o desejo de ler o livro e combinamos que cada uma leria uma parte. No entanto, não deu muito certo: a leitura acabou ficando muito longa e cansativa. Terminado o tempo, interrompi a leitura e disse que

\footnotetext{
${ }^{1}$ Teria sido interessante pedir que colecionassem imagens que para eles representassem esses estados: recortes de revistas, livros, fotos, cenas de filmes e da vida cotidiana, outdoors, desenhos, etc, etc, etc... O mesmo quanto ao pedido de "material sobre contos", que poderia ter sido o mais aberto possível: objetos quaisquer que, por algum motivo, lhes lembrassem os contos. Estaríamos trabalhando com ícones, metáforas, de uma forma mais divertida e mais significativa.
} 
contaria o final da história na próxima oficina. @ ${ }^{1}$

OFICINA 10: RITMO E PULSAÇÃO (12/11/97) $\AA^{2}$

Observação: Graziela faltou

Retomei O Patinho Feio (ANEXO 7), contando a parte que faltava da história. Pontuei novamente o fato de haver nela os elementos básicos dos contos populares.

A seguir, conversamos sobre os estados emocionais e sua relação com ritmos e velocidade. "Nos filmes, a trilha sonora sempre tem a ver com o que está acontecendo. A música tem esse poder de induzir ou reforçar um estado emocional. Tanto que todo mundo conhece o velho truque de cortar o som da TV quando a tensão está insuportável. Em determinado tipo de história, a tensão é explorada ao máximo através do suspense, que adia a solução do conflito e vai deixando a gente com o coração acelerado."

Fizemos um exercício parecido com o de uma outra oficina, em que inventamos ritmos batendo palmas. Chamei a atenção das crianças ao fato de que um mesmo ritmo pode ser executado de forma lenta ou rápida.

(Eu havia programado passar trechos de dois filmes: um mostrava o momento em que se apresenta o conflito; o outro era um final feliz. A intenção era observar os elementos que revelam tensão e relaxamento associados ao conflito e sua solução, prestando especial atenção à trilha sonora. Contava com um aparelho de vídeo que costumava ficar na sala e que tinha sido disponibilizado para nosso uso, se dele tivéssemos necessidade. No entanto, exatamente neste dia, o aparelho havia sido retirado da sala...)

\footnotetext{
${ }^{1}$ Acredito que poderia ter sido mais produtivo se eu tivesse interrompido essa leitura antes, terminando de contar a história de uma forma que cativasse a atenção das crianças. Sobraria tempo, então, para que eu contasse também uma história dos Grimm para observarmos, depois, a presença dos "estados" estudados nos dois contos. Demorei para me dar conta de que, nesse caso, "ouvir a demanda" dos alunos resultara em uma atividade enfadonha e pouco produtiva. Como professora, era meu o papel de avaliar esse resultado e mudar o rumo da atividade.

${ }^{2}$ Ver itens Os contos pulsam: a fórmula simplificada, no apêndice.
} 
Voltamos a falar sobre a estrutura básica do conto, entrando em detalhes sobre o que há em cada um dos três momentos principais:

- Situação inicial: os personagens principais são apresentados e é narrado o que está se passando com eles. Há sempre um protagonista, muitas vezes há também um antagonista. Os outros são personagens coadjuvantes. (Expliquei o que são estes tipos de personagens.)

- Conflito e acontecimentos em torno dele: o problema central do conto, que deverá ser resolvido no final. Por exemplo, em O Patinho Feio (ANEXO 7), o problema é o fato de ele ser diferente e por isso rejeitado por todos. Muitos acontecimentos giram em torno deste fato: ele foge e é rejeitado em diversas situações diferentes.

- Desenlace: é o final feliz, a resolução do conflito. No final, algo acontece e desfaz o nó da trama, resolvendo-se o problema. Este algo, no entanto, em geral não acontece de repente, "do nada", mas vai sendo preparado ao longo do conto, no decorrer dos acontecimentos em torno do conflito. Portanto, algo se transforma do começo para o final do conto e esses acontecimentos vão preparando essa mudança.

Fizemos então um intervalo.

A seguir, propus que escrevessem um esquema de um conto. Frisei que 0 conto propriamente dito seria escrito num outro momento; agora deveríamos nos preocupar somente em fazer um esboço, um esquema, contar quem seriam os personagens principais, qual seria o problema que enfrentariam e como este problema seria resolvido. No entanto, a maioria já começou a escrever a história em si. Tentei explicar melhor, pedindo que não apagassem o que já estivesse escrito, mas algumas crianças apagaram assim mesmo. Neste momento ocorreume que seria interessante pedir que escrevessem com caneta, para evitar a "tentação" de apagar mesmo quando se tenha pedido para que não o façam, seja com o objetivo de preservar os "rascunhos", quando é interessante considerá-los posteriormente, seja quando não se quer perder tempo com correções para não interromper o fluxo criativo.

A maioria conseguiu indicar os principais elementos da história, sendo que 
alguns textos resultaram numa mistura de formas: esquema e narrativa.

\section{OFICINA 11: RITMO, PULSAÇÃO E ÁRVORE DA CRIAÇÃO (19/11/97)}

Observações: Pedro faltou.

Houve problema em relação à utilização da sala, pois a escola precisava dela naquele dia e tinham se esquecido da oficina. Tivemos de mudar para outra sala e isso atrasou o andamento das atividades.

Uma vez iniciada a oficina, novamente batemos palmas, sentados a uma mesa, na qual também batucamos diferentes ritmos. Conversamos sobre pulsação, lembrando que o coração pulsa em diferentes velocidades conforme a situação pela qual estamos passando e a emoção que vivemos: "Quando estamos ansiosos, nervosos por causa de uma prova ou de um encontro com o ser amado, o coração pulsa rápido. Se estamos tranqüilos ou entediados, a velocidade é lenta. Se temos um problema, ficamos tensos até que consigamos resolvê-lo - então voltamos a relaxar."

Trabalhamos com a idéia de ritmo ligado à pulsação e com a noção de transformação, tudo isso relacionado aos processos observados nos contos, conforme já foi exposto.

Distribuí, então, canetinhas coloridas e fizemos uma "chuva de palavras". Dentre as palavras faladas, o grupo escolheu "amor". Distribuí folhas de sulfite e fui ensinando como construir uma árvore da criação: fomos todos colocando (tanto no centro como nos galhos e ramos) palavras ditas pelas crianças no esquema de "chuva de palavras". Como a sala não dispunha de lousa, fiz uma árvore numa folha de papel sulfite e fui mostrando às crianças.

Depois distribuí mais folhas em branco para que fizessem uma segunda árvore que deveria ter, no centro, a palavra "conto" ou "história" ou alguma outra relacionada ao tema. Em seguida, dei mais folhas em branco, nas quais deveriam fazer uma árvore com idéias que surgissem ao ouvir uma determinada música. A 
primeira que coloquei pertence à trilha sonora do filme ET, o extraterrestre e indica um clima de suspense. A seguir, a atividade foi repetida, mas dessa vez com a música Happy Ending da trilha sonora do filme "A Pequena Sereia". Depois li as árvores de cada um para o grupo. As crianças identificaram as trilhas e muitas das palavras anotadas referiam-se aos filmes.

Encerradas as atividades da oficina, sorteamos o amigo secreto, que seria revelado no último encontro. (C) 1

\section{OFICINA 12: ÁRVORE DE UM CONTO DOS IRMÃOS GRIMM (26/11/97)}

Fizemos exercícios de respiração e pedi que observassem o contraste entre o pulmão vazio e cheio, que são estados diferentes e podem também representar um movimento de pulsação.

"E o que isso tem a ver com os contos? Bem, nos contos populares que vamos estudar, que sempre têm final feliz, coloca-se um problema que é resolvido: o problema é um momento de tensão e o desenlace um momento de relaxamento ou repouso ou restauração do equilíbrio. Por isso, podemos dizer que os contos respiram. Podemos dizer também que esses contos pulsam."

Depois, contei para a turma a história "O rei barba-de-melro" (ANEXO 8). Todos acompanharam com muito interesse. Terminada a história, fui para a lousa e fiz, junto com crianças, uma árvore do conto. Discutiu-se o que deveria ir no centro e decidiu-se por "arrogância castigada". Depois, cada criança foi falando uma palavra e dizendo se deveria ser colocada como galho ou ramo de algum outro galho.

Pontuei a presença, neste conto, dos elementos estudados: situação inicial com apresentação do conflito, acontecimentos em torno do conflito (processo que

\footnotetext{
${ }^{1}$ Houve muita participação e interesse nessa atividade. Ao final, antes de sortearmos o amigo secreto, conversamos sobre até quando iriam as oficinas. Disse que poderíamos ter mais duas ou três, conforme a disponibilidade do grupo. Decidiu-se por fazer mais três. Perguntaram se continuaríamos no semestre seguinte e eu disse que talvez parássemos; algumas crianças "protestaram", uma delas chegando a sugerir que trabalhássemos nas férias.
} 
engendra uma transformação), finalmente o desenlace. (C) $\AA^{1}$ Fizemos então um intervalo, após o qual entreguei às crianças o texto produzido havia duas semanas (esquema de um conto, com indicação dos personagens, conflito etc). Li para o grupo o texto de cada um e pontuei quais elementos estavam faltando para que pudessem escrever a história. Numa das leituras, algumas crianças fizeram comentários jocosos em relação ao texto do colega. Disse então que não valia ser arrogante como a princesa do conto e ficar apontando o dedo e rindo dos outros.

Pedi que fizessem uma árvore de sua história e a escrevessem completa em casa para a próxima semana.

\section{OFICINA13: CRÍTICAS E SUGESTÕES EM GRUPO (03/12/97)}

Fizemos, novamente, exercícios de respiração como na semana anterior. Insisti na metáfora: os contos respiram, pulsam.

Retomamos então os textos produzidos por eles. Li cada um em voz alta e foram feitos novos comentários, a partir dos quais pedi que fizessem uma revisão cuidadosa do texto em casa. Lembrei-me então de sugerir que escrevessem pulando linhas sempre, pois isso facilita a revisão quando queremos acrescentar trechos, fazer correções ou sinais e observações no meio do texto, como asteriscos, por exemplo. A atividade de discussão dos textos tomou todo o tempo da oficina.

\footnotetext{
${ }^{1}$ Esta atividade foi especialmente interessante e envolvente para as crianças. Creio que neste momento - em que não me limitei a dar uma "aulinha", como havia feito na oficina 8 , mas contei uma história e propus uma atividade de que as crianças foram convidadas a participar ativamente - houve um "entendimento" muito maior sobre os contos. Penso que teria sido mais interessante se eu nem mesmo tivesse dado a tal "aulinha", mas sim proposto várias atividades como essa, a partir das quais as próprias crianças fossem tendo elementos para chegar por si mesmas às noções que eu pretendia ensinar. A estrutura dos contos populares de magia emergiria então de experiências significativas, vivenciadas pelas crianças em vez de ouvir um "blá-blá-blá" de difícil digestão. Vale lembrar aqui as palavras de Piaget: "Mas não foi senão com a pedagogia experimental deste século que se compreendeu verdadeiramente o alcance do problema. Percebeu-se que o verbalismo, que constitui o grande obstáculo à compreensão da criança, não é devido somente às insuficiências do ensino oral, mas ao seu próprio princípio, quando este ensino é concebido como o principal instrumento educativo. A criança não é um ser passivo, do qual se trate de rechear o cérebro, mas um ser ativo, cuja tendência à pesquisa espontânea tem necessidade de alimentos. Essa mudança radical de perspectiva, operada pela "escola ativa", não suprime de modo nenhum a lição, mas a reduz a uma função mais modesta de resposta às questões que o aluno propõe a si próprio e a subordina, assim, ao trabalho individual."(PIAGET, Jean. O trabalho em equipes na escola. p. 3)
} 


\section{OFICINA 14: METÁFORA E TRANSFORMAÇÕES (10/12/97)}

Obs.: Pedro faltou.

Aproveitei revelação do amigo secreto para fazer uma brincadeira de adivinhar quem tinha tirado quem, na qual estava presente o conceito de metáfora. Antes de dizer o nome do colega sorteado, cada um tinha de dizer: ele ou ela sendo uma fruta, que fruta seria? Assim também para planta, música e animal. Trocamos os presentes. A seguir, fizemos um intervalo.

Distribuí uma folha que havia preparado com um pequeno texto explicando o que é metáfora, exemplos e frases a serem completadas. (ANEXO 9)

Algumas crianças tiveram dúvidas; dei mais explicações sobre o conceito de metáfora e exemplos, aproveitando a brincadeira de revelação do amigo secreto. Dei também um texto digitado sobre os principais conceitos que estudamos nas oficinas e uma árvore do trabalho realizado ao longo do ano.

Ofereci-Ihes então sucata, papel crepom, tesoura, cola, grampeador e fita adesiva. Propus que confeccionassem um objeto que representasse um personagem da história que haviam produzido, procurando evitar fazer bonecos: 0 importante era que o objeto transmitisse uma idéia, funcionando como um ícone. Assim como na brincadeira da revelação do amigo secreto: não era que a pessoa se parecesse necessariamente com uma pêra, por exemplo, mas havia algo nela que lembrava a fruta; havia algo em comum, como por exemplo a delicadeza, suavidade etc. As crianças confeccionaram os objetos com grande interesse.

Antes de nos despedirmos, dei a cada um uma pasta contendo folhas de sulfite em branco, um estojo de canetinhas coloridas, um caderno de brochura, uma caneta esferográfica e massinha de modelar colorida. Disse que era um presente que thes oferecia como sinal de minha gratidão por terem participado das oficinas e que esperava que o material servisse como estímulo para que 
inventassem e escrevessem muitas histórias.

\section{OFICINA 15: REVISÃO E SORTEIO DE PERSONAGENS (18/03/98)}

Obs.: Neste ano, dois alunos mudaram para o período da manhã. O tempo disponível para o trabalho passou, por isso, a ser menor: uma hora.

Recordamos alguns aspectos já mencionados em outras oficinas: apoio do corpo no meio dos pés, cuidado para não esticar demais os joelhos para trás e não levantar os ombros etc. Fizemos alguns exercícios como girar os pés esfregando-os no chão e um balancinho, procurando alargar os ombros.

Depois, todos sentados à volta de uma grande mesa, retomamos os aspectos mais importantes que havíamos estudado dos contos populares e principalmente dos contos de fadas.

Cada criança sorteou, então, três personagens, dentre alguns que eu havia inventado previamente. Levaram para casa a "ficha do conto" (ANEXO 10) e os personagens sorteados; pedi que pensassem como seria seu conto e completassem a ficha, mas sem escrever, por enquanto, pois esse trabalho seria feito na próxima oficina.

\section{OFICINA 16: ESCRITA DE UM CONTO DE FADAS (25/03/98)}

Começamos batendo com os pés no chão, mexendo os braços. Ombros para baixo, largos.

Depois as crianças sentaram-se a mesas individuais.

Distribuí o "roteiro do conto" (ANEXO 11) @ ${ }^{1}$ e li em voz alta o texto inicial.

\footnotetext{
${ }^{1}$ Continuando na linha dos comentários feitos sobre as oficinas 8 e 12: atividades como estas que propus, utilizando "ficha/roteiro do conto", correm um sério risco de tornar-se muito fechadas. Ainda bem que tive o bom senso de não ficar rígida demais na proposta...
} 
Dei espaço para fazerem perguntas.

Fiz uma leitura do roteiro do conto de fadas em três etapas, dando um tempo para que escrevessem cada parte. Procurei controlar o tempo: 5 min para o começo, 7 min para o meio e 5 min para o fim.

Algumas crianças não conseguiram terminar de escrever o conto. Ficamos de concluir a atividade na semana seguinte e combinamos uma festa de encerramento depois da última oficina.

\section{OFICINA 17: QUESTIONÁRIO (01/04/98)}

Dançamos um pouco ao som de um CD que uma das meninas tinha levado. Disse para não se esquecerem de observar: se estavam com o peso do corpo no meio dos pés, joelhos nem muito esticados, nem dobrados, quadril não arrebitado e também não pra frente, ombros pra baixo e abertos, peito largo sem estar estufado, pescoço alongado.

A seguir, as crianças responderam a um questionário de avaliação pessoal das oficinas (ANEXO 12).

Conversamos sobre a necessidade de fazer mais uma oficina para terminar de escrever a história que havíamos começado; na semana seguinte conversaríamos sobre a festa de encerramento. Disse que, para quem quisesse continuar, propunha-me a seguir com as oficinas. Comentei ter percebido que os últimos encontros tinham sido meio chatos, provavelmente devido ao fato de eu estar ansiosa para terminar e dar conta de fazermos as atividades dentro do tempo, que agora é mais curto. Disse que esse clima tenso não tinha nada a ver com a proposta e certamente prejudicava o trabalho, fazendo com que este perdesse a graça. As crianças concordaram e propusemo-nos então a procurar voltar àquele clima anterior, muito mais divertido e produtivo. 


\section{OFICINA 18: QUESTIONÁRIO E CONTINUAÇÃO DO CONTO (08/04/98)}

Obs.: Pedro e Talita faltaram.

Apenas pedi que observassem a postura e imaginassem quais partes do corpo são usadas no ato de escrever. Chegou-se à conclusão de que praticamente o corpo todo acaba sendo solicitado de alguma forma.

Expliquei que algumas perguntas do questionário tinham deixado muita margem a dúvidas. Pedi que respondessem às questões reformuladas.

Com base no conteúdo de um texto específico, considerei importante fazer algumas ponderações sobre a diferença entre censurar e observar uma inadequação a uma proposta: "Não se trata de censurar o que foi escrito, mas sim de procurar chamar a atenção de vocês para que se mantenham dentro da proposta, qual seja, escrever um conto seguindo o modelo de conto popular de fadas." Peguei o texto da Maiara como exemplo para lembrar-lhes que nos contos de fadas o protagonista sempre é do bem e quem é do mal é punido.

Fiz então um comentário sobre o meu pedido para que pulassem linhas: "É preciso ter humildade diante do texto, pois nunca sabemos de antemão se vamos querer mudá-lo depois." Falei sobre a metáfora do diamante: uma preciosidade que pode ser melhor apreciada se for lapidada. "Quando a gente tem uma idéia e coloca no papel, a primeira versão do texto é uma pedra bruta. Por isso é que a gente fazia aquele exercício de escrever bem rápido, sem pensar muito: para extrair de dentro nós mesmos essa pedra bruta. Depois vem o trabalho de edição, de lapidação: a preciosidade do texto vai se revelando conforme vamos mexendo nele, tirando uma coisinha ali, acrescentando outra aqui... Mexam no texto o quanto quiserem, puxem flechinhas, façam a sua lapidação. É importante que fique legível; mas de qualquer forma, o que eu não entender, pergunto." 
As crianças deram continuidade ao conto, mas havia então muito pouco tempo e ninguém terminou. Combinamos que continuaríamos na próxima oficina.

\section{OFICINA 19: CONTINUAÇÃO DO CONTO (15/04/98)}

Dançamos um pouco em roda, observando todos aqueles aspectos posturais de sempre.

Levantei a idéia de montar um livro com os contos do grupo e todos se animaram muito.

Expliquei que havia feito comentários por escrito no texto de cada um: "Vocês vão ler o que eu escrevi aí e se concentrar. Hoje vocês vão entrevistar os personagens para colher algumas informações que estão faltando nos contos. Nós vamos fazer um daqueles exercícios de imaginação, como no dia em que visitamos um zoológico onde tinha um monstro, lembram? Então, enquanto vocês lêem, já vão convocando o personagem para a entrevista; enviem uma mensagem pra dentro de vocês mesmos marcando a entrevista com o personagem."

Fizemos então um "ensaio" das palavras mágicas "sim-salabim-bim-bim" (enquanto pronunciávamos as palavras, eu tocava símbalos) que abririam o PORTAL DO MUNDO ENCANTADO DOS CONTOS DE FADAS. "De olhos fechados, imagine o portal à sua frente. $O$ personagem estará esperando por você do outro lado." Todos falaram as palavras mágicas juntos. "Imagine o portal se abrindo. Lá está o personagem. Ele vai conduzir você para o lugar onde a entrevista vai acontecer. Você chega a este local, senta-se confortavelmente e faz as perguntas que quiser. Preste bastante atenção ao que ele responde."

Disse para não mencionarem a idade dos personagens, pois eu colocara a idade de cada um nas "fichinhas" sorteadas, mas fora bobagem ter feito isso, já que se trata de uma informação absolutamente desnecessária, em se tratando de contos de fadas, nos quais nunca se diz a idade precisa dos personagens. 
OFICINA 20: ENCADEAMENTO (29/04/98)

Obs.: Gabriela faltou.

Formamos uma roda, todos em pé, cada um entrelaçando os braços nos de quem estava ao lado. Perguntei então o que estávamos parecendo e chegouse à palavra "corrente". "E como se chama cada pedacinho de uma corrente?" Falaram "argola"; depois "elo". Perguntei o que acontece quando um dos elos se movimenta. Joguei então o corpo para frente e os que estavam ao meu lado se desequilibraram. Comentou-se que, quando um elo se move, os outros principalmente os mais próximos - também se movem, uma vez que estão ligados um ao outro, conectados, entrelaçados.

A seguir, as crianças sentaram-se em carteiras individuais e distribuí uma folha que tinha preparado (ANEXO 13), com verbetes extraídos do dicionário referentes a "cadeia", "encadeamento", "encadear". Propus que grifassem os verbetes que tivessem relação com "conexão", "ligação", "sucessão". Em aproximadamente quinze minutos, todos terminaram; então passamos a uma discussão sobre cada um dos verbetes. Fui lendo um a um e perguntando o que cada criança tinha grifado.

Comentei então sobre a pressa que eles pareciam ter de "se livrar" do texto logo depois da criação. Comparei então à situação de ter um filho: após a concepção - momento de pura fruição, de gozo (a maioria das crianças mostrou um certo constrangimento frente ao fato de eu estar falando explicitamente de sexo) - há a gravidez, em que muitas vezes se sente enjôo, mal-estar... E, depois do parto, é preciso cuidar do bebê; há momentos maravilhosos e outros difíceis.

Distribuí então os textos digitados, com espaços entre as linhas para que pudessem acrescentar coisas, usar asteriscos, flechinhas etc e terminassem a história. A maioria mostrou-se indisposta a mexer no texto, disseram não gostar 
mais de "seus filhos", queriam levar os textos para terminar em casa. Alguém perguntava alguma coisa e eu ia atender; enquanto isso os outros faziam um tumulto, conversavam entre si, reclamavam e insistiam muito para que os deixasse levar os textos para casa. Pedi que se concentrassem para terminar a história e disse que, na próxima etapa, após o término desse texto, para quem fosse continuar, haveria chance de levar textos para casa; este, no entanto, eu queria ter inteiro, pois fazia parte de minha pesquisa e eu não queria correr o risco de perder partes, como havia acontecido com alguns dos textos feitos no final do ano anterior. Disse que não podia obrigá-los a terminar, mas que gostaria muito que todos fizessem um compromisso comigo de terminar este texto; depois, quem quisesse continuava; quem não quisesse parava. A partir de então, fez-se um silêncio relativo; cada um foi escrevendo e me chamando para tirar dúvidas, dar opiniões etc.

\section{OFICINA 21: LEITURA E REVISÃO EM GRUPO (06/05/98)}

Cada um de pé em frente a uma carteira, fui conduzindo um breve "aquecimento" corporal, pedindo sucessivamente que prestassem atenção nos pés, joelhos, bacia, costelas, ombros, pescoço... Batemos um pouco os pés no chão; pedi que procurassem "chegar", concentrar-se, notando como o bater dos pés tinha uma repercussão no corpo todo, até o pescoço e a cabeça.

A seguir, sentaram-se e deram continuidade à produção do texto. Quem já tinha terminado ficou revisando. Disse-Ihes: "Lembram daquilo que eu falei sobre a humildade diante do texto? Pular linhas... Porque a gente sempre vai mexer no texto, ele sempre vai ficar melhor do que era no primeiro jorro. Vamos dar continuidade ao que estávamos fazendo; nesse texto que eu já digitei, sinalizem para mim todos os asteriscos - se vocês acharem que está dando margem a dúvidas, numerem... Então, agora, vamos concentrar, cada um fica na sua. Depois, se der tempo, a gente vai fazer uma roda pra ler as histórias, porque só eu conheço as histórias de todo mundo e eu gostaria que todo mundo 
conhecesse, porque as histórias estão muito legais. Não se preocupem em passar a limpo, eu é que vou fazer isso - marquem o texto pra mim. Grázi, você que já terminou, aproveita esse tempo agora pra reler com amor e carinho, seu texto está bonito - gente, sinceramente, os textos de vocês estão muito legais. Então, aproveita, mexe no texto, melhora o que der para melhorar. Então, não se esqueçam de marcar de um jeito que fique claro, senão depois eu não vou entender, pra poder passar a limpo. (...) O texto de vocês merece esse cuidado. (...) Depois a gente vai ter um momento mais legal, de troca; agora é um momento legal, também, mas exige concentração."

Às vezes eu chamava a atenção de todos e fazia uma observação, por exemplo, em relação ao fato de ser necessário colocar todos os verbos no passado. Comentei que Pedro era o único que não tinha se esquecido disso nenhuma vez e Celso somente em uma ou duas frases. Muitas vezes, alguém dizia que não tinha boas idéias; num dado momento, eu disse: "Não quero mais ouvir ninguém dizer que não tem boas idéias, que não tem imaginação, porque isso é mentira!" Grázi disse: "Eu não tenho idéias!"; Maiara emendou: "Eu tenho idéias!" Brinquei: "Repitam comigo: eu tenho lindas idéias! " Alguns introduziram um não na frase...

Fui atendendo às crianças à medida que me solicitavam e assim transcorreu todo o tempo da oficina, sem que sobrasse tempo para lermos os textos em roda. (C) ${ }^{1}$ Combinamos então que continuaríamos da mesma forma,

\footnotetext{
${ }^{1}$ A situação era um tanto extenuante: sempre havia mais de uma criança me solicitando ao mesmo tempo e quem ficava me aguardando parava de mexer no texto - claro que acabava conversando com os colegas, ou levantando da carteira; os outros se dispersavam... Ficou evidente uma indisposição muito grande de todos para concentrar-se, cada um em seu próprio texto. Aqui cabem dois comentários: em primeiro lugar, tratavase de uma situação imposta, já que as crianças tinham manifestado insistentemente o desejo de fazer o texto na paz do lar. Esse desejo, no entanto, chocava-se com a minha necessidade de ter certeza de que nenhum material se perderia, como já acontecera antes. O segundo ponto refere-se a outro desejo das crianças que se chocava com uma "necessidade" minha: elas, de várias formas e em vários momentos, mostraram-me que não se sentiam muito entusiasmadas a seguir revisando o mesmo texto; eu achava que isso era fundamental, baseada num princípio válido, mas muito apegada a uma forma, a um método (talvez resignada diante da crença de que "fazer revisão é chato, mesmo...”). Ou seja: achava que era fundamental passar para eles a idéia de que é muito importante revisar um texto, que um texto recém escrito deve ser encarado como uma primeira versão de algo que pode melhorar muito etc; ainda acredito nisso, mas talvez haja uma forma de flexibilizar um pouco essa atividade, quando se trata de crianças produzindo textos. Parece-me, observando o que ocorreu nesta oficina e nas seguintes, que a revisão feita dessa forma é cansativa para elas, penosa... Penso que o trabalho só foi até o fim graças ao vínculo que tínhamos, ao jeito "brincalhão" como eu lidava com as crianças e porque fiz propostas que envolviam trocas em grupo, como se verá, que tornaram a tarefa mais interessante. Uma idéia alternativa para a realização da revisão, que dessa vez infelizmente não cheguei a experimentar, é oferecer oportunidade para que os erros cometidos num determinado texto sejam
} 
cada um trabalhando em seu próprio texto, até que todos terminassem; então faríamos a roda para ler todas as histórias.

\section{OFICINA 22: REVISÃO EM GRUPO (13/05/98)}

Guiei um "passeio imaginário" pelo corpo, muito rápido, pois já havíamos começado a oficina com um certo atraso.

Expliquei o "código" que tinha utilizado para marcar nos textos o que precisava ser corrigido (vermelho indicando a necessidade de uma correção ortográfica e azul para outros tipos de alterações). As crianças começaram a fazer perguntas sobre seus erros e comecei a respondê-las em grupo, escrevendo na lousa a palavra tal como se encontrava no texto e perguntando se alguém sabia 0 que precisava ser alterado. Decidi então formar uma "roda" com as carteiras e propus que fizéssemos a leitura dos textos, seguida dos comentários dos colegas e esclarecimentos quanto às correções. Pedi que ouvissem a leitura do colega sem interromper e fizessem comentários depois. Esta atividade despertou bastante o interesse das crianças (contrastando com o que havia ocorrido na oficina anterior): todos ficaram atentos à leitura dos colegas (na maior do tempo; alguns não "resistiram" a dar umas olhadas no próprio texto...) e houve muita troca: perguntavam sobre passagens pouco claras, davam sugestões etc. $\AA^{1}$

\footnotetext{
"resgatados" numa outra produção. Ou seja, mostrar onde tais erros aconteceram, pontuá-los, criar situações (de preferência grupais) para que eles possam ser percebidos e corrigidos e a seguir fazer uma nova proposta de redação, chamando a atenção para que se procure não repetir aqueles mesmos erros. Depois de uma série de produções, pode-se voltar às primeiras e, provavelmente, a própria criança terá condições de fazer uma revisão sozinha - mesmo porque terá, então, tomado uma distância em relação à produção. Um distanciamento certamente sempre nos ajuda a "descolar" daquilo que produzimos e percebê-lo melhor.

1 “(...) a evolução da razão depende estreitamente de fatores sociais e (...) a contribuição hereditária ou adquirida não basta para conduzir por si só as inteligências individuais ao nível racional. Ora, é precisamente este dado fundamental da psicologia do pensamento que os professores da pedagogia reencontraram quando, depois de haverem estabelecido que a criança não é passiva mas ativa e que a razão, longe de ser inata no indivíduo, se elabora pouco a pouco, descobriram que a vida do grupo é o meio natural dessa atividade intelectual e a cooperação o instrumento necessário para a formação do pensamento racional.

Tocamos aqui a carne viva do problema. Se é exato que a cooperação é indispensável à elaboração da razão, o método do trabalho em equipes aparece como fundado sobre os mecanismos essenciais da psicologia da criança. Senão, ele não pode pretender outra coisa mais do que constituir um coadjuvante cômodo para a ação do mestre sobre o aluno.” (PIAGET, Jean. O trabalho em equipes na escola. p. 4)
} 


\section{OFICINA 23: REVISÃO EM GRUPO (17/06/98)}

Obs.1: Graziela e Maiara faltaram.

Obs. 2: Devido a questões diversas (uma falta minha, greve na escola, "provão" e jogo do Brasil na Copa), ficamos quatro semanas sem ter oficina.

Mais uma vez começamos atrasados, pois algumas crianças chegaram um pouco tarde e ficaram retidas na portaria, devido a uma nova norma, da qual eu ainda não estava inteirada... Enfim, optei por não fazer nenhuma atividade corporal.

As crianças sentaram-se à volta de uma mesa grande e fiquei à lousa. Fizemos então a correção coletiva de cada texto, da mesma forma que no começo da oficina anterior. Aqui também todos participaram muito.

Depois, cada um ficou corrigindo seu texto, consultando, às vezes, o dicionário ou os colegas. Cada um, ao terminar seu texto, chamava-me e líamos todo o texto juntos, observando outras questões que merecessem atenção, especialmente a pontuação.

Dispensei de comparecer à oficina seguinte as crianças que já tinham terminado a revisão do texto (Celso, Pedro e Talita).

Conversamos um pouco sobre a festa de encerramento, em que faríamos o lançamento do livro. Pensamos em marcar uma pizza à noite, para que os pais pudessem estar presentes, e ficaram de sondar as possibilidades em suas casas. Comprometi-me a telefonar para quem não tinha comparecido para falar do assunto. 
OFICINA 24: REVISÃO EM GRUPO (24/06/98)

Obs.: Celso, Pedro e Talita haviam sido dispensados; estes não compareceram, mas aquele quis ir.

Esta oficina foi muito semelhante à anterior. Esclareci algumas questões de ortografia à lousa, coletivamente, e outras individualmente, procurando discutir trechos específicos em que houvesse dificuldade para encontrar uma solução. Celso ficou ajudando as colegas a corrigir seus textos, dando palpites, procurando palavras no dicionário.

\section{OFICINA 25: REVISÃO EM GRUPO (01/07/98)}

Obs.: Graziela faltou.

As crianças confeccionaram objetos com sucata e materiais plásticos diversos para ilustrar o texto no livro. Propus que procurassem não fazer bonecos, mas sim objetos que remetessem a alguma idéia presente no texto; no entanto, a maioria não seguiu esta proposta e quis representar algum personagem de sua história. Todos se envolveram com a atividade.

Os objetos foram fotografados.

No final, combinamos quem traria o quê para a festa.

\section{FESTA DE ENCERRAMENTO (08/07/98)}

A idéia de marcar um encontro à noite para que os pais pudessem comparecer não vingou. Fizemos uma festinha na escola mesmo, no horário normal das oficinas. Apenas a mãe de Graziela, parturiente, não compareceu. Vieram também alguns irmãos de participantes das oficinas. Cada "família" trouxe um doce, salgado ou refrigerante, conforme havíamos combinado previamente. 
Quando todos já haviam chegado e se acomodado, fiquei de pé ao lado da mesa onde tinha colocado os livros e anunciei que estávamos, naquele dia, "lançando" o livro que tínhamos feito nas oficinas deste ano. Chamei todas as crianças ao mesmo tempo para que cada um pegasse o seu exemplar. Agradeci pela presença delas e também às mães, sem cujo apoio o trabalho não teria sido possível. A coordenadora de terceira e quarta séries, com quem eu havia conversado antes de iniciar o trabalho, compareceu à festa e agradeci também a ela por ter aberto as portas da escola para que esta experiência pudesse ser realizada. Ela quis pronunciar-se, elogiou o trabalho feito, agradeceu a mim, às crianças e às mães.

Depois fomos aos comes e bebes, tiramos fotos, batemos papos etc.

\section{V.4.c.iii) Os textos produzidos}

Foram observados nos textos produzidos pelas crianças os seguintes aspectos:

- adequação à proposta feita

- encadeamento ${ }^{1}$

- quando a proposta era escrever uma história, vale também como critério a presença ou ausência da estrutura dos contos populares de magia abordada nas oficinas, ou seja: a fórmula simplificada. A presença ou ausência dos temas e funções (Propp) típicos de tais contos não foi considerada, já que não chegou a ser trabalhada.

\footnotetext{
${ }^{1}$ Verbete: encadeamento

[De encadear + -mento.]

S. m.

1. Dependência de coisas homogêneas; conexão, união, encadeação, concatenação.

2. Sucessão ou seriação de idéias, de fatos, que tenham correlação: Naquele inverno houve um encadeamento de desgraças. (BARROSO, Márcio - Dicionário Aurélio Eletrônico)
} 


\section{Estudo de um caso}

Neste item apresentarei os textos produzidos por Celso comentados um a um, para que o leitor possa acompanhar de perto a evolução da escrita de uma das crianças no decorrer das oficinas. Optei por não fazer o mesmo com todos os outros textos por considerar que estes podem ser agrupados numa análise geral; além do que, uma análise caso a caso poderia se tornar muito longa e cansativa para o leitor.

Antes de freqüentar as oficinas, Celso (segundo seu próprio depoimento e também de sua mãe e de sua professora) tinha muita dificuldade para escrever nas palavras desta última, "não produzia nada" - e hoje se encontra em situação bastante diferente. Pode-se observar, neste item, como a produção dele ao longo das oficinas corrobora estas afirmações.

Os textos serão comentados com base nos aspectos mencionados no item anterior.

Todos os textos estão adequados à proposta feita (novamente, aqui, a única ressalva é a de que o texto 6 tende mais para a paráfrase criativa), de modo que os comentários referir-se-ão apenas ao aspecto "encadeamento" e presença ou ausência da estrutura dos contos populares de magia abordada nas oficinas.

\section{Celso: TEXTO 1 (Oficina 1)}

\section{Encontro com o personagem}

O perssonagem é uma fada de olhos castanhos.

E ela apareceu no meu cuarto eu tinha pensado que minha mãe assendeu a luiz eu perguntei o nome dela e ela disse:

- Graziela.

Eu quando eu olhei para traz e o eufo marido da fada apareceu e brigou com ela e eu perguntei o melhor amigo dela e ele disse Kian.

eu também é meu amigo também e brigam pela fada e pelo meu amigo.

O texto apresenta problemas sérios de encadeamento, como se pode observar especialmente nas últimas duas frases. Faltam partes que prejudicam o 
entendimento, como em "eu também é meu amigo (quem é amigo de quem?) e brigam pela fada e pelo meu amigo" (quem briga?). Também não ficamos sabendo por que o marido da fada briga com ela e por que esse "melhor amigo" entra na história. Parece que há dois amigos brigando por uma fada...

\section{Celso: TEXTO 2 (Oficina 2)}

\section{O Elfo contou!}

Ele veio na minha casa aquele dia e brigou co migo.

$\mathrm{O}$ gato que meu vizinho tem apareceu em minha casa o elfo drrepente ficou bonzinho.

Ele disse que um dia ele foi falar com os amigos deles e eles o ignoraram, ele fez de tudo, ritual magia e tudo então ele deu um susto com um desaparecimento de uns sapos mais conhecidos eles foram falar com o elfo ignoro os, e devouvelo sapo e nunca mais falou com eles.

Aqui também há problemas sérios. $\mathrm{O}$ fato de $\mathrm{o}$ aparecimento do gato ter feito o elfo ficar bonzinho é compreensível, pois acontecia algo parecido na história "O gato, o mago e o príncipe" (ANEXO 1), narrada na primeira oficina. No entanto, o texto não é auto-suficiente, pois o leitor que não conhecer esta história não compreenderá por que o elfo ficou bonzinho quando o gato apareceu.

O parágrafo seguinte é incompreensível a partir do desaparecimento dos sapos. As idéias não encontraram expressão adequada por escrito, apresentando-se desconexas, não encadeadas, o que prejudica a compreensão. O trecho está confuso, embora dê para entender que houve uma briga e no final os sapos foram devolvidos.

Há uma desconexão também entre as idéias apresentadas nas diferentes partes do texto: no início, o elfo briga com Celso, depois fica bonzinho e começa a contar sobre como foi ignorado pelos amigos e se vingou deles com 0 desaparecimento de uns sapos... 
Celso: TEXTO 3 (Oficina 3)

\section{O elfo que não era bem elfo}

Era uma vez um elfo que se chamava Celpelfou. Ele não respeita as ordens do magnífico mestre dos elfos o Poderifol e gostava de se transformar em outras coisas.

O Celpelfou adorava aprontar com crianças a noite.

Uma noite o elfo pulou a janela de uma casa e caiu em cima de uma menina... ele se transformou em uma flor brilhante e a menina o adorou, prendeu em o seu cabelo e o elfo nunca conseguiu sair.

Este texto foi produzido em dupla com Pedro. Está bem encadeado, perfeitamente concatenado, tanto no que se refere aos parágrafos, isoladamente, como ao conjunto deles: a idéia apresentada no início (de que o elfo gostava de se transformar em outras coisas) concretiza-se no final, em que ele se transforma em flor e passa a viver preso ao cabelos de uma menina.

Celso: TEXTO 4 (Oficina 4)

\section{Meu encontro com o monstro}

Foi bem legal eu fui vendo as jaulas vi o urço, a onça, o elefante, pedi uma carona para a girafa e fui bem na cabeça dela fui vendo de la de cima até que eu vi uma coisa estranha. Fui ver o que era a girafa abaixou a cabeça e eu fiquei bem perto dele, eu olhei muito achei muito estranho.

Fui berguntar uma coisa pra ele e ele viu os meus dentes... ele saiu correndo fugindo de mim eu pedi para ele parar mas ele não quis.

Descrição

- Ele era rosa

- Bem feio

- Mais muito cimpatico

- E medroso

- tinha so um olho

- e tinha o oho na barriga

- E a boca bem grande na cabeça

- Quando andava fazia um barulho de agua corrente

Ele era muito feio eu acho mas bem bonitinho para um monstro 
fiquei com bastante dó dele.

Sinceramente fiquei com muito medo de andar de girafa.

O texto está bem encadeado e contém uma surpresa: o passeio na cabeça da girafa. O susto do monstro não é tão surpreendente, pois na música que ouvimos o monstro também tem medo do dente da princesa.

Celso: TEXTO 5 (Oficina 5)

a) cardápio 1 : comidas nojentas

Restaurante ranho

CARDAPIO

SOBREMESA

- cocô com açucar

- musse de cerebro

- nariz com ranho

- coraça a mila nesa

\author{
ALMOÇO \\ - Fígado passado \\ - Fígado mal passado \\ - cocô duro e com sal \\ - tripa com cocô ralado \\ serebro rechiado com merda
}

- chifre de touro com sangue

PRATO ESPECIAL

- pessoa viva com açucara

b) cardápio 2: comidas gostosas

$$
\begin{aligned}
& \text { - nugets } \\
& \text { - macarrão } \\
& \text { - pizza } \\
& \text { - nhoque } \\
& \text { - sopa } \\
& \text { SOBREMESA } \\
& \text { - sorvete } \\
& \text { - bolo } \\
& \text { - musse } \\
& \text { - pudim }
\end{aligned}
$$

Do ponto de vista do encadeamento, o que se pode observar nestas listas 
de "alimentos" (que normalmente compõem um cardápio, não necessariamente acompanhadas de uma narrativa ou outro tipo de texto) é que estão agrupados elementos com características comuns: almoço de uma lado, sobremesa de outro.

Celso: TEXTO 6 (Oficinas 10 a 13)

\section{Hercules e seus amigos}

Era uma vez um elfo chamado Hercules e sua querida amiga fada chamada Suzi.

Um dia eles estava fazendo um piquenique em um bosque encantado e escutaram um barulho atras de uma moita.

- CHIC!! CHIC!! CHIC!!

Quando eles foram olhar, derrepente... saiu um coelho correndo e gritando:

- Estou atrasado!!!!! Estou atrasado!!!!!

Os dois curiosos, perguntaram:

- ATRASADO?

- SIM!! SIM!!

- PARA ONDE VOCÊ IRIA VOCÊ É SÓ UM COELHO?

- NÃO POSSO FALAR AGORA, ATÉ MAIS

Os dois muito curiosos seguiram ele.

Em um lugar muito distante havia uma menina chamada Alice e uma senhora que estava contando uma estoria para a Alice, a estoria estava tão canssativa que a Alice foi passear no bosque.

FIM DO 1 CAPITULO

No bosque Alice estava brincando quando viu passar um coelho, uma fada e um elfo, ela tão curiosa seguiu os três até uma toca de coelho e escura. Lá dentro tinha um grande buraco; o coelho mergulhou no buraco e os três também.

Quando estavam no fundo do buraco comecaram a flutuar e chegaram flutuando ate o chão.

FIM DO 2 CAPITULO

Chegaram em um lugar estranho cheio de coisas malucas.

Eles continuaram a seguir o coelho, que ainda estava gritando:

- estou atrasado, estou atrasado

Os três agarraram o coelho e olharam no relógio e disse para ele:

- Deve ser porque o relógio está parado

- pa-pa pa-parado

Rapidamente o coelho consertou o relógio e ensinou a eles a sair do 
pais das maravilhas.

FINAL

Há um bom encadeamento nesta narrativa. Como se trata de uma história, é preciso observar também se estão presentes os elementos da estrutura de conto trabalhada nas oficinas. Celso juntou personagens que conhecia (fada, elfo e personagens de Alice no país das maravilhas) numa história que apresenta três momentos (divididos em três capítulos), podendo-se perceber a presença de uma situação inicial a partir da qual se desenvolve uma narrativa que desemboca num desfecho. No entanto, não fica muito claro qual é o problema da história. Pode-se considerar que este era a aflição do coelho atrasado, que se resolve quando ele conserta o relógio, configurando-se um típico desenlace. À primeira vista, pode-se pensar que há uma inconsistência neste final, pois o fato de o relógio estar parado não parece fazer muito sentido como desencadeador da crença de estar atrasado. Porém, o fato de o coelho não se dar conta de estar vendo no relógio sempre a mesma hora (apesar de saber consertar relógios) é um nonsense perfeitamente aceitável - em se tratando de um "lugar estranho cheio de coisas malucas".

Celso: TEXTO 7 (Oficinas 16; 18 a 25)

Era uma vez um grande cavaleiro muito forte que morava perto de um reino. O nome dele era Romeu.

Um dia ele saiu de sua casa de cavalo para ir ao reino converçar com o rei. Ele tinha uma grande ave, faucão, ela mandava mensagens quando acontecia alguma coisa.

No caminho ele foi levado por uma bruxa muito feia, para um castelo arrepilante.

Romeu conseguiu uma folha e escreveu uma carta e amarrou na pata da ave, a ave saiu voando e entrou no castelo onde deixou a carta para o rei. $\mathrm{O}$ rei entendeu o pedido de socorro e chamou o poderoso e desengonssado Merven para duelar a bruxa.

(continuação do texto, sem alteração do que havia sido escrito)

$\mathrm{O}$ merven e a bruxa conversaram por telepatia as regras do duelo 
magico, não podia virar animais.

O prêmio por isso não e nenhum, só... a vida.

E quem perder não acontece nada só... morre.

Celso,

Procure saber, no exercicio de imaginação que vamos fazer, por que a bruxa resolveu raptar o cavaleiro. Tome cuidado também para não se esquecer dele, que é $\sigma$ protagonista da históría. $\mathcal{O}$ mago foi chamado para salvá-lo, não é? O que você escreveu até agora está bem legal, não jogue nada fora; apenas lembre-se de unir as coisas, devolvendo ao protagonista $\sigma$ papel de "centro das atenções". Beijo! Andrea

Era uma vez um grande cavaleiro muito forte que morava perto de um reino chamado THUITHUI THUMCRAEM. O nome dele era Romeu.

Um dia ele saiu de sua casa de cavalo para ir ao reino converçar com o rei. Ele tinha uma grande ave, faucão, ela mandava mensagens quando acontecia alguma coisa.

No caminho ele foi rapitado por uma bruxa muito feia (porque já atrapalhou a vida da bruxa muitas vezes), para um castelo arrepilante e ficou preso na masmorra.

Romeu conseguiu uma folha e escreveu uma carta e amarrou na pata da ave, a ave saiu voando e entrou no castelo onde deixou a carta para o rei. $\mathrm{O}$ rei entendeu o pedido de socorro e chamou o poderoso e desengonssado Merven para duelar a bruxa.

O merven e a bruxa conversaram por telepatia as regras do duelo magico, não podia virar animais.

O prêmio por isso não e nenhum, só... a vida.

E quem perder não acontece nada só... morre.

No duelo so se escutava: PLIM, PLIM, PLIM, PLIM!

Quando de repente a bruxa se transformou em um dragão. A bruxa, dragão, prendeu o Merven e tirou o chapeu dos poderes. O Merven fez uma concentração e tirou o cavaleiro da masmorra. Silenciosamente o cavaleiro atacou a faca nas costas da bruxa, soltou o mago Merven e eles viveram felizes para sempre.

Este texto será comentado e revisado na próxima oficina. Mesmo ainda não estando em sua forma final, no entanto, já é possível observar a presença dos componentes da narrativa de conto de fadas (fórmula simplificada). Nota-se também que o texto está encadeado; não há trechos desconexos ou incompreensíveis, como se podia ver nos primeiros textos. A melhora da escrita de Celso é comemorada por sua orgulhosa mãe, que relatou-me ao telefone o resultado de um trabalho feito numa aula de História: tratava-se de escrever uma 
autobiografia. Recebeu um retorno positivo do professor, segundo o qual Celso atingiu completamente o objetivo da tarefa.

A partir da oficina seguinte, passei a levar o texto digitado, com as palavras que deveriam ser corrigidas em vermelho (questões de ortografia) ou azul (outras questões). Aqui, apresento estas palavras todas em negrito, para facilitar a reprodução do texto. Sobre o texto digitado eram feitas anotações, com uso de asteriscos, flechinhas etc.

\section{Romeu e seus amigos}

Era uma vez um grande cavaleiro muito forte que morava perto de um reino chamado THUITHUI THUMCRAEM. O nome dele era Romeu.

Um dia ele saiu de sua casa de cavalo para ir ao reino converçar com o rei. Ele tinha uma grande ave, faucão, ela mandava mensagens quando acontecia alguma coisa.

No caminho ele foi rapitado por uma bruxa muito feia e foi levado para um castelo arrepiante e ficou preso na masmorra. A bruxa resouveu rapitar Romeu por que ele a tinha atrapalhado a roubar* o coração do rei que era sua principal meta.

Romeu por sorte achou uma folha e uma caneta no seu bousso, escreveu uma carta e amarrou na pata da ave, a ave saiu voando e entrou no castelo onde deixou a carta para o rei. $\mathrm{O}$ rei entendeu o pedido de socorro e chamou o poderoso e desengonssado Merven para duelar a bruxa.

O merven e a bruxa conversaram por telepatia as regras do duelo magico, não podia virar animais.

O prêmio por isso não era nenhum, só... a vida.

E quem perder não acontecia nada só... morre.

No duelo so se escutava: PLIM, PLIM, PLIM, PLIM!

Quando de repente a bruxa trapaciou se transformou em um dragão. 
A bruxa, dragão, prendeu o Merven mas esqueceu de tirar o chapeu dos poderes. O Merven fez uma concentração e tirou o cavaleiro da masmorra. Silenciosamente o cavaleiro atacou a faca nas costas da bruxa, soltou o mago Merven e eles viveram felizes para sempre.

Celso,

Faça uma revisão do seu texto, prestando atençã o a o seguinte:

1 - Algumas vírgulas podem (e devem) ser substituidas por pontos finais.

2. As palauras em vermetho estão com algum probleminha de ortografía e $\sigma$ que está em azul também precisa sofrer algum tipo de modificação - procure descobrir o que deve ser alterado e corrigir.

Berjoda Andrea.

*Você escreveu "tinha atrapathado a roubar", talvez pensando no verbo ajudar - quem ajuda, ajuda alguém a fazer algo. No entanto, $\sigma$ verbo atrapathar não pede preposição " $a$ ". Então é preciso mudar: "tinha atrapalhado quando tentou roubar" ou algo assim.

Versão final:

Romeu e seus amigos

Era uma vez um grande cavaleiro muito forte que morava perto de um reino chamado THUITHUI THUMCRAEM. O nome dele era Romeu.

Um dia ele saiu de sua casa de cavalo para ir ao reino conversar com o rei. Ele tinha uma grande ave, um falcão, que mandava mensagens quando acontecia alguma coisa.

No caminho ele foi raptado por uma bruxa muito feia, foi levado para um castelo arrepiante e ficou preso na masmorra. A bruxa resolveu raptar Romeu porque ele a tinha impedido de roubar o coração do rei, que era sua principal meta.

Romeu por sorte achou uma folha e uma caneta no seu bolso, escreveu uma carta e amarrou na pata da ave. Ela saiu voando e entrou no castelo, onde deixou a carta para o rei. Ele entendeu o pedido de socorro e chamou o poderoso e desengonçado Merven para duelar com a bruxa.

O merven e a bruxa conversaram por telepatia as regras do duelo mágico: não podia virar animais.

O prêmio por isso não era nenhum, só... a vida.

E quem perdesse, não acontecia nada, só... morria.

No duelo só se escutava: PLIM, PLIM, PLIM, PLIM! Quando de repente a bruxa trapaceou e se transformou em um dragão. A bruxa, dragão, prendeu o Merven mas esqueceu de tirar dele o chapéu dos poderes. O Merven fez uma concentração e tirou o cavaleiro da masmorra. Silenciosamente o cavaleiro atacou a faca nas costas da bruxa, soltou o mago Merven e eles viveram felizes para sempre.

Como se pode ver, o belo texto final de Celso coroa o que já se podia prever na primeira versão: um encadeamento perfeito, com a presença dos elementos básicos do conto de magia. 


\section{Análise genérica dos outros textos}

Neste item serão apresentados textos feitos por Gabriela, Graziela, Maiara, Pedro e Talita nas oficinas, no intuito de mostrar as diferentes soluções encontradas por eles a cada proposta. Pode-se fazer a seguinte análise dos textos, de forma geral: todos eles estão adequados ao que foi pedido, a não ser pelo fato de que algumas crianças terem realizado exercícios de paráfrase em momentos nos quais a proposta era inventar uma história (por exemplo, o texto 6 de Graziela, parece uma cópia ligeiramente modificada: ela disse ter "mudado um pouco" uma história que lera). As maioria das histórias escritas a partir da proposta feita no final de 97 (texto 6) apresenta os componentes da fórmula simplificada trabalhada nas oficinas - situação inicial; problema e acontecimentos em redor deste; desenlace.

Do texto 6 apresento somente a última versão, pois infelizmente, por um mal entendido, algumas crianças jogaram fora o esquema e a primeira versão quando os levaram para casa para passar a limpo o texto final.

Quanto ao texto 7, que foi para o livro, pode-se ter uma idéia de como foi todo o processo, da primeira versão até a última. Todos os textos me pareceram, além de encadeados e adequados à proposta feita, muito bonitos. "Corujice"? Não creio; acho que estão bonitos, mesmo...

\section{Gabriela: TEXTO 1 (Oficina 1)}

Eu estava em casa, quando tocou o telefone, atendi e marquei um encontro com uma pessoa, chegando lá era um moço (Elfo) perguntei varias coisas depois fui embora.

Perguntei seu nome, seu melhor amigo, seu pior inimigo, o que ele gostava de fazer e ele me respondeu que seu nome era Helio ele não tinha melhor amigo e seu pior inimigo também não tinha, ele gostava de passear na floresta, e de vijiar a fada.

\section{Gabriela: TEXTO 2 (Oficina 2)}

Eu era uma menina normal que estudava na escola Lidin, a profa. 
Pediu $\mathrm{p} /$ gente fazer em triu um teatro com qualquer tema, eu fui $\mathrm{p} /$ casa escrever em meu diário, derepente saiu de lá uma fada ela viu que eu estava pensativa e falou que eu podia me transformar em qualquer personagem por um dia por isso eu falei que o teatro era em trio e começava em meia hora, ela falou que eu podia ficar despreocupada, que quando estivermos entrando no palco ela nos transformava em personagens e nos dava alguma idéia liguei para meus amigos e falei o que tinha acontecido.

\section{Gabriela: TEXTO 3 (Oficina 3)}

Eu era uma menina normal, que brincava muito com minhas amigas, tinha 14 anos e chamo Juliana.

Certo dia estava brincando com minhas amigas, de repente apareceu um ser meio estranho, era um elfo; ele dizia que eu era a garota de seus sonhos e queria namorar comigo; eu falei que já tinha namorado, ele falou que não tinha importância, pois disputava meu amor com Rick, meu namorado. Então perguntou, que esporte ele gostava, respondi que era corrida.

Ele foi imediatamente à procura de Rick, e disputaram uma corrida, Rick ganhou, a 2a também, a terceira o ganhador, podia fazer qualquer pedido. Elfo se fez de esperto e correu pra valer e ganhou, seu pedido foi Juliana, então Rick se conformou, alguem ganha e alguem perde.

\section{Gabriela: TEXTO 4 (Oficina 4)}

Eu estava no zoologico, quando dei de cara com um ser meio esquisito quando percebi era um monstro, ele era todo branco com dois olhos arregalados, cheio de pelos pelo corpo, com uma bola preta no meio da barriga ele falava gregre meu nome é GURIX, vim do planeta briga, todo mundo era bruto e brigava, eu era o único que não brigava, na verdade sou do planeta Calmo, lá todos eram calmos como eu, amanhã vou para lá, com a ajuda de funcionários daqui. Fui embora p/ casa. 
Gabriela: TEXTO 5 (Oficina 5)

Cardápio 1: comidas nojentas

Café da manhã

Chá de meleca á larvas

bolachas crocantes de gosma gelada

pão com larvas

leite podre amarelado com pó de meleca

pão de meleca a molho de mingau gelado e para acabar

bolacha de chococo

Cardápio 2: comidas gostosas

Lasanha com frango

suco de laranja (fresco)

sobremesa (sorvete ou musse)

Gabriela: TEXTO 6 (Oficinas 10 a 13)

\section{Mario: o bagunceiro}

Mario era um menino de 8 anos, ele vivia aprontando com todo mundo, principalmente com sua irmã mais nova de 6 anos, eles tinham pais separados e viviam com a mãe.

Certo dia Mario falou pra Aline:

- Aline! Pede dinheiro pra mamãe, a gente compra bala sorvete e um monte de doce! - Mas Aline não era boba e disse:

- Pede você, que conhece ela a mais tempo! - Mario ficava furioso com as respostas da irmã.

Sua mãe ouvindo o diálogo entre os dois, chamou Mario em um canto e falou:

- Mario, não seja tão bagunceiro, por que você não se organiza? Você já vai repetir de ano na escola, pela sua bagunça - mas Mario não escutava e falava baixinho:

- Cala a boca, eu não vou repetir de ano na escola não! - no final do ano o que aconteceu? Ele repetiu de ano!

Dai em diante ele lembrou do que a mãe tinha dito e pensou: "Será que não é melhor fazer as coisas corretas? Sei que irá dar trabalho, mas é melhor fazer $1 \mathrm{vez}$ as coisas certas, do que 2 vezes erradas" Ele terminou 
os estudos sem repetir nem um ano, cresceu se tornou um empresário e agradeceu muito a mãe, porque se não fosse ela, hoje ele não seria alguém na vida, estaria desempregado ou como lixeiro.

\section{Gabriela: TEXTO 7 (Oficinas 16; 18 a 25)}

Era uma vez numa cidade muito calma uma dançarina que fazia shows, muitos shows em um deles ela conheceu um andarilho e se apaixonou.

O problema é que ela era casada e ama seu marido, mas a sorte é que ela ainda não tem filho, ao chegar em casa, conversou com seu marido ele não entendeu nada pois ela era tão apaixonada, dançava todas as noites $\mathrm{p} /$ ele, cansada ou não cansada e agora ela vem e diz que tudo acabou, segurando seu choro ele saiu de casa.

(continuação do texto, sem alteração do que havia sido escrito)

No outro dia ela saiu de casa, sua cabeça estava nas nuvens e adivinha com quem ela trombou? Com o andarilho. Imediatamente ela disse:

- Me desculpe, pois eu estava tão distraída e não lhe vi.

- Não, não foi nada.

Gabi,

Como a proposta é escrever um conto de fadas, procure introduzir na sua história um personagem fantástico (coadjuvante ou antagonista), como por exemplo uma fada, uma bruxa etc. Talvez você consiga "descobrir" quem será este personagem no exercício de imaginação que vamos fazer. Béjo! Andrea

OBS.: Coloque todos of verbos no passado: ... amava seu marido, mas a sorte era que ela ainda não tinha fitho..." "A sorte era" fica meio esquisito, né? Experimente trocar: "por sorte ela ainda não..."

Era uma vez numa cidade muito calma chamada Calmolândia uma dançarina que fazia shows, muitos shows em um deles ela conheceu um andarilho e se apaixonou.

O problema é que ela estava casada e amava seu marido, por sorte ela ainda não tem filho, ao chegar em casa, conversou com seu marido ele não entendeu nada pois ela era tão apaixonada, dançava todas as noites $\mathrm{p} /$ ele, cansada ou não cansada e agora ela vem e diz que tudo acabou, segurando seu choro ele saiu de casa.

No outro dia ela saiu de casa, sua cabeça estava nas nuvens e adivinha com quem ela trombou? Com o andarilho. Imediatamente ela disse:

- Me desculpe, pois eu estava tão distraída e não lhe vi. 
- Não, não foi nada.

- Pra me sentir perdoado você vai ter que aceitar meu convite de ir em minha casa tomar um cafezinho.

- Eu aceito seu convite pois não tenho nada pra fazer mesmo não pense que isso é um desprezo, é só um aviso para que o encontro seja prolongado!

Chegando em casa após o café eles foram ao cinema, tomaram sorvete, conversaram muito e ela lhe disse:

- Sabia que você faz meu tipo - Ele retrucou:

- Você também é a mulher ideal p/ mim.

Depois de um belo tempo de namoro, resolveram se casar, ao saber disso seu marido foi lá falar com ela:

- Agora entendi tudo você se separou tudo bem, mas que me trocasse por algo melhor, né?

- Olha aqui eu não disse que era pra você nunca mais voltar aqui?

- Olha aqui, eu ia lhe perturbar pro resto da vida.

Gabriela faltou à oficina em que levei pela primeira vez o texto digitado, tomando contato com ele (e portanto também com minhas observações por escrito) somente na oficina seguinte. Continuou escrevendo sua história enquanto fazíamos a leitura em grupo de todos os textos, sem deixar de participar um pouco da discussão.

Era uma vez numa cidade muito calma chamada Calmolândia uma dançarina que fazia shows, muitos shows em um deles ela conheceu um andarilho e se apaixonou.

O problema é que ela estava casada e amava seu marido, por sorte ela ainda não tinha filho, ao chegar em casa, conversou com seu marido ele não entendeu nada pois ela era tão apaixonada, dançava todas as noites p/ ele, cansada ou não cansada e agora ela vem e diz que tudo acabou. Segurando seu choro ele saiu de casa.

No outro dia ela saiu de casa, sua cabeça estava nas nuvens e adivinha com quem se deparou? Com o andarilho. Imediatamente ela disse:

- Me desculpe *, pois eu estava tão distraída e não lhe vi.

- Não, não foi nada.

- Pra me sentir perdoado você vai ter que aceitar meu convite de ir 
comigo em um baile e o mais chique da cidade.

- Eu aceito seu convite pois não tenho nada pra fazer mesmo não pense que isso é um desprezo, é só um aviso para que o encontro seja prolongado!

Chegando em casa após o baile eles foram pra casa dela dormiram no mesmo quarto. No dia seguinte foram ao bosque dar um passeio de carroagem, conversaram muito e ela lhe disse:

- Sabia que você faz meu tipo - Ele retrucou:

- Você também é a mulher ideal para mim.

Depois de um belo tempo de namoro, resolveram se casar, ao saber disso seu marido foi lá falar com ela:

- Agora entendi tudo você se separou tudo bem, mas que me trocasse por algo melhor, né?

- Olha aqui eu não disse que era pra você nunca mais voltar aqui?

- Olha aqui, eu ia lhe perturbar pro resto da vida, pois fiquei com muita raiva de vocês - no mesmo instante um príncipe jogou um feitiço sobre o ex marido, aí ele ficou bonsinho, bonsinho até $d+$, e disse:

- Já que foi sua decisão, que vocês vivam felizes para sempre e que só a morte os separe.

Ele saiu correndo e enquanto isso surgiu um convite:

- Você quer se casar comigo? - um feiticeiro malvado disse baixinho fale não, fale não, senão vai se arrepender. Ela ficou meio tonta, o seu namorado disse:

- O que foi se você acha cedo tudo bem, não precisa ficar assim.

- Não é isso, é que eu, sei lá, fiquei meio zonza, vai passar, rapidamente o príncipe jogou um feitiço sobre o outro feiticeiro $(\text { antagonista })^{* *}$, e o feitiço se quebrou,

Gabi,

A sua história ganhou britho com os acontecimentos mágicos que você inventou. No entanto, eles estão meio "soltos", pouco "amarrados": $\sigma$ leitor não entende "de onde surgiu" o príncipe que fez a primeira mágica - atiás, 
procure substitui-lo por um mago ou explique como foi que aconteceu de um principe de repente estar fazendo mágicas. Não se esqueça: os acontecimentos da história precisam estar encadeados, ligados um ao outro, como os elos de uma corrente.

Vou insistir: reveja todos os verbos e coloque todos no passado.

Faça uma revisão final do seu texto, prestando atenção ao seguinte:

1 - Algumas vírgulas podem (e devem) ser substituidas por pontos finais.

2- As palauras em vermetho estão com algum probleminha de ortografía e o que está em azut também precisa sofrer algum tipo de modíficação - procure descobrir o que deve ser alterado e corrigir.

Observação: Substitui todas as abreviações por palavras inteiras. Você já deve saber que é preciso fazer isto sempre que vamos apresentar um texto em sua forma final, né?

Berjo da Andrea.

* Ela pediu desculpas por quê? Na outra versão do texto, ela havia trombado com ele, mas depois você mudou o verbo para "deparar-se". As desculpas ficaram sem sentido...

** Essa explicação não deve vír no texto. A idéia de que um personagem é antagonista deve fúcar clara através de sua caracterização e principalmente de suas ações.

Era uma vez uma cidade muito calma chamada Calmolândia. Nela vivia uma dançarina que fazia shows, muitos shows. Em um deles ela conheceu um andarilho e se apaixonou.

O problema era que ela estava casada e amava seu marido, mas por sorte ela ainda não tinha filho. Ao chegar em casa, conversou com seu marido sobre o andarilho. Ele não entendeu nada, pois ela era tão apaixonada, dançava todas as noites p/ ele, cansada ou não cansada. Segurando seu choro ele foi embora.

No outro dia ela saiu de casa, sua cabeça estava nas nuvens e adivinha com quem trombou? Com o andarilho. Imediatamente ela disse:

- Me desculpe, pois eu estava tão distraída e não lhe vi.

- Não, não foi nada.

- Pra me sentir perdoado você vai ter que aceitar meu convite de ir comigo em um baile e o mais chique da cidade.

- Eu aceito seu convite, pois não tenho nada pra fazer mesmo. Não 
pense que isso é um desprezo, é só um aviso para que o encontro seja prolongado!

Chegando em casa após o baile eles foram pra casa dela. Dormiram no mesmo quarto. No dia seguinte foram ao bosque dar um passeio de carruagem, conversaram muito e ela lhe disse:

- Sabia que você faz meu tipo? - Ele retrucou:

- Você também é a mulher ideal para mim!

Depois de um belo tempo de namoro, resolveram se casar, ao saber disso seu marido foi lá falar com ela:

- Agora entendi tudo. Você se separou, tudo bem, mas que me trocasse por algo melhor, né?

- Olha aqui! Eu não disse que era pra você nunca mais voltar aqui?

- Olha aqui, eu ia lhe perturbar pro resto da vida, pois fiquei com muita raiva de vocês! - no mesmo instante um príncipe jogou um feitiço sobre o ex marido, aí ele ficou bonzinho, bonzinho até $\mathbf{d +}+$, e disse:

- Já que foi sua decisão, que vocês vivam felizes para sempre e que só a morte os separe.

Ele saiu correndo e enquanto isso surgiu um convite:

- Você quer se casar comigo? - um feiticeiro malvado disse baixinho fale não, fale não, senão vai se arrepender. Ela ficou meio tonta, o seu namorado disse:

- O que foi se você acha cedo tudo bem, não precisa ficar assim.

- Não é isso, é que eu, sei lá, fiquei meio zonza, vai passar, rapidamente o príncipe jogou um feitiço sobre o mago mal, e o feitiço se quebrou, daí então ela disse sim, quero casar com você. Assim fizeram e viveram felizes para sempre.

Gabi,

Lembre-se de bolar um titulo para a sua história.

Como já disse, ela ganhou britho com of acontecimentos mágicos que você inventow. No entanto, eles estã $\sigma$ mei $\sigma$ "soltos", pouco "amarrados": $\sigma$ leitor não entende "de onde surgiu" o príncipe que fez a primeira mágica atiás, substitua-o por um mago ou explique como foi que aconteceu de um 
principe de repente estar fazendo mágicas. Não se esqueça: of acontecimentos da históría precisam estar encadeados, ligados um ao outro, como os elos de uma corrente.

Faça uma revisão final do seu texto, prestando atenção ao seguinte:

1- Ainda falta pontuar methor alguns trechos. Se você escothew $\sigma$ travessão para sinatizar as falas dos personagens, deve manter este padrão até o finat, usando sempre a mesma forma.

2. O que está em vermetho tem algum probleminha de ortografia e $\sigma$ que está em azul também precisa sofrer algum tipo de modificação - procure descotrir o que deve ser alterado e corrigir.

Observação: Substitua as abreviações por palavras inteiras. Acho que você tinha deixado assim porque era rascunho ainda - você já deve saber que é preciso escrever tudo por extenso sempre que vamos apresentar um texto em sua forma final, né?

Berjo da Andrea.

Versão final:

\section{Nem sempre a cidade Calmolândia é calma!}

Era uma vez uma cidade muito calma chamada Calmolândia. Nela vivia uma dançarina que fazia shows, muitos shows. Em um deles ela conheceu um andarilho e se apaixonou.

O problema era que ela estava casada e amava seu marido, mas por sorte ela ainda não tinha filho. Ao chegar em casa, conversou com seu marido sobre 0 andarilho. Ele não entendeu nada, pois ela era tão apaixonada, dançava todas as noites para ele, cansada ou não cansada. Segurando seu choro, ele foi embora.

No outro dia, ela saiu de casa. Sua cabeça estava nas nuvens e adivinha com quem trombou? Com o andarilho. Imediatamente ela disse:

- Me desculpe, pois eu estava tão distraída e não o vi!

- Não, não foi nada.

- Pra me sentir perdoado você vai ter que aceitar meu convite para ir comigo a um baile. E o mais chique da cidade.

- Eu aceito seu convite, pois não tenho nada pra fazer, mesmo. Não pense que isso é um desprezo, é só um aviso para que o encontro seja prolongado!

Chegando em casa após o baile, eles foram pra casa dela. Dormiram no mesmo quarto. No dia seguinte foram ao bosque dar um passeio de carruagem, conversaram muito e ela the disse:

- Sabia que você faz meu tipo? - Ele retrucou:

- Você também é a mulher ideal para mim!

Depois de um belo tempo de namoro, resolveram se casar, ao saber disso seu marido foi lá falar com ela:

- Agora entendi tudo. Você se separou, tudo bem, mas que me trocasse por algo melhor, né?

- Olha aqui! Eu não disse que era pra você nunca mais voltar aqui?

- Olha aqui, eu ia perturbá-la pro resto da vida, pois fiquei com muita raiva de vocês! - No mesmo instante a fada-madrinha do ex-marido, que estava investigando o caso desde o começo, jogou um feitiço sobre ele, aí ele ficou bonzinho, bonzinho até demais, e disse: 

separe.

- Já que foi sua decisão, que vocês vivam felizes para sempre e que só a morte os

Ele saiu correndo e enquanto isso surgiu um convite:

- Você quer se casar comigo?

Um feiticeiro malvado que passava por lá disse baixinho:

- Fale não, fale não, senão vai se arrepender. - Ela ficou meio tonta, o seu namorado disse:

- O que foi? Se você acha cedo tudo bem, não precisa ficar assim.

- Não é isso, é que eu, sei lá, fiquei meio zonza, vai passar.

Rapidamente a fada-madrinha jogou um feitiço sobre o mago malvado e o feitiço dele se quebrou, daí então ela disse:

- Sim, quero casar com você.

Assim fizeram e viveram felizes para sempre.

\section{Graziela: TEXTO 1 (Oficina 1)}

Meu nome e fada Lua

Gosta de passear na floresta

Melhor amiga fada Gabriela

inimigo mago

gosta de ajudar as pessoas

gosta de animais da floresta

O mago era muito chato e feio

lá na floresta tinhas ums grupos de fada que uma não gostava da outra

lá tinha uma fada chamada Fabiola que era muito chata

\section{Graziela: TEXTO 2 (Oficina 2)}

Um serto dia a fada lua estava paseando pela floresta quando viu um animal que cai na armadilha do duende ela o ajudou continuou seu passeio quando derrepente aparece o mago e diz

- Eu vou te derrotar - e a fada disse

- Não vai

Quando as outras fadas principalmente a fada Gabriela ouviram a discussão e foi ajuda a fada Lua todas pegaram sua varinha de condão e derrotaram o mago.

Só que no mesmo dia apareceu o duente e ela sozinha o derrotou e fez e;le virar sapo.

Esse dia foi munto cansativo não para ajudar e sim para derrotar os dois inimigos.

Graziela: TEXTO 3 (Oficina 3) 
Era uma vez uma fada chamada Violeta que um serto dia estava passeando na floresta quando encontrou um elfo chamado Oriom. Derrepente os dois sentiram uma coisa estranha, olharam bem no fudo dos olhos e quando viram estavam apaixonados.

Fada Violeta ficava desligada não dava a mínima para seus problemas sua companheira fada Margarida ficou muito preocupada e tentou descobrir o que tinha acontesido. Mas ela não queria falar.

Um serto dia o Oriom foi na floresta encantada conversar com Violeta, quando chegou lá Violeta ficou super feliz só que a noticia para ela não era munto legal o que ela não sabia. Oriom disse:

- Violeta eu não te amo mas achei um novo amor para minha vida.

Violeta ficou munto triste, logo depois que Oriom foi embora Violeta morreu, mas morreu de amor.

FIM

\section{Graziela: TEXTO 4 (Oficina 4)}

No dia 12/6/97 eu fui no zoloogico e vi varios animais, passei na jaula dos macacos e quase todos os animais, so que derrepente eu vi um animal estranho não dava para velo bem resouvi entrar na jaula vi esse animal era inofencivo tinha sua esposa e seu filhos.

Seus filhos não gostavam de adultos so de criança, fiquei brincando com seus filhos mas aquele não era um animal e sim um monstro ele era todo verde com alguns pelos mas a mulher dele era rosa é que monstros femia sam rosa e macho, verde.

Logo depois que sai so fiquei pensando naqueles monstros, também tirei fotos deles porque eles não eram um monstro mal e sim do bem.

O monstro come

so vegetal

ele não come humano

ele e munto legal

não é do mal 
Graziela: TEXTO 5 (Oficina 5)

Cardápio 1: comidas nojentas

Leite com gosma

pão com lesmas

lingua com gelelia

nariz com caquinha

ouvido com besouro

Café da tarde

Bolo com caquinha de nariz

Suco de xixi

Pão com gosma

Biscoito com cuspe

Leite com coco

Suco de abacaxi com gosma

Cardápio 2: comidas gostosas

Peixe ao molho

Lasanha

Franco assado

Macarrão com molho branco

Camarão

Amburgue

Inhoque

Carne cozida

Pizza

Pife com queijo

Pudim

Pave (com sonho de vausa)

Musse de chocolate 


\section{A longa vida de Merlim}

$\mathrm{Na}$ antiga cidade havia um lider guerreiro, temivel e violento, chamado Rafa.

Quando ele se viu atacado por outros povos e a ponto de ser derrotado, consultou bruxos em busca de ajuda. Este lhe disseram que escolhesse a mais linda criança da região e a matasse, oferecendo a vida dela em troca de uma vitoria.

A noticia se espalhou em varias familias esconderam seus filhos para que os soldados não os encontrassem. Mas havia na floresta um menino chamado Merlim, que nunca tinha medo de nada.

Certa manhã, vendo o sol bilar, ele saiu para pescar. Quando os soldados de Rafa avistaram o belo menino brincando no lago, correram para prendê-lo.

O pequeno Merlim foi deixado em um quarto por três longos dias. Depois foi conduzido a uma estranha reunião de homens e mulheres. Merlim logo percebeu que sua vida corria perigo. Porém, antes que o levassem para ser sacrificado, o menino soltou-se dos soldados, correu até Rafa e declarou:

- Antes que você ordene minha morte, e preciso que eu lhe diga certas coisas.

Espandado, o lider concordou em ouvilo.

- Sou um mago e assim nasci. Trago comigo os segredos dos ceus, terras e estrelas. Vejo em seus olhos e posso saber tudo sobre o que viveu e muito e muito do que está para lhe acontecer.

Rafa, assustado, resolveu testalo.

- Conte sobre o meu passado - ordenou.

Então Merlim revelo, diante de toda a crote, vários segredos que apenas o guerreiro conhecia. Pertubado o lider pediu-lhe:

- Agora fale sobre o meu futuro - o menino atendeu

- O futuro ainda depente de muitas de suas decisões. Se você me matar, morrerá também. A violência cada vez maior. Mas, se agir com calma e persistência, vencerá a guerra e seu nome nunca será esquecido.

Convencido, Rafa mudou sua estrategia, preferindo agir com prudencia. Quando percebeu que a guerra esta terminando, e que o menino tinha razão, convido o pequeno Merlim para ser seu conselheiro.

Nesse dia, Merlim inicio sua longa vida de sabio. Depois de Rafa acompanhou Beto, salvando seu filho Artur da mão de inimigos.

Artur cresceu sempre vigiado por Merlim, que se transforma em um passaro e animais da floresta para estar a seu lado. Quando Artur foi coroado rei da Tavola Redonda, pediu a Merlim que fosse seu conselheiro. E grande parte das vitorias do lendario rei Artur que liderava a Tavola 
Redonda foram inspiradas pela profunda sabedoria do velho mago, Merlim seu amigo protetor.

Graziela: TEXTO 7 (Oficinas 16; 18 a 25)

(trouxe de casa um esquema: "ficha do conto")

Personagens: Rainha grávida, e linda, feminina.

Sacerdote: muito responsavel, cuidadoso.

Dois cães bravos

Conflito: O sacerdote se apaixona pela rainha mas o problema e que ela ainda não gosta dele e eodeia animais e o sacerdote adora animais, então nós não sabemos se esse amor vai dar serto.

Resolução: O Sacerdote se casa com a rainha e um mês depois ela fica grávida. Mas ela ainda não está muito acostumada com os animais de sseu marido e muito menos com os dois cães bravos.

(produção em classe)

Era uma vez uma rainha chamada Bianca de 30 anos, ela e uma lindeza, e muito quieta e calma.

Num reino perto do da rainha Bianca, mora um sacerdote chamado Filipe que adora animais e ajuda a todos os animais que aparecem na sua porta machucado. Ele é apaixonado pela a rainha, mas ela ainda não conhece o sacerdote nem sabe que tem um perto dela.

Como o sacerdote e apaixonado pela rainha ele vai tentar de qualquer maneira conquistar seu coração.

Um certo dia os dois se encontraram os dois estavam tão bonitos que quando a rainha bateu os olhos no Sacerdote se apaixonou - e essa paixão era muito grande e os dois decidiram namorar.

(Na oficina seguinte, começou um novo texto)

Era uma vez uma rainha chamada Bianca que mora num reino muito distante da cidade das maravilhas, essa rainha sabe das coisas da vida e calma.

No reino vizinho vive um Rei Renam muito bonito de 30 anos que ama a rainha Bianca, ele também adora animais como a Bianca. Mas no outro reino mora um Sacerdote que ama a também a rainha só que ela não gosta dele.

Um certo dia teve um jantar no castelo do rei Renan e ele convidou a 
rainha, já no fim da festa quando a rainha foi se despedir-se do rei

Graziela,

Procure introduzir um personagem fantástico na sua história. Parece que você desistu da primeira idéia e quer escrever uma históría diferente da que tinha bolado quando escreveu a "ficha", mas pelo visto está aproveitando algumas idéias. Legal!

Lembre-se: $\sigma$ protagonista tem de ser DO BEM. Procure justificar of acontecimentos de forma que as coisas não füquem "meio jogadas" e sim "bem amarradas". Berjo! Andrea

(Graziela trouxe de casa o texto seguinte. Na oficina, li e fiz alguns comentários, a partir dos quais modificou algumas coisas: acrescentou um personagem fantástico e deixou de mencionar a idade dos personagens.)

Era uma vez uma rainha chamada Bianca que sabe muito da vida pois já teve muita experiencias no amor. Ela é apaixonada pelo um rei chamado Gustavo que mora no reino vizinho da rainha. Mas o que a rainha não sabe e que o rei gosta dela também e acha que isso vai dar em casamento. Mas tem um sacerdote metido nessa historia de amor que também e apaixonado pela rainha.

Um certo dia o rei Gustavo deu uma festa em seu reino, e convidou a rainha Bianca que aceitou o convite na hora, mas a festa era a fantasia.

$\mathrm{Na}$ hora da festa como estava quase todos de mascara menos o rei Gustavo e a rainha Bianca, mas o que ninguém sabia e que o sacerdote estava na festa e observando todos os passos da rainha. Mas lá tambem tinha uma fada mas ninguem sabia disso que poderia atrapalhar todos os planos do sacerdote.

No fim da festa como o rei e a rainha estavam namorando já quase noivos o rei pediu para a rainha dormir em seu reino mas ela não aceitou. Quando ela já estava saindo do reino o Sacerdote estava esperando-a atrás da arvore e claro sem ela saber. Derrepente o Sacerdote apareceu e começou a falar:

- Meu amor eu amo muito você e a rainha pensou que foce o rei e respondeu:

- Eu também amo. - Derrepente o Sacerdote sai de tras da arvore a começou a agarar a rainha, quando ela percebeu que não e o rei ela começa a gritar SOCORRO! Rapidamente veio a fada e sauvou o rei e ele junto e salvam a rainha desse Sacerdote mal carater, a rainha foi diretamente para o seu reino e queria ficar sozinha, chegou em seus aposento e dormiu como um anjo.

No dia seguinte quando Bianca acordou seu noivo Gustavo já estava lá para saber notícias de sua amada quando a rainha desseu para tomar 
café e viu seu noivo o rei e começaram a se beijar. Logo depois de terminarem de tomar café o rei Gustavo convidou a rainha Bianca para um jantar em seu reino e ela aceitou.

Já na hora de ir ao jantar a rainha colocou um vestido bem bonito e foi para o jantar, chegando lá o rei não estava pronto, mas quando ele deceu a rainha ficou emprecionada com a lindeza de seu noivo. Na hora do jantar eles estavão os dois sozinho mas não rolou nada.

Já no fim do jantar quando a rainha estava de saida o rei não a deixou ir e levou-a até seus aposentos e começaram a fazer amor a noite inteira.

No dia seguinte logo depois do café a rainha Bianca foi embora e ficou o dia inteiro pensando, na noite passada com o rei.

Se passaram um mês e a rainha descobriu que estava gravida quando foi dar a noticia para o rei eles decidiram marcaram a data do casamento.

No dia do seu casamento a rainha estava com nove meses e quase teve o bebe no casamento segundo dia mais feliz de sua vida.

Já se passaram uns quatro dias de seu casamento e no dia 15/6/87 sua filha nasceu em plena lua de mel ela se chama Lara

Quando a rainha e o rei chegaram no reino com sua filha princesa Lara, todos ficaram surpresos com a princesa, porque ela era tão bonita que quando crescer vai conseguir muito rápido varios pretendentes para se casar.

Se passaram meses e o rei e a rainha estavam muito chateado pois estavam quase separados. Mas no dia do aniversario de um ano da princesa Lara eles se reconsiliaram e viveram felizes para sempre e sempre.

A partir de então, passou a trabalhar sobre o texto digitado.

Era uma vez uma rainha chamada Bianca que sabia muito da vida pois já teve muita experiencias no amor. Ela é apaixonada pelo um rei chamado Gustavo que morava no reino vizinho da rainha. Mas o que a rainha não sabe e que o rei gosta dela também e acha que isso em augum dia vai dar em casamento. Mas tem um sacerdote metido nessa historia de amor que também é apaixonado pela rainha.

Um certo dia o rei Gustavo deu uma festa em seu reino, e convidou a rainha Bianca que aceitou o convite na hora, mas a festa era a fantasia.

Na hora da festa como estava quase todos de mascara menos o rei 
Gustavo e a rainha Bianca, e o sacerdote sem ser chamado estava na festa e observando todos os passos da rainha. Mas lá tambem tinha uma fada mas ninguem sabia disso que poderia atrapalhar todos os planos do sacerdote.

No fim da festa como o rei e a rainha estavam namorando o rei pediu para a rainha dormir em seu reino mas ela não aceitou. Quando ela já estava saindo do reino o Sacerdote estava esperando-a atrás da arvore e claro sem ela saber. Derrepente o Sacerdote apareceu e começou a falar:

- Meu amor eu amo muito você. A rainha pensou que foce o rei e respondeu:

- Eu também amo. - Derrepente o Sacerdote sai de trás da arvore e começou a agarar a rainha, quando ela percebeu que não era o rei ela começa a gritar SOCORRO! Rapidamente veio a fada salvou a rainha desse Sacerdote mal carater. Ela fez uma magica e desapareceu com o sacerdote e ele foi parar em um lugar muito distante dali. A rainha foi diretamente para o seu reino e queria ficar sozinha, chegou em seu aposento e dormiu como um anjo.

No dia seguinte quando Bianca acordou seu noivo Gustavo já estava lá para saber notícias de sua amada quando a rainha desseu para tomar café e viu seu noivo o rei e começaram a se beijar. Logo depois de terminarem o café rei Gustavo convidou rainha Bianca para um jantar em seu reino e ela aceitou.

Já na hora de ir ao jantar a rainha colocou um vestido bem bonito e foi para o jantar, chegando lá o rei não estava pronto, mas quando ele deceu a rainha ficou emprecionada com a lindeza de seu noivo. Na hora do jantar eles estavão os dois sozinho mas não rolou nada.

Já no fim do jantar quando a rainha estava de saida o rei não a deixou ir e levou-a até seus aposentos e começaram a fazer amor a noite inteira.

No dia seguinte logo depois do café a rainha Bianca foi embora e 
ficou o dia inteiro pensando, na noite passada com seu amor.

Se passaram um mês e a rainha descobriu que estava gravida quando foi dar a noticia para o rei eles decidiram marcaram a data do casamento.

No dia do seu casamento a rainha estava com nove meses e quase teve o bebe no casamento segundo dia mais feliz de sua vida.

Já se passaram uns quatro dias de seu casamento e no dia 28/6/87 sua filha nasceu em plena lua de mel ela se chama Lara

Quando a rainha e o rei chegaram no reino com sua filha princesa Lara, todos ficaram surpresos com a princesa, porque ela era tão bonita que quando crescer vai conseguir muito rápido varios pretendentes para se casar.

Se passaram meses e o rei e a rainha estavam muito chateado pois estavam quase separados, pois o sacerdote veio no meio dessa historia de amor e falou que a rainha tinha o traido. Mas no dia do aniversario de um ano da princesa Lara eles se reconsiliaram* e viveram felizes para sempre e sempre.

Grázi,

Falta dar um titulo para sua história e fazer uma revisão final do texto, prestando atenção ao seguinte:

1-Algumas vírgulas podem (e devem) ser substituidas por pontos finais. Dê uma othada no texto todo, veríficando onde faltam vírgulas e outros sinais de pontuação.

2. As palauras em vermetho estão com algum probleminha de ortografia e $\sigma$ que está em azul também precisa sofrer algum tipo de modificação - pode ser no tempo do verbo, na concordâncía etc. Descubra $\sigma$ que deve ser alterado e corrúa.

3- Grifei uma palavra que você repetur sem necessidade. Evite esse tipo de repetição, eliminando a palarra repetida sempre que possivel ou substituindo-a por outra equivalente.

Berjoda Andrea

* Procure explicar como foi a reconcitiação do casal. 
Versão final:

\section{Quando é amor de verdade podemos nos separar mas voltamos um para o outro}

Era uma vez uma rainha chamada Bianca que sabia muito da vida pois já tinha tido muita experiência no amor. Ela era apaixonada por um rei chamado Gustavo que morava no reino vizinho da rainha. Mas o que ela não sabia era que o rei gostava dela também e achava que isso algum dia ia dar em casamento. Mas tinha um sacerdote metido nessa história de amor que também era apaixonado pela rainha.

Um certo dia o rei Gustavo deu uma festa em seu reino e convidou a rainha Bianca, que aceitou o convite na hora. A festa era a fantasia.

$\mathrm{Na}$ hora da festa estavam quase todos de máscara, menos o rei Gustavo e a rainha Bianca. O sacerdote, sem ser chamado, estava na festa, observando todos os passos da rainha. Lá também tinha uma fada - mas ninguém sabia disso - que poderia atrapalhar todos os planos do sacerdote.

No fim da festa, como o rei e a rainha estavam namorando, o rei pediu para a rainha dormir em seu reino, mas ela não aceitou. Quando ela já estava saindo do reino, o sacerdote estava esperando-a atrás da árvore - é claro, sem ela saber. De repente o Sacerdote apareceu e começou a falar:

- Meu amor, eu amo muito você. - A rainha pensou que fosse o rei e respondeu:

- Eu também amo. - De repente o Sacerdote saiu de trás da árvore e começou a agarrar a rainha, quando ela percebeu que não era o rei, começa a gritar: - SOCORRO! Rapidamente veio a fada e salvou a rainha desse sacerdote mau caráter. Ela fez uma mágica e desapareceu com o sacerdote. Ele foi parar em um lugar muito distante dali. A rainha foi diretamente para o seu reino e queria ficar sozinha, chegou em seu aposento e dormiu como um anjo.

No dia seguinte quando Bianca acordou, seu noivo Gustavo já estava lá para saber notícias de sua amada. Quando a rainha desceu para tomar café, viu seu noivo, o rei, e começaram a se beijar. Logo depois de terminarem o café, rei Gustavo convidou rainha Bianca para um jantar em seu reino e ela aceitou.

Já na hora de ir ao jantar a rainha colocou um vestido bem bonito e saiu. Chegando lá, o rei não estava pronto, mas quando ele desceu a rainha ficou impressionada com a lindeza de seu noivo. Na hora do jantar eles estavam os dois sozinhos, mas não rolou nada.

Já no fim do jantar quando a rainha estava de saída, o rei não a deixou ir. Levou-a até seus aposentos e começaram a se beijar... Fizeram amor a noite inteira.

No dia seguinte logo depois do café a rainha Bianca foi embora e ficou o dia inteiro pensando na noite passada com seu amor.

Passou-se um mês e a rainha descobriu que estava grávida. Quando foi dar a notícia para o rei, eles decidiram marcar a data do casamento.

No dia do seu casamento a rainha estava com nove meses de gravidez e quase teve o bebê no casamento, segundo dia mais feliz de sua vida. Passaram-se uns quatro dias e, no dia 28/6/87, sua filha nasceu, em plena lua de mel. Ela se chamava Lara.

Quando a rainha e o rei chegaram no reino com sua filha Lara, todos ficaram surpresos com a princesa, porque ela era tão bonita que quando crescesse iria conseguir muito rápido vários pretendentes para se casar.

Passaram-se meses e o rei e a rainha estavam muito chateados, pois estavam quase separados, pois o sacerdote veio no meio dessa história de amor e falou que a rainha o tinha traído. Mas no dia do aniversário de um ano da princesa Lara eles se reconciliaram, pois o rei descobriu que era tudo mentira, e viveram felizes para sempre e sempre. 
Maiara: TEXTO 1 (Oficina 1)

Nome: O bunitão e gatão

Quem gosta: de todas as fadas

Quem não gosta: de magos

O que come: Passaros

Seu melhor amigo é um beija-flor

Ele é bonito é loiro uza roupa branca é casado tem filhos com a fada bela.

Gosta de gatos de pessoas de animais

Aparece sempre em uma luz branca é um troxa um babaca.

Não tenho mais nada para escrever.

Maiara: TEXTO 2 (inexistente: faltou à Oficina 2)

Maiara: TEXTO 3 (Oficina 3)

A Fada que amava

Era uma vez uma fada que se chamava estrela e ela adorava namorar elfos e quando ela olhou para Gabriel apaixonou-se profundamente por le, só que el tinha um problema, era umano como nós, e como estrela era uma fada e ela ainda era a fada madrinha dele! Era um pecado as fadas se apaixonarem - na verdade eu acho isso uma babaquice na verdade namorar uma fada é uma coisa as vezes normal, no mundo mágico é Claro, Mas voltando a estória...

Mas ela tinha uma escolha ou ela ficava no mundo mágico ou no mundo real. E Como ela amava muito Gabriel ela resolveu ir morar no mundo real com ele e eles viveram felises para senpre.

FIM

Maiara: TEXTO 4 (Oficina 4)

Hoje eu e Daniel decidimos ir ao zoologico fazer um passeio, lá nós vimos passáros e animais mas nós vimos um animal muito estranho eu acho que éra um monstro chamei Daniel e falei:

- Olhe aquele animal! Ele é tão estranho! - E Daniel falou:

- É verdade, vamos até lá ver como ele é! 
Eu e Daniel fomos até lá, e levamos um susto ele era um monstro mesmo, tinha somente um olho era verde com manchas amarelas eu percebi que ele estava chorando e também que a jaula estava aberta e perguntei a ele:

- Por que você está aqui? Conte sua estória para mim.

- Eu estava passeando por uma floresta quando eu era pequeno e me perdi mas fui encontrado pelo dono do zoológico e ele me criou aqui dentro dessa jaula e até hoje eu não vi mais a minha mãe.

- E seu pai você conhece?

- Não

O zoológico ia fechar, então chamei Daniel me despedi do monstro o fui embora.

Fim

\section{Maiara: TEXTO 5 (Oficina 5)}

\section{Cardápio 1: comidas nojentas}

\section{Café da manhã}

Gusp com ovo podre café com lesma esmagada gosma de molho branco com coco amaçado pedaço de americanos podres salxixa com azeite e xoio podre melequinha de nariz com braço de brazileiros cozidos

\section{Almoço}

- Gosma de lesma podre

- Suco de xixi com azeite

- Sobrimesa torta de bissoro esmagado e podre

Cardápio 2: comidas gostosas

- Frango assado

- Macarrão (qualquer tipo)

- Inhoque

- Peixe frito

- Anburgue

- Batata frita

- Camarão

- Rizoto

- Cozido de carne e batata 
- Lazanha

- Carne cozido

- Pizza (frango catupri)

- Bife com queijo

- Cachorro quente

Sobrimesa

- Muse de chocolate

- Pave de sonho de valsa

Maiara: TEXTO 6 (Oficinas 10 a 13)

\section{A princesa que era má}

Num castelo morava uma princesa que era muito boa, mas seu pai não a deixava namorar. Então ela foi se consultar com uma bruxa que não gostava dela, a bruxa acabou the jogando um feitiço que a deixou muito má.

A princesa (como era tão má) resolveu matar seu pai (o rei) para ficar com sua herança e poder casar-se com o príncepe Celso (que era sua paixão). Então foi até a cosinha pegou uma faca e foi até a sala do trono, logo depois se dirigiu ao trono de seu pai e quando ele menos esperava ela cortou a cabeça dele e acusou o bobo da corte pela morte de seu pai.

A princesa quando ela estava quase respondendo "sim" no seu casamento com o princepe Celso, o espirito de seu pai apareceu e a livrou da maudição que a bruxa tinha lhe jogado.

A princesa e o princepe viveram felizes para sempre.

Maiara: TEXTO 7 (Oficinas 16; 18 a 25)

Era uma vez uma rainha cujo seu marido havia morrido há 5 anos atrás.

E ela estava apaixonada pelo sacerdote do reino, mas ele era muito fiel a igreja, e quase nunca via alguém, somente nas missas que selebrava. A rainha era muito má e marcou um encontro com o sacerdote, então ela pensou... irei Chamalo hoje e vou me engravidar com ele. Mas tarde ela se arumou colocou um vestido bem bonito e ela muito bonito para seduzilo, ele foi e ela o jogou na cama e se engravidou a força. Quando ele descobriu largou a igreja e se casou com ela, como a rainha se satisfez ela virou uma 
pessoa boa e 9 meses depois eles tiveram um princepe muito bonito e viveram felizes para sempre.

Fim

Maiara,

Já comentamos um pouco $\sigma$ seu texto na última oficina e você disse que escreveria outra históría. Mas sería uma pena jogar fora isso que você já produziu, não? Talvez dê pra você inverter os papéis dos personagens $e$ acrescentar mais algum, preservando a trama. Por exemplo, você pode fazer com que $\sigma$ sacerdote seja $\sigma$ protagonista e a rainha a antagonista; ai você acrescenta um personagem fantástico como coadjuvante (afinal, é um conto de fadas). Você é quem sabe. Se quiser, pode escrever outra históría. Berjo! Andrea

\section{A rainha engenua}

Era uma vez uma rainha muito boa e linda, ela tiha o coração puro e todos os príncepes perto de seu reino amavam ela, todos os dias ela passeava pelo jardim com sua amiga a fada Andréa, ela era linda mas tinha um sacerdote que amava a rainha.

E tenta de tudo para que ela conversasce com ele e ela falou:

- Amanhã irei me confessar!

E ele falou é o grande dia irei engravidala amanhã mesmo.

No dia seguinte ela

A partir de então, passou a trabalhar sobre o texto digitado.

\section{A rainha ingênua}

Era uma vez uma rainha muito boa e linda, ela tinha o coração puro e todos os príncepes perto de seu reino amavam ela, todos os dias ela passeava pelo jardim com sua amiga a fada Andréa, ela era linda mas tinha um sacerdote que amava a rainha.

E tenta de tudo para que ela conversasce com ele e ela falou:

- Amanhã irei me confessar!

E ele falou é o grande dia irei engravidá-la amanhã mesmo.

No dia seguinte ela foi até a sacristia e o sacerdote veio até ela e rasgou suas roupas, quando ela estava nua ele tentou engravida-la mas a fada Andréa ouvio os gritos da rainha e correu até a sacristia e lansou um raio paralizante contra ele e a salvou das mãos do sacerdote depois a fada 
Andréa o transformou em pó, colocou em uma caixa. Elas tiveram que ir juntas jogar no mar para o feitiço dar serto, lá elas conheceram um rei, a rainha se apaixonou por ele.

Dois meses depois eles casaram e os três viveram felizes para sempre.

FIM

\author{
Maiara, \\ Faça uma revisão final do seu texto, prestando atençã o a o seguinte: \\ 1 - Algumas vírgulas podem (e devem) ser substituidas por pontos finais. \\ 2. As patavras em vermetho estão com algum probleminha de \\ ortografia e $\sigma$ que está em azul também precisa sofrer algum tipo de \\ modificação - procure descobrir o que deve ser alterado e corrigir. \\ Berjo da Andrea
}

Versão final:

\title{
A rainha ingênua
}

Era uma vez uma rainha muito boa e linda, ela tinha o coração puro e todos os príncipes perto de seu reino a amavam. Todos os dias ela passeava pelo jardim com sua amiga, a fada Andréa, que era linda.

Mas nesse reino tinha um sacerdote que amava a rainha. Ele tentava de tudo para que ela conversasse com ele e então ela falou:

- Amanhã irei me confessar!

E ele falou:

- É o grande dia, irei engravidá-la amanhã mesmo.

No dia seguinte ela foi até a sacristia. $O$ sacerdote veio até ela, rasgou suas roupas e, quando ela estava nua, tentou agarrá-la. A fada Andréa ouviu os gritos da rainha, correu até a sacristia, lançou um raio paralisante contra ele e a salvou das mãos do sacerdote. Depois a fada Andréa o transformou em pó e o colocou em uma caixa. Elas tiveram de ir juntas jogar no mar para o feitiço dar certo. Lá elas conheceram um rei e a rainha se apaixonou por ele, foi amor à primeira vista.

Logo depois de chegar em seu reino, ele deu uma grande festa para comemorar o encontro com seu grande amor.

Dois meses depois da festa eles casaram e os três viveram felizes para sempre. 
Pedro: TEXTO 1

Pior inimigo - mago

Melhor amigo - fada

Nome da fada - Brikle

Nome do eufo - Ramelot

Coisa que ele gosta - dar carinho a fada

Coisa que não gosta - brigar com o mago

Comida que ele mais gosta - espinafre refogado

Coisa que ele mais gosta - chu-chu com cuz-cuz

Pedro: TEXTO 2 inexistente: não compareceu à oficina 2

Pedro: TEXTO 3: em dupla com Celso (ver item anterior)

Pedro: TEXTO 4 (Oficina 4)

Um dia eu fui no zoologico com meus pais e um primo meu.

Lá eu vi varios bichos, so que o bicho mais imprecionante que eu vi não era bicho era um monstro esse monstro tinha quatro olhos quatro cabeças quatro bocas quatro nariz quatro braços quatro barrigas e em cada barriga tinha calombo que servia para ele andar ou melhor pular, é isso mesmo pular ele usava esse quatro calombos para pular, ele deitava de bruço ele começava a pular com esses calombos que na verdade eram quatro molinhas, e o nome dele era tudo quatro o por que voces já sabem.

\section{Pedro: TEXTO 5 (Oficina 5)}

\section{Cardápio 1: comidas nojentas}

Suco de merda velha, frango a milanesa misturado com bananas e tomates podres merda de boi assada enrolado com casca de banana e figado de gente morta e coração muido e merda fresca e tripas podres sem sal

Sobremesa

Bolinho de ranho 


\section{Cardápio 2: comidas gostosas}

Batata frita

Coxa de frango

Sorvete de napolitano

Pastel de carne

Cachorro quente

Espeto de carne

Pizza de muzzarela e frango com catupiri

\section{Pedro: TEXTO 6 (OFICINAS 10 a 13)}

\section{O fugitivo e o refem}

Numa noite escura e chuvosa um prisioneiro escapou da segurança máxima do FBI. E logo foi a procura de dinheiro. Ali perto ele avistou uma otima residência para ele assaltar, então quando ele achou melhor pulou a janela e foi direto para a cozinha onde estavam a mãe e os três filhos dela entre eles um menino.

O ladrão falou que so queria dinheiro mais nada, mas para a sua garantia ele levou o menino como refem.

No outro dia de manhã o ladrão pensou, pensou e ele resolveu que ia levar o menino de volta para a sua casa.

Chegando lá o ladrão pulou a janela como da primeira vez e foi ate a cozinha. Quando a mulher viu ele ela ficou muito assustada, mas o ladrão falou calma, calma, eu vim aqui para fazer o contrario do que eu fiz da primeira vez vim devolver seu dinheiro e seu filho.

Então a mulher deu um forte abraço no prisioneiro e o filho dele falou assim: eu acho que voces 2 formam um belo par e eles falaram assim também acho então foi assim que eles se casaram e foram viver no Caribe longe de tudo aquilo.

\section{Pedro: TEXTO 7 (Oficinas 16; 18 a 25)}

Era uma vez num reino muito distante, lá vivia uma bruxa muito poderosa chamada Bruxonilda.

Um belo dia iria ter uma apresentação de uma dancarina, e essa bruxa odiava dancarinas e resolveu transformar essa dancarina numa dancarina sem nenhuma habilidade.

No dia da apresentação um cavaleiro estava lá para assistir a apresentação. Quando a dancarina entrou no palco todo mundo aplaudiu. 
Pedro,

A idéia está bem legal! Procure explicar esse ódio que a bruxa tinha de dançarinas, para que o texto fique mais "amarradinho". Beijo! Andrea

Era uma vez num reino muito distante, lá vivia uma bruxa muito poderosa chamada Bruxonilda.

Um belo dia iria ter uma apresentação de uma dançarina, e essa bruxa odiava dançarinas por que ela tinha inveja e resolveu transformar essa dancarina numa dançarina sem nenhuma habilidade.

No dia da apresentação um cavaleiro estava lá para assistir a apresentação.

Todo mundo pensava que iria ser a maior apresentação já tida naquela epoca. Quanto mais a dancarina rodopiava ela ia ficando mais tonta que chegou a cair de cima do palco, ai foi só risada, todo mundo riu menos o cavaleiro que logo estava lá para socorrer a dancarina, ai quando eles se olharam de perto ficaram apaixonados um pelo outro.

A partir de então, passou a trabalhar sobre o texto digitado.

Era uma vez num reino muito distante, lá vivia uma bruxa muito poderosa chamada Bruxonilda.

Um belo dia iria ter uma apresentação de uma dançarina, e essa bruxa odiava dançarinas por que ela tinha inveja e resolveu transformar essa dancarina numa dançarina sem nenhuma habilidade.

No dia da apresentação um cavaleiro estava lá para assistir a peça.

Todo mundo pensava que iria ser a maior apresentação já tida naquela epoca. Quanto mais a dancarina rodopiava ela ia ficando mais tonta que chegou a cair de cima do palco, ai foi só risada, todo mundo riu menos o cavaleiro que logo estava lá para socorrer a dancarina, ai quando eles se olharam de perto ficaram apaixonados um pelo outro.

O cavaleiro levou a dancarina para a sua casa no alto de uma montanha que por coincidencia era do lado do reino da Bruxonilda.

A Bruxonilda ficou com muitissima inveja de novo porque ela viu os dois tomando um café de baixo de umas mangueiras de mais de cem anos. Então ela mandou uma carta para o cavaleiro, convidando-o para uma luta de poderes. O cavaleiro como não era nenhum bunda mole aceitou a 
luta mesmo não tendo nenhum poderes.

O cavaleiro como não tinha poderes nenhum ficou pensando no que iria fazer, de repente ele teve uma ideia muito boa. Ele lembrou de um ensinamento que o seu mestre lhe ensinou, que era o truque do espelho.

No dia da batalha, o cavaleiro com seu espelho escondido atrás de uma capa foi ate o lugar marcado. Quando ele chegou la ele teve uma surpresa a bruxa tinha sequestrado a dancarina, e ela so soltaria a bailarina se ele ganhasse a batalha. Na hora que a bruxa mandou seu primeiro e mais forte poder que ela tinha o cavaleiro colocou o espelho na frente do poder e quando o poder bateu no espelho voltou de volta para a má bruxa não tinha mais jeito ela morreu torradinha, mais o cavaleiro ainda tinha uma missão para fazer, que era libertar sua amada dancarina. Quando ele conseguiu liberta-la o feitiço que a bruxa tinha dado a ela não existia mais e assim ela voltou a ser a melhor dancarina da epoca.

Pedro,

Faça uma revisão funat do seu texto, prestando atenção ao seguinte:

1-Algumas vírgulas podem (e devem) ser substituidas por pontos finais. Há situações em que não há nem mesmo vírgula: procure focalizar este aspecto.

2. As palauras em vermetho estão com algum probleminha de ortografía e $\sigma$ que está em azul também precisa sofrer algum tipo de modificação - procure descobrir o que deve ser alterado e corrigir.

3. Grifei palauras e trechos em que há repetições: procure fazer substituições.

Beijoda Andrea

Versão final:

\section{A magia do espelho}

Era uma vez um reino muito distante, onde vivia uma bruxa muito poderosa chamada Bruxonilda.

Um belo dia iria ter uma apresentação de uma dançarina. Essa bruxa odiava dançarinas porque ela tinha inveja e resolveu transformá-la numa profissional sem nenhuma habilidade.

No dia da apresentação um cavaleiro estava lá para assistir à peça.

Todo mundo pensava que iria ser a maior apresentação já tida naquela época. Quanto mais a dançarina rodopiava, ela ia ficando mais tonta, até que chegou a cair de cima do palco. Aí foi só risada, todo mundo riu, menos o cavaleiro, que logo estava lá 
para socorrê-la. Quando eles se olharam de perto ficaram apaixonados um pelo outro.

Ele levou-a para a sua casa no alto de uma montanha, que por coincidência era do lado do reino da Bruxonilda.

A Bruxonilda ficou com muitíssima inveja de novo, porque ela viu os dois tomando um café debaixo de umas mangueiras de mais de cem anos. Então ela mandou uma carta para o cavaleiro, convidando-o para uma luta de poderes. Como ele não era nenhum bunda mole, aceitou a luta mesmo não tendo nenhum poder.

Ficou pensando então no que iria fazer; de repente ele teve uma idéia muito boa. Ele lembrou de um ensinamento de seu mestre, que era o truque do espelho.

No dia da batalha, o cavaleiro com seu espelho escondido atrás de uma capa foi até o lugar marcado. Quando chegou lá, ele teve uma surpresa: a bruxa tinha seqüestrado a dançarina e só a soltaria se ele ganhasse a batalha. Na hora que a bruxa mandou seu primeiro e mais forte feitiço, o cavaleiro colocou o espelho na frente e quando o feitiço bateu no espelho, voltou para a má bruxa. Não tinha mais jeito, ela morreu torradinha. Mas o cavaleiro ainda tinha uma missão para fazer, que era libertar sua amada dançarina. Quando ele conseguiu libertá-la o feitiço que a bruxa tinha dado a ela não existia mais e assim ela voltou a ser a melhor dançarina da época.

\section{Talita: TEXTO 1 (Oficina 1)}

Hoje na aula de produção de texto, discutimos sobre magos, fadas, elfos e bruxas. Discutimos as suas características.

Hoje também a professora pois um cd de som de tambor no começo da aula para acordar o corpo.

Pois também um cd com som de ondas para nós deitar-mos, e inventar uma história na imaginação.

Talita: TEXTO 2 (inexistente: faltou à Oficina 2)

Talita: TEXTO 3 (Oficina 3): produzido em dupla com Gabriela

Talita: TEXTO 4 (Oficina 4)

Um dia eu e minha classe fomos ao zoológico.

Da entrada vimos os tigres, eles eram enormes e muito bonitos.

Em seguida vimos os leões, alias tinham dois leões, era um leão e uma leoa, eles estavam comendo carne, o leão pegou uma ponta da carne e foi comendo, a leoa pegou a outra ponta e os dois foram comendo até chegarem pertinhos e de repente deram um beijinho.

Mais em frente eu vi uma coisa estranha, era um monstro. Ele tinha os pés iguais o do pato era verde e vermelho, tinha bolas amarelas pelo corpo, asas igual as de um morcego, um olho e uma orelha em cima da cabeça.

Foi ai que tentei conversar com ele, mas ai que descobri que ele se 
comunicava comas mãos.

Então perguntei de que país ele veio? Respondeu da China.

Depois de um tempo perguntei qual era o nome dele? Respondeu, claro com as mãos, Afranásio. embora.

Quando terminei de conversar com ele, fui ver os outros bichos e fui

\section{Talita: TEXTO 5 (Oficina 5)}

\section{Cardápio 1: comidas nojentas}
Almoço
Sopa de barata
Ranho quente com piolho
Salada de caramujo ao molho de pus
Sobremesa de chocolate feito com coco
Prato quente de orelha e nariz de rato
Petisco de lendias grudadas no cabelo

Cardápio 2: comidas gostosas

Frango a milanesa

Lasanha com bastante queijo

Moranga com catupiri e camarão

Risoto

Batata frita com sal

Churrasco

Musse

Pizza de catupiri

Cachorro quente

Talita: TEXTO 6 (Oficinas 10 a 13)

\section{O sumiço}

Era uma vez um príncipe chamado Jonas que morava com sua irmã Jacqueline (princesa) no castelo de Monterrei.

Um dia eles estavam passeando pela floresta quando sem mais nem 
menos apareceu um dragão que ninguém ainda tinha visto, rapitou a prinmcesa e começou a correr.

O principe desesperado começou a correr atrás dele, mas o dragão era muito veloz, e logo o perdeu de vista.

Desesperado o principe foi atrás de ajuda: chamou a polícia, amigos resgates, e muito mais.

No castelo do dragão, a princesa ficou trancada em um quarto bonito, mas com saldade do seu irmão chorava muito.

Sem mais nem menos a porta se abre, era o dragão:

- Oi princesa, não chore eu vim trazer um lanchinho para você!

- Dragão você é muito bom, eu pensava que você era rabugento, "sem coração", mais agora vejo que não!

- Mas senhor Dragão, por que o senho me rapitou?

- Eu te rapitei porque eu estava me sentindo muito sozinho.

- "Correto" - pensa ela

- Dragão, quantos km fica o meu castelo daqui?

- $500 \mathrm{~km} .$.

O príncipe tentando achar alguma pista do dragão de repente encontra 3 pegadas, então ele teve uma idéia

- As pegadas estão para o norte se eu continuar reto eu chego até o dragão...

... Passando 2 dias...

... - Que castelo enorme, deve ser o castelo do dragão, eu vou entrar e dar um tiro nele...

... De repente... buuuumm o príncipe não acerta, e por sorte a príncesa estava conversando com o dragão e

- Pare irmão, não o mate, ele é super bonzinho!...

- Irmão eu posso ficar com ele?

- Definitivamente não

- Tá bom vai - responde a príncesa.

Em Monterrei no castelo recebe-se a notícia de que um homem mata um dragão a príncesa fica muito triste e chora muito.

... Passando 4 meses...

A princesa hoje vive muito feliz com seu irmão, e nem lembra mais do...

Talita: TEXTO 7 (Oficinas 16; 18 a 25)

Era uma vez um rei que morava em um castelo muito bonito, ele era poderoso e rico. Seu amigo sacerdote, era muito bom e muito carinhoso, todos os animaisinhos que ele via na porta da sua igreja ele dava comida e banho. 
$\mathrm{Na}$ cidade havia um problema, pois um cavalheiro andava descontente com sua vida, emburrado, todos os objetos ou coisas que ele via na sua frente ele chutava.

O cavalheiro estava andando pela cidade, quando ele vê uns cachorros andando na sua frente, emburrado ele chuta e maltrata muito os caezinhos, no outro dia aconteceu a mesma coisa, e no outro e no outro e no outro, as pessoas da cidade já estavam ficando de saco cheio e decidem saber o que ele tinha, foram muitos dias de pesquisa, mas finalmente descobrem o problema: ele tinha sido enfeitiçado por uma bruxa, então eles decidem fazer uma coisa falar com o mago Leonardo para desenfeitica-lo.

Em um dia eles marcaram uma consulta com o mago para curalo.

No dia que eles marcaram a consulta foi a maior espectativa, e na hora que o cavalheiro saio de lá todos começaram a sorrir, pois ele tinha sido curado.

No outro dia o cavalheiro estava andando pela cidade quando passou um bando de cachorros na sua frente, todos se assustaram pois

Talita,

Procure explicar por que orapaz foi enfeitiçado. A históría está legal, só está faltando essa "amarração". Beijo! Andrea

Era uma vez um rei que morava em um castelo muito bonito, ele era poderoso e rico. Seu amigo sacerdote, era muito bom e muito carinhoso, todos os animaisinhos que ele via na porta da sua igreja ele dava comida e banho.

$\mathrm{Na}$ cidade havia um problema, pois um cavalheiro andava descontente com sua vida, emburrado, todos os objetos ou coisas que ele via na sua frente ele chutava.

O cavalheiro estava andando pela cidade, quando ele vê uns cachorros andando na sua frente, emburrado ele chuta e maltrata muito os caezinhos, no outro dia aconteceu a mesma coisa, e no outro e no outro e no outro, as pessoas da cidade já estavam ficando de saco cheio e decidem saber o que ele tinha, foram muitos dias de pesquisa, mas finalmente descobrem o problema: ele tinha sido enfeitiçado por uma bruxa. A bruxa enfeitiçou o cavalheiro, pois houve uma festa no castelo dela, e o cavalheiro tinha apresentado uma mulher para o marido dela, e ele acabou se apaixonando por ela, e até casou com ela escondido e fugiram do país, e a bruxa começou a desconfiar e com muita raiva enfeitiçou o cavalheiro. Então eles decidem fazer uma coisa falar com o mago Leonardo para desenfeitica-lo.

Em um dia eles marcaram uma consulta com o mago para curalo.

No dia que eles marcaram a consulta foi a maior espectativa, e na hora que o cavalheiro saio de lá todos começaram a sorrir, pois ele tinha sido curado. 
No outro dia o cavalheiro estava andando pela cidade quando passou um bando de cachorros na sua frente, todos se assustaram pois ele estava começando a fazer carinho neles, o povo da cidade ficou super feliz pois ele tinha sido curado.

A partir de então, passou a trabalhar sobre o texto digitado.

\section{O mistério descoberto}

Era uma vez um rei que morava em um castelo muito bonito, ele era poderoso e rico. Seu amigo sacerdote, era muito bom e muito carinhoso, ele tinha muitos animais, todos os cães que ele achava na rua ele acolhia.

$\mathrm{Na}$ cidade havia um problema, pois um cavalheiro andava descontente com sua vida, emburrado, todos os objetos ou coisas que ele via na sua frente ele chutava.

O cavalheiro estava andando pela cidade, quando ele viu uns cachorros andando na sua frente, emburrado ele chuta e maltrata muito os caezinhos, no outro dia aconteceu a mesma coisa, e no outro e no outro e no outro, os cachorros que o cavalheiro chutava eram do sacerdote, este

foi reclamar com o rei, que pediu auxilio ao mago Leonardo, seu conselheiro.

O rei tinha marcado uma consulta com o mago para curalo.

No dia que ele tinha marcado a consulta foi a maior concentração e finalmente descobriu o problema: ele tinha sido enfeitiçado por uma bruxa. A bruxa enfeitiçou-o, pois à muito tempo atrás ela tinha dado uma festa em seu castelo; o cavalheiro tinha apresentado uma mulher para o marido dela, e ele acabou se apaixonando por ela. Até se casaram escondido e fugiram do país. E a bruxa começou a desconfiar e com muita raiva enfeitiçou o cavalheiro.

No dia seguinte depois da consulta o cavalheiro estava andando pela cidade quando viu os cachorros do sacerdote, todos se assustaram pois ele 
estava começando a fazer carinho neles, o povo da cidade ficou super feliz pois ele tinha sido curado.

Talita,

Faça uma revisã $\sigma$ final do seu texto, prestando atenção a o seguinte:

1- Algumas vírgulas podem (e devem) ser substituidas por pontos finais.

2. As palauras em vermetho estão com algum probleminha de ortografia e o que está em azul também precisa sofrer algum tipo de modificação - procure descobrir o que deve ser alterado e corrigir.

Beýo da Andrea

Versão final:

\section{O mistério descoberto}

Era uma vez um rei que morava em um castelo muito bonito, ele era poderoso e rico. Seu amigo sacerdote era muito bom e muito carinhoso, ele tinha muitos animais, todos os cães que ele achava na rua ele acolhia.

$\mathrm{Na}$ cidade havia um problema, pois um cavalheiro andava descontente com sua vida, emburrado, todos os objetos ou coisas que ele via na sua frente ele chutava.

O cavalheiro estava andando pela cidade, quando viu uns cachorros andando na sua frente. Emburrado, chutou e maltratou muito os cãezinhos. No outro dia aconteceu a mesma coisa, e no outro e no outro e no outro.

Os cachorros que o cavalheiro chutava eram do sacerdote, este foi reclamar com o rei, que pediu auxílio ao mago Leonardo, seu conselheiro. O rei marcou uma consulta com o mago para curá-lo.

No dia em que ele tinha marcado a consulta foi a maior concentração e o mago finalmente descobriu o problema: ele tinha sido enfeitiçado por uma bruxa. A bruxa enfeitiçou-o, pois há muito tempo atrás ela tinha dado uma festa em seu castelo; o cavalheiro tinha apresentado uma mulher para o marido dela e eles acabaram se apaixonando. Até se casaram escondido e fugiram do país. A bruxa começou a desconfiar e com muita raiva enfeitiçou o cavalheiro.

No dia seguinte, depois da consulta, o cavalheiro estava andando pela cidade quando viu os cachorros do sacerdote; todos se assustaram pois ele estava começando a fazer carinho neles. O povo da cidade ficou super feliz pois ele tinha sido curado. 
V.4.c.iv) As imagens produzidas

Para ver as imagens, baixe o arquivo "No universo das historias - Imagens.pdf" 
V.4.c.v)Apreciação das oficinas do ponto de vista dos participantes, de suas mães e de suas professoras ${ }^{1}$

\section{Entrevistas e questionário}

No final de 97, uma semana depois da última oficina, fiz entrevistas com as mães e com as professoras das crianças. Falei com as mães por telefone e expliquei em linhas gerais sobre o que gostaria de conversar. Com as professoras não havia conseguido marcar previamente: fui até elas na hora mesmo e requisitei sua presença, ao que elas atenderam. Era dia de reunião de pais - a última do ano - e ajustei-me à disponibilidade das entrevistadas: uma das mães só podia conversar comigo antes da reunião. Depois as outras foram chegando, de forma que as entrevistas se deram em cinco etapas: a primeira com somente uma mãe, a segunda com três, a terceira com duas; a quarta e a quinta, cada um com uma professora.

Fiz uma pergunta inicial, a partir da qual se foram tecendo comentários, diante dos quais muitas vezes eu fazia outras perguntas. A pergunta inicial foi:

Como vocês perceberam/sentiram a participação de seu filho/sua filha nas oficinas? Pelo seu acompanhamento dele/dela, através das lições de casa, conversas etc, você sente que ele/ela sofreu alguma influência desse trabalho que nós fizemos aqui? Houve mudanças?

Quando ouvia uma resposta afirmativa, perguntava:

E por que você acha que essas mudanças têm a ver com a participação nas oficinas?

As mães revelaram-se muito disponíveis e envolvidas na conversa comigo, de forma geral.

\footnotetext{
${ }^{1}$ Trechos das entrevistas e parte das respostas ao questionário encontram-se nos anexos 14 a 17 . Apresento somente as respostas significativas para a análise, já que muitas das perguntas referem-se a uma espécie de sondagem de interesses, que não têm muito valor para análise, uma vez que não tive idéia de fazer o mesmo, dessa forma sistematizada, antes do início das oficinas (apenas fiz algumas perguntas a respeito, oralmente, no primeiro encontro, ainda no "estudo prévio"). A pergunta 15 foi desconsiderada porque percebi que o fato de ter sido feita muito tempo depois que as atividades haviam acontecido havia feito com que as respostas não pudessem ser consideradas como significativas - há vários casos de crianças que deram notas para atividades das quais sequer participaram, pois faltaram à oficina correspondente. Os dados, nos anexos, estão também divididos conforme os recortes temáticos "interesse", "desempenho na escrita" e, no caso das entrevistas, há também a transcrição do trecho em que P1 fala sobre "cooperação".
} 
A professora de Gabriela e Graziela (P2) mostrou-se um tanto hermética quando a entrevistei pela primeira vez: "a única coisa que podia dizer" era que as crianças gostavam muito das oficinas, porque comentavam; nada mais que isso, pois já eram alunas muito boas, sempre tinham sido, e ela não notava nenhuma mudança. Acho que fiquei um tanto paralisada com suas respostas monossilábicas a minhas perguntas e não consegui ir adiante com a conversa. No entanto, a seguir entrevistei a professora de Celso, Maiara, Pedro e Talita (P1), que se mostrou mais aberta, e a conversa com ela tomou um rumo tal que me forneceu algumas idéias para voltar a questionar P2 - o que fiz no início de 98.

Em duas oficinas do primeiro semestre de 98, pediu-se às crianças que respondessem a um questionário de avaliação pessoal. As respostas que deram a algumas questões indicaram que sua formulação não estava clara; tais questões foram então reformuladas e pediu-se que as respondessem novamente.

Foram consideradas para a análise somente as respostas que estão em anexo, conforme já foi explicado em nota de rodapé.

Análise por recortes temáticos: interesse e desempenho na escrita

No que se refere ao interesse das crianças pelas atividades realizadas nas oficinas, por leitura e escrita em geral e por continuar freqüentando Oficinas de Redação e Criatividade, conforme os dados mencionados (que corroboram o que observei, de forma geral) podem-se fazer as seguintes afirmações:

Primeira: As crianças demonstraram interesse pela maior parte das atividades realizadas nas oficinas. ${ }^{1}$

Segunda: As oficinas ofereceram um estímulo para escrever, tiveram influência sobre as crianças em termos de interesse ou desbloqueio em relação a atividades de escrita e leitura em geral.

\footnotetext{
${ }^{1}$ À pergunta 20 do questionário, duas crianças responderam que estavam "enjoadas" do trabalho, atribuindo seu enfado ao fato de estarem há muito tempo freqüentando as oficinas. Acho que não foi bem isso e sim o tipo de atividade que estava sendo proposta nas oficinas imediatamente anteriores àquela em que responderam ao questionário - a respeito das quais já comentei ao relatar as oficinas. Conforme já anunciei, voltarei a esse assunto no último capítulo.
} 


\section{Terceira: Demonstrou-se interesse em dar continuidade às oficinas.}

Quanto ao desempenho das crianças na escrita, conforme os dados de que trata este item (que corroboram o que se pode observar nos textos produzidos), pode-se fazer a seguinte afirmação:

O trabalho realizado exerceu influência sobre a escrita das crianças. Houve mudanças na forma de escrever e/ou no conteúdo dos textos que podem ser atribuídas à sua freqüência às oficinas.

Um aceno à cooperação: outro aspecto que veio à tona numa entrevista

P1 comentou na entrevista que notou uma mudança interessante no comportamento de Talita, no que se refere a sua disponibilidade para ajudar colegas quando trabalhava em duplas, na sala de aula. Isto acena - ainda que "de longe", pois foi observado em apenas uma aluna - para a possibilidade de que um trabalho como o realizado nestas oficinas tenha repercussões do ponto de vista da cooperação no trabalho em equipes em outros contextos (além do das próprias oficinas). Embora essa "generalização da experiência" tenha vindo à tona somente em relação a um caso, o tema do trabalho em equipe permeou todo o processo nas oficinas, em que ficou clara sua importância e eficiência para uma aprendizagem ativa e significativa. 


\section{APÊNDICE DO ITEM V.4}

\section{SOBRE CONTOS: TERMILOGIA E CONSIDERAÇÕES TEÓRICAS ${ }^{1}$}

Os contos populares, maravilhosos, de magia, de fadas

Contos populares são histórias anônimas advindas da tradição oral, ou seja, originalmente transmitidas de geração a geração somente pela linguagem oral. Muitas delas foram registradas em algum momento por pessoas como Giambattista Basile, Charles Perrault (cujas narrativas eram marcadas por uma "moral", que ele sempre acrescentava ao final dos contos), os irmãos Jakob e Wilhelm Grimm, Italo Calvino, Luís da Câmara Cascudo etc. Hans Christian Andersen $^{2}$ foi o primeiro autor que, depois de já ter feito um trabalho semelhante de compilação de contos populares, passou a escrever histórias que ele mesmo inventava, como é o caso de O Patinho Feio (ANEXO 7). É considerado, por isso, o primeiro escritor de literatura infantil. ${ }^{3}$

A denominação conto popular não deixa muita margem a dúvidas. $O$ mesmo não acontece, no entanto, em relação a algumas classificações que podem ser feitas dentro deste universo. O que se pretende é deixar claro qual é o tipo de material cuja estrutura serviu de base para o trabalho realizado no presente estudo. Ou seja, especificar "que nome está sendo dado a quais bois". Longe de querer resolver as divergências, portanto, procurarei inicialmente expor como, dentro da própria obra de Propp, o emprego dos termos conto maravilhoso e conto de magia nem sempre se diferencia claramente. No próximo item, tratarei de deixar claros os nomes utilizados nesta dissertação e os respectivos significados.

Vladimir Propp, em Morfologia do conto maravilhoso ${ }^{4}$ realizou um

\footnotetext{
${ }^{1}$ Peço a paciência do leitor com as citações às vezes um tanto longas presentes neste apêndice... Fiz esta opção por tratar-se de uma espécie de diálogo com um texto em que a terminologia referente aos contos deixa muita margem a dúvidas.

${ }^{2}$ Sobre Basile, Perrault, os irmãos Grimm e Andersen, consultar o capítulo "Aspectos históricos dos contos de fada" em Contos para escrever-se: alfabetização por meio dos contos de fadas (GOING, Luana C.)

${ }^{3}$ Tais informações constam do artigo de Regina Zilberman publicado no final do livro $\underline{\mathrm{O} \text { Patinho Feio }}$ (ANDERSEN, Hans Christian).

${ }^{4}$ Todas as citações do autor nesta dissertação referem-se a esta obra.
} 
estudo sistemático de um grande número de contos populares russos, em busca de regularidades que lhe permitissem estabelecer - como o título do livro já diz uma morfologia:

No âmbito do conto popular, folclórico ${ }^{1}$, o estudo das formas e o estabelecimento das leis que regem sua disposição é possível com a mesma precisão da morfologia das formações orgânicas.

Se não se pode aplicar esta afirmação ao conto maravilhoso em geral, em toda a amplitude do vocábulo, pode-se aplicá-la certamente aos denominados contos de magia "no sentido exato desta palavra". O presente trabalho está dedicado apenas a este último tipo de conto. (PROPP, Vladimir - p. 11)

O autor deixa claro, assim, que há uma diferença entre contos maravilhosos e de magia. Isto fica ainda mais evidente no artigo "Estudo estrutural do conto de magia" em que responde às críticas feitas a sua obra por Lévi-Strauss (publicado como apêndice no livro Morfologia do conto maravilhoso):

(...) se o tradutor [tradução inglesa] prestou um péssimo serviço ao leitor deixando de lado as epígrafes de Goethe, outra violência contra o autor foi cometida não pelo tradutor, mas pelo editor russo, que publicou o livro: seu título foi mudado. Chamava-se Morfologia do Conto de Magia. Para conferir maior interesse ao livro, o redator suprimiu o termo "de magia" e com isso levou os leitores (e com eles o professor Lévi-Strauss) ao equívoco de acreditar que no livro se pesquisassem as leis gerais do conto maravilhoso como gênero. Um livro com este título poderia estar situado no mesmo nível de estudos do tipo "Morfologia da conspiração", "Morfologia da fábula", "Morfologia da comédia" e assim por diante. Mas o autor não se propusera a estudar todos os tipos deste gênero variado e complexo que é o conto maravilhoso como tal, e examinava somente um tipo, assim mesmo, apenas os populares. (...) Assim, por exemplo, os contos cumulativos estão construídos sobre princípios totalmente diferentes daqueles dos contos de magia. Estes são denominados, no estudo do folclore inglês, Formula Tales, e os tipos de fórmulas nos quais se baseiam podem ser reconhecidos e determinados, mas seus esquemas não correspondem, em absoluto, ao dos contos de magia. (Idem - p. 210)

No entanto, muitas vezes Propp usa o termo conto maravilhoso para designar os contos cujos elementos está estudando, cuja estrutura está nos revelando. Isto acontece, por exemplo, no início do capítulo em que enumera "(...) as funções dos personagens na ordem ditada pelos próprios contos maravilhosos." [grifo meu] (Idem - p. 31)

Ou no artigo citado:

\footnotetext{
${ }^{1}$ Grifo meu para chamar a atenção sobre a declaração do autor de que seu estudo se refere ao universo do conto popular.
} 
Estudando o conto maravilhoso, podemos notar que algumas funções se agrupam facilmente em pares. (...) Nos contos maravilhosos encontramos o herói verdadeiro e o falso-herói: o verdadeiro executa a tarefa e é recompensado, o falso não consegue fazê-lo e é castigado. Assim, o rapto da princesa (dano inicial, primeiro elemento da intriga) encontra-se no início do conto, enquanto que o seu regresso (desfecho) tem lugar somente na conclusão. (Idem - p. 217)

llumina-nos um lampejo de esperança de pôr um fim definitivo à dúvida em relação aos dois termos utilizados por Propp quando ele começa a frase:

Por conto de magia entenderemos...

Mas logo vem o balde de água fria:

...os que estão classificados no índice de Aarne e Thompson entre os números 300 e 749. (Idem - p. 25)

: $\ldots$

Do que Propp escreveu sobre contos maravilhosos e contos de magia, podese concluir que os primeiros se referem a um universo ao qual os últimos pertencem. Pode-se depreender também que o conto maravilhoso pertence a um grupo diferente do da fábula. Propp refere-se à presença, em muitos contos, de "objetos mágicos", mas há contos (que possuem a estrutura por ele atribuída aos contos de magia) nos quais não aparecem tais objetos. Assim, não fica muito claro exatamente por que Propp não optou por utilizar sempre o termo contos de magia e referiu-se muitas vezes aos contos pertencentes ao material por ele analisado como maravilhosos.

Para complicar ainda mais a situação, perguntemos: e os contos de fadas, seriam o quê?

Segundo a definição de Irene Machado em Literatura e Redação,

Todo conto de fadas apresenta histórias de príncipes e princesas - os heróis - que vivem problemas terríveis causados por seres malévolos - as bruxas -, mas, felizmente, contam com os seres mágicos: fadas, magos, anões. Por isso os conflitos são provocados por uma intenção maldosa contra uma pessoa do bem e só se resolvem pelo encantamento. $O$ herói sofre a perseguição do mal - a bruxa -, o que faz aumentar o conflito até o final, quando a virtude triunfa e o ser malévolo é impiedosamente castigado. Assim, tudo termina com final feliz. (MACHADO, Irene. Literatura e Redação. p. 45) 
O clássico conto "Chapeuzinho Vermelho" (ANEXO 18) não seria, segundo esta definição, um conto de fadas, pois apesar da presença de acontecimentos sobrenaturais (como aliás é característico dos contos maravilhosos em geral), o encantamento não é provocado pela ação de um ser sobrenatural. As duas versões mais conhecidas deste conto terminam de modo diferente: a dos Grimm tem um final feliz e seu enredo se constrói segundo a estrutura do que Propp denomina conto de magia; já não se pode dizer o mesmo da versão de Perrault (ANEXO 19), na qual a menina e sua avó não têm a mesma sorte: ambas são devoradas pelo lobo, como acontece na outra versão; mas não aparece caçador algum para salvar-Ihes a pele.

Propp alerta o leitor ainda para o seguinte fato:

\footnotetext{
Alguns contos não de magia, bastante raros, podem ser construídos segundo o esquema citado. Um número considerável de lendas, fábulas de animais e algumas novelas isoladas possuem a mesma construção. Portanto, a expressão de magia deveria ser substituída por outro termo. Tal termo é muito difícil de ser encontrado e, por isso, conservaremos provisoriamente a antiga denominação. (PROPP, Vladimir - p. 92)
}

De qualquer forma, o mais importante aqui não é a terminologia referente aos contos - mesmo porque, quanto a isso há muitas controvérsias e sim a estrutura de conto utilizada neste estudo, bem como o universo que este tipo de conto abrange. E não há dúvida quanto ao fato de que os contos populares denominados de magia por Propp possuem a estrutura que ele evidenciou, como veremos adiante.

Os tipos de personagens

Este item tratará da forma escolhida para designar os diferentes tipos de personagens que aparecem nas histórias, conforme o papel que desempenham. Esta não é, evidentemente, a única forma que existe. Propp, por exemplo denomina heróis os personagens aos quais referir-me-ei como protagonistas. Fiz esta escolha apenas por considerar este termo mais neutro em relação ao primeiro, o qual pode suscitar idéias que não correspondem à totalidade dos protagonistas. Idéias como as presentes em algumas das definições que se lêem 
no Dicionário Aurélio Eletrônico (BARROSO, Márcio E. G.): "homem extraordinário por seus feitos guerreiros, seu valor ou sua magnanimidade"; "semideus" (mitologia). Sendo que ao protagonista nem sempre se podem atribuir tais características.

Propp identificou nos contos populares de magia sete tipos de personagens (antagonista ou malfeitor; doador ou provedor; auxiliar; princesa (personagem procurado) e seu pai; mandante; herói; falso herói) entre os quais se distribuem as funções - funções estas que "se agrupam logicamente segundo determinadas esferas. (...) São as esferas da ação." (PROPP, Idem. p. 73). Um personagem pode corresponder a somente uma ou a mais de uma esfera de ação; pode acontecer também de uma única esfera de ação se dividir entre vários personagens. Mas para este estudo adotou-se uma classificação mais simples, segundo a qual os personagens são de três tipos: protagonistas, antagonistas e coadjuvantes. O protagonista é aquele em torno do qual a trama se desenvolve. É a vida dele que está em foco, ele é que realiza ou detona as ações que culminarão numa transformação - ou é em função dele, com referência nele, que tais ações se realizam. E esta transformação em geral diz respeito diretamente a sua pessoa. O personagem antagonista é aquele que tenta atrapalhar a vida do protagonista. Os coadjuvantes são os outros personagens, que estão junto ao protagonista ou ao antagonista.

Nos contos de magia o protagonista é em geral um príncipe ou princesa, um andarilho ou andarilha, camponês ou camponesa etc, que conta muitas vezes com a ajuda de personagens coadjuvantes "do bem": as fadas, elfos, magos, magas etc. Outros coadjuvantes são os parentes, conhecidos e auxiliares do protagonista ou do antagonista. $O$ antagonista é um ser (nem sempre fantástico) "do mal": madrasta, bruxa, dragão, gigante, o diabo etc.

É em função das ações dos personagens que se desenvolve a narrativa. $O$ protagonista defende os fracos e pode ter um companheiro; o antagonista é sempre ganancioso, amoral e egoísta, cercado de seres malévolos, muitas vezes meio idiotas (como as hienas no filme dos estúdios Disney "O rei leão", por exemplo).

Freqüentemente, os personagens dos contos populares não têm nome 
próprio. Alguns autores, como Nelly Novaes Coelho, os denominam "personagens-tipo". Conforme a autora, "são personagens estereotipadas"1. Ou seja, suas ações sempre se repetem (Propp nos mostrou como há um número limitado de funções). Não constituem uma personalidade única, com suas peculiaridades - ao contrário, suas ações são perfeitamente previsíveis.

Às vezes o protagonista está "subdividido" em mais de um personagem, muitas vezes um feminino e outro masculino, como é o caso de "Joãozinho e Mariazinha" (ANEXO 20). Isto pode ser visto como uma forma de representar diversos aspectos de uma personalidade em desenvolvimento, como afirma Bruno Bettelheim, ao comentar o conto "Irmão e Irmã" - "Maninho e Maninha" (ANEXO 21) na edição brasileira que consta da bibliografia desta dissertação. ${ }^{2}$

Em "O quadro de pano" (ANEXO 22): também há um desdobramento desse tipo; no caso, trata-se de uma mãe e seu filho mais novo, que se dedica a resgatar o quadro que ela tecera e que fora levado pelo vento.

\section{Estrutura e transformações nos contos populares de magia}

(...) Se o característico das totalidades estruturadas é depender de suas leis de composição, elas são, portanto, estruturantes por natureza e essa constante dualidade ou, mais precisamente, bipolaridade de propriedades de serem sempre e simultaneamente estruturantes e estruturadas, é que explica, em primeiro lugar, o sucesso dessa noção que (...) assegura sua inteligibilidade através de seu próprio exercício. Ora, uma atividade estruturante não pode consistir senão em um sistema de transformações. (PIAGET, Jean. O estruturalismo, p. 12)

Propp conseguiu identificar, nos cem contos que analisou, trinta e uma funções ${ }^{3}$ possíveis - e apenas trinta e uma. Não que todas elas apareçam em cada conto, mas todo conto maravilhoso de magia tem algumas delas, numa determinada ordem. São funções tais como: "um dos membros da família sai de

\footnotetext{
${ }^{1}$ COELHO, Nelly N. A Literatura Infantil. p. 52

2 "Nesta estória dos Irmãos Grimm, como em muitos outros contos que retratam as aventuras de dois irmãos, os protagonistas representam as naturezas díspares do id, ego e superego; e a mensagem principal é que eles devem ser integrados para a felicidade humana." (BETTELHEIM, Bruno. p. 99)

${ }^{3}$ Sobre o termo "função", vale citar Propp: "Segundo a minha definição do termo para a pesquisa em questão, por função se entende a atuação do personagem, determinada do ponto de vista de seu significado para o desenvolvimento da ação. (...) A palavra 'função' é, portanto, um termo convencional que em nosso trabalho deve ser compreendido apenas neste sentido, excluindo qualquer outro." (Morfologia do conto maravilhoso, p. 215)
} 
casa"; "impõe-se ao herói uma proibição"; "a proibição é transgredida” etc.

O que muda são os nomes (e, com eles, os atributos) dos personagens; o que não muda são suas ações, ou funções. Daí a conclusão de que o conto maravilhoso atribui freqüentemente ações iguais a personagens diferentes. Isto nos permite estudar os contos a partir das funções dos personagens. (Idem - p. 25)

O conto maravilhoso, habitualmente, começa com certa situação inicial. Enumeram-se os membros de uma família, ou o futuro herói (...) é apresentado simplesmente pela menção de seu nome ou indicação de sua situação. Embora esta situação não constitua uma função, nem por isso deixa de ser um elemento morfológico importante. (Idem - p. 31)

Do ponto de vista morfológico podemos chamar de conto de magia todo desenvolvimento narrativo que, partindo de um dano (...) ou uma carência (...) e passando por funções intermediárias, termina com o casamento (...) ou outras funções utilizadas como desenlace. A função final pode ser a recompensa (...) a obtenção do objeto procurado ou, de modo geral, a reparação do dano (...), o salvamento da perseguição. A este desenvolvimento damos o nome de SEQÜÊNCIA. A cada novo dano ou prejuízo, a cada nova carência, origina-se uma nova seqüência. Um conto pode compreender várias seqüências (...) (Idem - p. 85)

Isto é, os contos populares de magia guardam algumas características comuns, uma estrutura básica que é invariante. Para este estudo, utilizou-se a essência desta estrutura, seus elementos fundamentais - ou seja, optou-se trabalhar junto às crianças com uma fórmula de conto simplificada, sem entrar em detalhes quanto às funções dos personagens. Esta fórmula simplificada resulta de uma apreensão pessoal do que propõe Propp (como será exposto mais detalhadamente no próximo item). Ou seja: nesses contos, sempre se apresenta um problema (conflito), em torno do qual se sucedem alguns acontecimentos que engendrarão seu desenlace, sendo que, do começo para o final do conto, dá-se um processo de transformação. É nessa estrutura básica dos contos de magia que recai a ênfase do trabalho realizado a partir do segundo semestre de 1997 (depois de se terem explorado elementos pertencentes ao universo do conto de magia (entre outros) a partir do elemento "personagem"), dando-se especial atenção para o fato de que algo se transforma do começo para o final do conto, sendo isso o que possibilita 0 desenlace - nos contos de magia, sempre um final feliz.

Pode-se ver a estrutura dos contos populares de magia, portanto, como um bom modelo de estrutura, já que todo conto contém em si, necessariamente, uma - no mínimo uma - transformação. A estrutura dos contos é uma forma, à qual 
podem corresponder diferentes conteúdos. ${ }^{1}$

Uma vez esclarecido o aspecto estrutural dos contos populares de magia, volto ainda uma vez à questão da terminologia relativa aos tipos de contos, no intento de que não reste dúvida quanto à minha apreensão do que seja um conto popular de magia e um conto de fadas - e conseqüentemente o sentido atribuído a tais expressões nesta dissertação.

Os contos (populares) de magia são contos maravilhosos que possuem a estrutura evidenciada por Propp (conforme vimos neste item), nos quais podem aparecer objetos mágicos, mas não necessariamente. A partir da apresentação da situação inicial, coloca-se um problema ou conflito (às vezes logo no início, outras vezes mais adiante). É basicamente em torno deste problema que os personagens passam a desempenhar determinadas funções ou ações, até o desenlace (final feliz), em que o protagonista sempre tem sucesso (em geral não facilmente). $O$ antagonista muitas vezes é punido. No mundo do conto de magia, qualquer ser pode existir, qualquer coisa pode acontecer.

Parece coerente dizer, então (como propõe Irene Machado no texto citado), que o conto (popular) de fadas é um tipo específico de conto de magia em que aparecem fadas e/ou outros seres fantásticos (elfos, anões, duendes, uma velha que dá ao protagonista um objeto mágico ou the ensina como obtê-lo etc) como personagens coadjuvantes ou antagonistas (bruxas, trolls - monstros da tradição norueguesa -, dragões maus etc). Pode haver objetos mágicos, mas nem sempre isto ocorre.

\footnotetext{
${ }^{1}$ Para falar de forma e conteúdo, recorro a Lino de Macedo: "Hefesto, em sua trajetória para conquistar Afrodite, pensou na rede como correspondente de duas necessidades: primeiro, provar suas freqüentes traições (no ponto de vista de Hefesto), e segundo, retê-la - com sua infinita beleza e com seu eterno amor só para ele. O ponto de chegada, já sabemos, foi que Hefesto, não logrando reter Afrodite, apreendeu dela a beleza e o amor (forma sempre buscada de relacionamento com um outro ou consigo mesmo) como conteúdos, então necessários aos seus esquemas de ações. Ele, que se tornou o artista preferido dos deuses e dos homens. Em síntese, para construir algo como uma forma é necessário que os conteúdos da ação diferenciem-se, multipliquem-se criativamente, tornando assim possível sua assimilação como algo novo. Para tanto, as transformações das ações estão subordinadas às suas correspondências com o objeto, cuja forma trata-se de fixar como imagem, gesto, utensílio, texto, obra de arte, etc. Para construir algo como um conteúdo, a criança, por suas ações, deve retirar das diversas formas que o expressam, aquilo que lhes é comum, que lhes dá coerência (lógica ou estética), que se conserva de uma forma para outra." (MACEDO, Lino de. Ensaios Construtivistas, p. 9)
} 
O antagonismo conflito-desenlace é tratado como uma pulsação, já que a narrativa dos contos populares de magia apresenta sempre:

1- Uma situação inicial, na qual se apresentam os personagens e se fornecem alguns dados sobre como vivem e o que está se passando com eles.

2- Um problema (conflito). Em torno dele se desenrola um processo ao longo do qual se engendra uma transformação.

3- Uma resolução ou desenlace. A transformação se efetiva.

Ou seja, uma situação de tensão/conflito é superada (relaxamento/resolução) graças a um processo que culmina numa transformação, muitas vezes acompanhada de uma revelação. Como em "A Gata Borralheira" (ANEXO 23): quem é aquela dançarina deslumbrante por quem o príncipe se apaixona? O sapatinho a revela e a situação toda se reverte: ela deixa de sofrer as penúrias a que era submetida pela madrasta e suas filhas e alcança o que elas mais desejavam - torna-se princesa. Tudo isso graças ao fato de nunca ter perdido a fé e ter seguido à risca o conselho que a mãe lhe dera antes de morrer. ${ }^{1}$

No senso comum, um conflito ${ }^{2}$ se dá quando duas ou mais tendências divergentes se apresentam, gerando discussão, embate, confronto ou, se as tendências em jogo têm igual intensidade, pode-se ter uma situação de paralisia ou "congelamento". Nos contos, conflito é o nó da narrativa, que precisa ser desatado; é o problema a ser resolvido. Em contos com mais de uma seqüência, depois de resolvido um problema, surge outro e lá vai o protagonista

\footnotetext{
1 "Filha querida, sê devota e boa; então o bom Deus sempre te valerá, e eu olharei por ti lá do céu, e estarei sempre perto de ti." (GRIMM, Jakob e Wilhelm. Os contos de Grimm, p. 13)

${ }^{2}$ Verbete: conflito

[Do lat. conflictu.]

S. m.

1. Embate dos que lutam.

2. Discussão acompanhada de injúrias e ameaças; desavença.

3. Guerra (1).

4. Luta, combate.

5. Colisão, choque: As opiniões dos dois entram sempre em conflito.

6. Teat. O elemento básico determinante da ação dramática, a qual se desenvolve em função da oposição e luta entre diferentes forças; conflito dramático.
} 
novamente lidar com ele, realizando muitas vezes, então, funções diferentes daquelas presentes na primeira seqüência. $O$ protagonista está sempre relacionado às ações que resultam na resolução do problema, mesmo que não seja ele próprio quem as desempenhe com esse fim, como no conto "O rei Barbade-melro" (ANEXO 8), em que o caráter da protagonista se transforma depois que ela é submetida intencionalmente a situações difíceis por seu marido (coadjuvante). No caso dos contos de fadas, o protagonista sempre interage com seres sobrenaturais ao longo de seu percurso: os do bem o ajudam e os do mal o atrapalham.

Como nos mostra Propp, em muitas seqüências o protagonista vence o antagonista; em outras ele realiza uma tarefa difícil - estes dois pares de funções (combate e vitória; imposição da tarefa e sua realização) muito raramente aparecem numa mesma seqüência, embora possam estar presentes num mesmo conto, em seqüências diferentes. Há ainda outros contos nos quais não há nenhum dos dois pares de funções. São formas diferentes de se configurar um conflito e os acontecimentos em torno dele. Temos um exemplo do primeiro caso no conto "O castelo de Soria Moria" (ANEXO 24) em que o protagonista luta com trolls e os vence. O segundo caso pode ser observado no conto "O quadro de pano" (ANEXO 22): o conflito começa a se configurar quando uma mulher, ao deparar-se com uma "linda tela" na feira onde costumava vender seu artesanato, decide comprá-la para copiá-la em brocado, mas apenas para seu prazer e não para vender. O conflito se evidencia quando o quadro é levado pelos ventos (constelando-se o que Propp denominou "carência"), deixando-a completamente desolada até cair gravemente enferma. Seu filho mais novo é o único que consegue realizar a tarefa difícil de resgatar o quadro de pano. 


\section{VI- METÁFORAS DO CONTO POPULAR OU O CONTO POPULAR COMO METÁFORA}

\section{Pulsação e transformação: equilibração majorante}

O coração pulsa: contrai-se e expande-se. Assim, bombeia sangue para o corpo todo através das artérias, que também pulsam. Os músculos se contraem e se expandem. Cada célula de nosso corpo faz movimentos de expansão e contração. Mesmo quando estamos dormindo, bem quietinhos, esses movimentos todos estão acontecendo em nosso corpo. A respiração continua: os pulmões se enchem de ar, depois se esvaziam. E assim será enquanto estivermos vivos. Podemos dizer que a vida humana (e não somente a humana) está intimamente relacionada com um contínuo contrair-expandir. Tensão-relaxamento. O próprio nascimento se dá a partir da pulsação do útero, que sofre contrações periódicas, enquanto o canal vaginal se dilata para que o bebê passe.

A idéia de pulsação não se restringe a toda forma de vida no planeta Terra: segundo teorias astronômicas modernas, o universo pulsa - desde a imensa explosão conhecida como "Big Bang", as galáxias estão se afastando umas das outras e assim seguirão até o momento em que começarem a se juntar novamente numa massa compacta. E então provavelmente haverá um novo "Big Bang."

À primeira vista, pode parecer que são somente dois estados que se alternam: o de expansão é seguido do de contração, depois se retorna para o estado anterior, sem mudar nada. Mas na verdade, na passagem de um estado para outro, ocorrem transformações. Ou seja, as coisas tendem a retornar a uma situação semelhante àquela da qual partiram, mas ocorrem mudanças no decorrer do processo. A cada respiração nosso corpo se modifica; a cada segundo vamos ficando mais velhos.

O ritmo da pulsação do coração é diferente para cada ser humano. Se pegarmos eletrocardiogramas de várias pessoas, veremos que não são iguais. É como se cada coração tivesse a sua assinatura. Além disso, um mesmo coração pode pulsar rápido ou devagar: quando estamos relaxados, tranqüilos ou em repouso, a velocidade é lenta. Se estamos tensos, preocupados ou nos 
movimentando, o coração acelera. Alterações na velocidade e ritmo da pulsação cardíaca também podem ser ocasionadas pela ingestão de algumas substâncias, mas mesmo isso pode variar de uma pessoa para outra. Em geral, quando damos conta de resolver os problemas que causaram a tensão (em outras palavras, se conseguirmos solucionar o conflito), voltamos a relaxar. Infelizmente, algumas vezes demoramos muito para resolver um problema ou sua solução não está ao nosso alcance; então acabamos desenvolvendo uma tensão crônica. Mas quando conseguimos recuperar o equilíbrio após um período de desestruturação, ocorre um processo no qual algo se transforma: depois que enfrentamos e superamos um problema, já não somos mais os mesmos. Piaget utilizou o termo equilibração majorante para falar desse processo e tomou como ícone para representá-lo uma espiral cônica tendo o vértice como base: forma abstraída dos moluscos que estudava. Ou seja, quando algo rompe um estado de equilíbrio, tendemos a retornar a ele, mas não sem que antes ocorram transformações: a espiral vai se alargando. Nos contos populares, o conflito provoca o rompimento do equilíbrio e os acontecimentos em torno dele preparam sua restauração, mas nunca sem que aconteça uma transformação.

Artesanato e conto popular: algumas considerações sobre a experiência estética $^{1}$

Os objetos de artesanato pertencem a um mundo anterior à separação entre 0 útil e 0 belo. (...) A persistência e a proliferação do enfeite no artesanato revelam uma zona intermediária entre a utilidade e a contemplação estética. No artesanato há um contínuo vaivém entre utilidade e beleza; esse vaivém tem um nome: prazer. As coisas dão prazer porque são úteis e belas. (...) 0 objeto artesanal satisfaz uma necessidade menos imperiosa que a sede e a fome: necessidade de nos recrearmos com as coisas que vemos e tocamos, quaisquer que sejam seus usos diários. Essa necessidade não é redutível ao ideal matemático que rege 0 desenho industrial, nem tampouco ao rigor da religião artística. $O$ prazer que nos é dado pelo artesanato brota de uma dupla transgressão: ao culto da utilidade e à religião da arte. (PAZ, Octavio. Convergências. p. 45-51)

O texto sugere-me uma metáfora: o conto popular é o artesanato da literatura.

Esses contos são feitos do barro do inconsciente de um povo e cozidos no

\footnotetext{
1 Conceitos tais como "experiência estética" e "objeto de self" presentes neste item correspondem a anotações feitas em aulas ministradas pelo professor Gilberto Safra neste Instituto.
} 
forno de uma cultura. São, como o artesanato, do tempo em que "o sentido e o ser se confundiam num nó indissolúvel: a divindade" (PAZ, Octavio - Idem). Cada conto é um vaso de imaginação, uma gamela para conter angústias, um pote para receber jorros de emoção, um jarro para verter, inverter, reverter acontecimentos internos que são da ordem do inexplicável - mas o conto, assim mesmo, explica. Sutilmente organiza, propõe uma trama, apresenta um drama, encena um poema. $^{1}$

Tradicional, regional e universal a um só tempo, cada conto popular traz um pouco da história do humano. Cada cultura põe seu tempero, mas há elementos estruturais que se mantêm e podem ser observados em contos de diferentes cantos do mundo. Há em comum com o artesanato também a utilidade aliada a uma beleza peculiar e simples. Em Um método de consulta terapêutica através do uso de estórias (SAFRA, Gilberto), podemos nos deliciar com um claro exemplo dessa utilidade: em cada caso apresentado, uma história é criada com uma criança e seus pais, no consultório, com fim especificamente terapêutico, isto é, para curar uma relação familiar.

Nos contos da tradição oral, muitas vezes identificamos aspectos nossos, às vezes até mesmo sem que nos demos conta. (As crianças em geral percebem logo quais contos lhes são úteis e pedem que se os contem infinitas vezes.) Podemos recorrer à interpretação para elucidar esses aspectos, numa tentativa de compreendê-los melhor. Ou podemos ficar simplesmente com o efeito silencioso e denso que certos contos (assim como certos objetos, cenas etc) detonam em nós - algo que se poderia chamar de impacto estético. É um

\footnotetext{
1 "Fatos não se explicam com fatos, fatos se explicam com fábulas. A fábula é o desabrochar da estrutura, arquétipo em flor. Uns são transformados em flores, outros são transformados em pedra, outros ainda, se transformam em estrelas e constelações. Nada com seu ser se conforma. Toda transformação exige uma explicação. O ser, sim, é inexplicável. (...) É realmente preciso imaginar o horror, até o limite do horror, imaginar livre além de toda repugnância, permitir-se imaginar até as extremas fronteiras onde a imaginação, em delírio, reduz a realidade à pobreza de uma pedra? Sob as espécies de fábula, pensa-se o impensável, invade-se o proibido, viola-se o interdito, há uma lenda que diz, um dia, tudo vai ser dito. As histórias, sozinhas, se contam entre si. A fábula do Minotauro narra a saga de Perseu para um público de Medusas. Os homens são apenas os órgãos sexuais da fábulas. Qualquer fábula vive mais que uma pirâmide do Egito. Ouvir e contar histórias pode ser a razão de uma vida. Essa vida, talvez, um dia, alguém a conte. E quem conta um conto, sempre acrescenta um ponto, um detalhe novo, uma articulação imprevista, uma aproximação com outras fábulas. (...) Fábulas são sábias. Não há nenhuma fábula sobre isso. Conta-me uma anedota, e dir-te-ei quem és. Tal homem, tal fábula." (LEMINSKI, Paulo. Metaformose: uma viagem pelo imaginário grego. p. 23-24) Observação: Neste texto o autor faz um uso múltiplo do termo "fábula", utilizando-o de forma genérica, para designar o que defini como "conto maravilhoso", o que usualmente se denomina "mito" e também outros tipos de histórias.
} 
fenômeno que tem importância em si, por sua função simbolizante; portanto, não pede interpretação e sim reconhecimento. Algo que é como uma revelação, um encontro, uma forma oferecida para um "saber de si mesmo" que já estava ali, à espera de uma gamela, um vaso, algo que the desse contorno.

Como acontece, aliás, com a artesã do conto "O quadro de pano" (ANEXO 22). Ela tece por muitos anos para garantir o sustento da família, até que um dia, caminhando pela feira onde vendia seus brocados, depara-se com uma tela que Ihe rouba o fôlego. Vemos então desdobrar-se a criação a partir de um impacto estético: usando a tela como modelo, ela passa a tecer por prazer, incorporando ao bordado suas lágrimas, seu sangue. A tela que a mulher vê na feira é um objeto que se inscreve em seu campo de significação, em seu imaginário - uma experiência de encontro, a partir da qual sua vida se transforma. Ali ela encontra um objeto de self, ou seja: um objeto no qual estava estampado seu estilo de ser. Literalmente, no conto, ela "torna seu" este objeto (tela) copiando-o, tecendo-o, num processo dedicado e sofrido. Depois, quase morre quando o vento o leva pelos ares. Ao recuperá-lo, à custa de muito empenho e sofrimento, a paisagem nele retratada se desenrola sobre seu mundo, tornando-se realidade.

Nesta situação, foi justamente o corte - a possibilidade de, ao interromper a atividade útil diurna, debruçar-se sobre um sonho - que proporcionou à mulher oportunidade de transformação. Os filhos mais velhos, ao verem pronto o quadro de pano, logo pensaram na soma em dinheiro que ele poderia representar, como se sua utilidade pudesse ser comparada à dos trabalhos tecidos durante o dia. Mas ela tecera por prazer, demorando-se sobre o belo, para contemplar. Não para vender ou para servir como toalha - simplesmente para contemplar. Sua utilidade está em seu poder transformador, revelador, criador. Que não é igual para todos, pois diz respeito a um mundo único, pessoal. Quantas pessoas já não teriam passado pela tela na feira, sem que esta nada lhes dissesse?

Mais um exemplo: um dia, fim de tarde, o sol se punha luminoso, finalizando um dia muito claro, depois de muitos dias de chuva. Alguém ao telefone comentou: "Parece que vai dar um pôr de sol bonito". Ao desligar, fui olhar. De repente, rapidamente, nuvens se aglomeraram no horizonte e começou a chover. Chuva constante, não muito forte, porém consistente. $O$ cenário que se criou 
então foi de uma beleza absurda. Entre o sol começando a alaranjar e a camada de nuvens escuras, via-se um nítido pedaço de céu azul. $\mathrm{O}$ amarelo tingia tudo em volta, inclusive as gotas de chuva. E era como se chovesse dentro de mim. Meus olhos também choviam, naquele mergulho em meu mundo. Algo parecia ao mesmo tempo revelar-se e ser recordado: o paradoxo da surpresa diante do reconhecimento. Quando saí do "transe", pensei: "experiência estética". Mais tarde, ouvi a seguinte queixa: "Você viu, foi só eu dizer que o pôr do sol ia ser bonito e começou a chover!" Ou seja: o que me causou um impacto estético foi, para outrem, uma grande decepção.

Não se trata apenas de papagaiar Einstein, "tudo é relativo, tudo é relativo..." A experiência estética envolve um encontro. É o "prazer diante de uma coisa recortada como bela" (nas palavras de Gilberto Safra). Essa coisa tem, então, um sentido. Nesse plano, a beleza não está no objeto. $O$ objeto pode ter uma "utilidade" enquanto oportunidade para criar. E a experiência estética pode acontecer em diferentes níveis - desde "esse objeto me agrada" até "esse objeto me leva a nocaute, me põe em transe". Desde um bonito vaso de barro mexicano que conservo ao lado de minha mesa de trabalho (e que não serve para pôr flores, pois verte água pelo fundo!) a um pôr de sol com chuva. Ou, mais ainda, uma tela de Munch chamada "A Consolação" que estava no espaço mais refrigerado da Bienal de 96. Para mim, ao menos, a tela foi útil. A própria beleza tem, aqui, sua utilidade. A beleza é o sentido; a coisa tem beleza porque tem sentido. É o objeto como símbolo apresentativo, ou seja: como tradução icônica de um sentimento. Apresentativo no sentido de que apresenta o sujeito a si mesmo.

Voltando aos contos populares, vejo neles características que lhes permitem funcionar como símbolos apresentativos. Esses contos, como sonhos e mitos, têm uma importância em si. Interpretar é uma tendência; em alguns momentos, pode ser útil. Mas, ao menos num primeiro momento, considero mais proveitoso deixar que o conto entre e se acomode. Mesmo que o impacto provocado por ele não seja agradável - nem por isso é menos estético. A beleza está no sentido, na verdade que o conto cutuca dentro, em seu poder de revelar, de revolver alguma coisa em nosso mundo interno. Participei uma vez de um curso no qual uma 
mulher se indignou com o conteúdo de um conto; queria mudar o fim da história. Tomado literalmente, o desfecho era revoltante. Mas será que vale a pena recusar os fatos (tantas vezes absurdos) dos contos? Ou tentar traduzi-los rapidinho, para diminuir a ansiedade? É verdade que o impacto é muitas vezes como uma facada. Mas justamente porque tem a ver comigo, ou nem me tocaria. $\mathrm{E}$, porque tem a ver comigo, me ensina algo de mim. 


\title{
VII- DISCUSSÃo E CONSIDERAÇÕES FINAIS
}

\author{
Impacto estético na leitura e na escrita
}

(...) Os clássicos são livros que, quanto mais pensamos conhecer por ouvir dizer, quando são lidos de fato mais se revelam novos, inesperados, inéditos.

Naturalmente isso ocorre quando um clássico "funciona" como tal, isto é, estabelece uma relação pessoal com quem o lê. Se a centelha não se dá, nada feito: os clássicos não são lidos por dever ou por respeito mas só por amor. Exceto na escola: a escola deve fazer com que você conheça bem ou mal um certo número de clássicos dentre os quais (ou em relação aos quais) você poderá depois reconhecer os "seus" clássicos. A escola é obrigada a dar-lhe instrumentos para efetuar uma opção: mas as escolhas que contam são aquelas que ocorrem fora e depois de cada escola. (CALVINO, Italo. Por que ler os clássicos, p. 12-13)

\section{Entendendo-se impacto estético como "o prazer diante de algo recortado} como belo", creio que é a isto que se refere Calvino ao falar de uma centelha que se dá quando se estabelece uma relação particular entre leitor e texto.

Considero esta discussão especialmente importante no contexto do "ensino" da redação. "Ensino" aqui vem entre aspas porque a experiência de escrever, assim como a de ler, é uma relação peculiar que se constrói a cada letra. Relação esta precedida por séculos de história, nos quais, cabe lembrar, há uma tradição de proibição, de restrição: a leitura e a escrita, há relativamente pouco tempo, estavam circunscritas a um pequeno grupo de religiosos e/ou poderosos. ${ }^{1}$ Se voltarmos ainda mais no tempo, veremos que (como mostra Propp em Las Raíces historicas del cuento, conforme a citação de Nádia Gotlib, em nota de rodapé do item V.4.c) o próprio direito de contar histórias em alguns contextos era limitado a determinadas pessoas, revestidas de poderes especiais.

Assim, antes de mais nada, no "ensino" de redação é necessário que a

\footnotetext{
1 "Nossa posição contemporânea nos faz considerar que os leitores de todos os tempos sempre leram como nós. O importante é recuperar as descontinuidades na história da leitura. Acho que há duas rupturas fundamentais. Uma, muito distante, que é o momento em que cresceu o número de leitores que liam com os olhos, de forma silenciosa, e que não mais precisavam da oralização. Este movimento atravessou toda a Idade Média ocidental e trouxe a interiorização do ato de leitura como atividade ligada ao recolhimento, à solidão. A segunda grande ruptura ocorreu, no século 18, quando surgiram mais leitores graças ao processo de alfabetização na maior parte da Europa. O livro se tornou mais acessível com um preço menor. Multiplicaram-se as instituições onde se podia ler sem comprar, como as bibliotecas e gabinetes de leitura. (...) O conjunto de textos disponíveis aumentou e a leitura se tornou menos religiosa e sacralizada. Essa transformação na relação com o livro trouxe o nascimento de uma primeira forma de espaço público no século 18, quando se desenvolveu uma relação crítica com os textos da autoridade e foram lidas obras proibidas ou subversivas.” (CHARTIER, Roger. Folha de São Paulo 6-7, 28 de novembro de 1993.)
} 
solidão diante do papel em branco seja em primeiro lugar vista, considerada. É improdutivo negar que escrever seja, histórica e simbolicamente, um ato de transgressão. Tomar para si um papel de deus, que inventa, cria, manda e desmanda no destino de palavras sobre o papel e personagens a que elas dão forma é um gesto de responsabilidade. Ao mesmo tempo, um texto produzido é uma oportunidade que damos ao mundo de exercer sobre nós um julgamento. Isso precisa ser levado muito a sério. Crianças pequenas têm noção de que se expõem nos textos; talvez mais até do que o percebem em relação aos desenhos. Assim, é preciso que se ofereça a esses "aprendizes" um contexto no qual possam transitar nesse mundo sentindo que sua "solidão" é percebida, respeitada e que não se pretende negá-la, mas antes oferecer-Ihe companhia. Não se trata de dizer: "Imagine, escrever é fácil, eu vou te ensinar um jeito fácil de escrever, um jeito que é só gostoso!!!" Não. Trata-se de transmitir a idéia: "Meu bem, eu sei que escrever não é uma coisa simples, às vezes pode ser muito complicada; mas também pode ser muito divertida... Nós vamos ver juntos que há momentos gostosos e outros difíceis, mas a gente pode superar essa dificuldade." Ou seja: nem tudo pode ser prazeroso, mas podemos lidar de um jeito lúdico com o que não o seja.

A partir dessa premissa, podemos proporcionar um contexto em que seja possível ocorrer a tal "centelha". Trata-se de oferecer leituras, narrações e experiências entre as quais cada aluno possa sofrer impacto estético, possa ser tocado, nesse momento em que experimenta algo significativo. Neste ponto, discordo de Calvino: por que é que a escola tem de se resignar a esse papel de fazer com que se "conheça bem ou mal um certo número de clássicos"? Aqui cabe um comentário sobre a preocupação - aliás, legítima - que tem todo professor (incluo-me) em transmitir o tal do "conteúdo", ou seja, a matéria, o conjunto de informações correspondentes a algo pré-estabelecido - como, por exemplo, a série escolar. O conteúdo é importante, sem dúvida. Mas o modo como ele é apresentado faz toda a diferença no que diz respeito a como será recebido e quanto será assimilado pelos alunos. Mais vale pouco conteúdo, bem assimilado, do que muito, mal assimilado. ${ }^{1}$ Ou corremos o risco de nos tornar

\footnotetext{
1 “(...) a solidez do saber é função da atividade dispendida para sua assimilação. (...) De um modo geral, a
} 
professores "tarefeiros", dando aulas inevitavelmente chatas, por maior que seja a nossa boa vontade em não sermos chatos. Voltarei a isso mais demoradamente logo adiante.

De fundamental importância é também que o que se propõe seja - direi isso, embora pareça óbvio - significativo também para quem propõe, ou seja, para o coordenador do grupo de criação textual. Afinal, é preciso ser muito caradura para se vender um peixe que se crê podre...

\section{Uma dupla perspectiva: pedagógica e psicológica}

Retomando, então: a estrutura dos contos populares pode ser considerada uma estrutura simples, a partir da qual se desenvolveram outros tipos de histórias, com estruturas diferentes. Assim, conhecer a estrutura simples dos contos populares pode ser útil para escrevermos nossas próprias histórias. Neste estudo realizei várias experiências visando instrumentalizar crianças para escrever contos, tomando como modelo básico os contos populares de magia, com uma perspectiva mais ampla de que esta aquisição pode fornecer bases para o desenvolvimento da escrita em outras situações.

Ao lado disso, de forma sutil e inconsciente, as imagens desses contos têm o seu poder de cura ou de profilaxia das "doenças do viver" e - por que não dizer? - das "doenças do aprender". É claro que isso tem seus limites, pois há casos de perturbações muito graves em que não adiantaria apenas contar e criar histórias; ainda assim, o poder de elaborar conflitos internos que as histórias têm é algo conhecido de todos e pode ser utilizado conscientemente (isto é, "propositalmente") nas escolas. Ou seja, isto pode ser usufruído como uma oportunidade para que se constitua um espaço de expressão da subjetividade, onde cada aluno possa viver criativamente.

Penso valer a pena considerar que criar histórias em sala de aula pode ter um papel semelhante ao desempenhado pelas histórias criadas em contexto clínico na proposta de Gilberto Safra, em Um método de consulta terapêutica através do uso de estórias infantis. Ou seja, pode oferecer oportunidade para que 
as crianças curem, em alguma medida, sua relação com o "estar na escola", proporcionando um afrouxamento dos nós envolvidos na experiência de aprender. Cada criança tem seu drama particular, e é justamente por isso que os contos podem ser úteis: eles oferecem a possibilidade de se trazer para um campo coletivo o que é da ordem do individual, sem transformar aulas em sessões de psicoterapia de grupo. Trata-se de voltar o olhar, sim, para os dramas psicológicos das crianças dentro da sala de aula, porém sem psicologizar a escola. Pode ser uma forma de trabalhar a velha questão da separação irreal entre o ser cognoscente e o ser psíquico, oferecendo uma oportunidade de integração em que se pode acolher o ser que aprende e sente dentro de um corpo.

\section{Alinhavo}

O trabalho realizado tornou claro que tipos de atividades, dentre as utilizadas, tiveram melhores resultados no contexto das Oficinas de Redação e Criatividade. Ou seja, como vimos, procurei avaliar a repercussão que elas tiveram em termos de interesse (pelas atividades em si e por leitura e escrita em geral) e desempenho na escrita, tomando como referência a observação nas próprias oficinas, os textos produzidos, os questionários respondidos pelas crianças e também os depoimentos dados em entrevistas por mães e professoras.

Todos os dados apontaram para uma sensível melhora quanto ao desempenho na escrita. É gratificante perceber o crescimento na redação das crianças, especialmente ao observar os textos produzidos.

Quanto ao interesse, alguns fatos são indicadores do envolvimento que as crianças tiveram com as oficinas, de maneira geral. Em primeiro lugar, a assiduidade foi espantosa. Duas crianças compareceram até mesmo de cadeira de rodas: no primeiro semestre Graziela foi atropelada e trincou a bacia; no segundo semestre Celso machucou o pé lutando judô. A permanência de todas as crianças no grupo no período de quase dois anos é também um fato digno de 
nota, bem como a reação diante da proximidade do fim de um semestre ou do fim do ano: a maioria "protestava" porque as oficinas iam parar. Após um período de um ano e meio, quatro crianças confirmaram seu desejo de dar continuidade ao trabalho, uma ficou em dúvida e outra estava decidida a não mais comparecer. Todas, no entanto, acabaram freqüentando as oficinas até o final, cumprindo o compromisso feito comigo de terminar o "texto do livro".

Chamou a atenção também o depoimento das mães e professoras, segundo o qual todas as crianças demonstraram maior interesse ou disposição para realizar atividades de leitura e escrita depois de terem começado a freqüentar as oficinas.

Evidentemente, ao final de todo o processo, é possível ter uma visão de conjunto, global, que permite avaliar as propostas, fazer um "balanço" e desenvolver outras novas. Não se partiu de uma metodologia pronta, a fim de testá-la: a própria realização das oficinas foi tornando claro que tipo de vivência e informação era importante, útil e significativo. E com certeza um trabalho como esse é "sem fim": a cada oficina, novas descobertas indicam novas possibilidades. Ao longo do relato das oficinas, alguns aspectos foram levantados no sentido de fazer uma ponderação das atividades propostas, apontando meus erros e muitas vezes propondo alternativas possíveis para as situações que se revelaram improdutivas.

Os resultados do trabalho nas oficinas confirmaram minha filiação teórica. Saltou aos olhos a importância do trabalho em equipes, tão defendido por Piaget como facilitador do fazer ativo daquele que aprende. Quero ressaltar que esse fazer ativo implica necessariamente um envolvimento da criança, de modo que não basta simplesmente proporcionar a ela oportunidades para um "fazer" qualquer, mas sim um fazer interessado, entregue - exatamente o que entendo como sendo aquilo a que Sanny S. da Rosa se refere ao defender um fazer que seja "expressão do ser", um fazer pleno de sentido para aquele que faz. ${ }^{1}$ Aqui

\footnotetext{
1 “(...) na condição de professores-educadores, não raro esquecemos da pessoa (ser=self) do aluno reivindicando exclusivamente o seu fazer. Alguns poderão objetar que a tarefa do professor não se confunde com a da mãe, e mais, quer ela tenha sido suficientemente boa ou não, o que se espera do aluno na escola é muito diferente do que se espera do paciente no divã. Tal objeção é justa, e no limite, se quisermos aproveitar as teses winnicottianas na educação, será necessário sem dúvida adaptá-las a esta realidade específica. Todavia, a mesma observação pode ser usada como reforço das dissociações vividas no interior da escola. Será preciso, então, compreender que aquilo que Winnicott apresentou como padrão desejável das relações
} 
quero levantar a discussão mais importante desta dissertação. O interesse das crianças pelas oficinas, que de forma geral pareceu bastante grande, oscilou em alguns momentos e tenho bons motivos para afirmar que ele diminuiu todas as vezes em que certas "necessidades" da professora - eu - atravessaram a experiência em si.

Seguramente é mais importante que as crianças adquiram conhecimentos que sejam significativos para elas, ainda que em pequena quantidade, do que um volume grande de "conteúdo decorado" e até mesmo uma alta "produtividade" de tarefas, quando se trata de - ainda na linguagem winnicottiana - oferecer às crianças um espaço de ilusão, construindo para elas o "espaço potencial", ${ }^{1}$ em que poderão criar. Eu diria que em muitos momentos conseguimos (as crianças e eu) êxito nesse sentido; noutros momentos, não. Muitas vezes passei perto do "triângulo das bermudas", do buraco negro das tarefas que "precisamos" cumprir, conteúdos que "precisamos" transmitir etc. É aí que a experiência corre o risco de naufragar, perder-se no compacto vazio do conteúdo destituído de significado vivenciado, experimentado e, como diria Piaget, construído. Por sorte e também por amor - imenso era o desejo de oferecer a meus alunos queridos uma experiência rica - na maior parte das vezes percebi o risco e retomei a rota, salvando-nos do desastre. Sinto que foi muito também por amor que as crianças foram tão fiéis ao compromisso de terminar o último texto e revisá-lo exaustivamente, daquela forma que eu estava, na época, convencida de que era a única possível. Só o amor não teria sido suficiente: é claro que elas percebiam que eu estava tentando acertar, propondo as discussões em grupo, por exemplo, e até mesmo compartilhando com elas o que tinha percebido, como fiz na oficina 17. Penso serem estes os ingredientes mais importantes para o sucesso de qualquer experiência pedagógica: uma boa relação entre alunos e professor e um

mãe-criança se estende a todas as relações "eu-outro" e às diversas fases da vida de uma pessoa. Disso decorre que também, e talvez principalmente na escola - visto ser este um lugar potencialmente privilegiado de criação - a indissociabilidade do self deve ser buscada como meta; e que cabe, sim, ao educador a tarefa de cuidar de que o fazer de seu aluno torne-se expressão de seu ser.” (ROSA, Sanny Silva da. A dissociação do self e suas implicações na educação. Revista Percurso, n. 17, $2^{\circ}$ semestre de 1996, p. 78)

1 “(...) enquanto a realidade psíquica interna possui uma espécie de localização na mente, no ventre, na cabeça ou em qualquer lugar dentro dos limites da personalidade do indivíduo, e enquanto a realidade externa está localizada fora desses limites, o brincar e a experiência cultural podem receber uma localização caso utilizemos o conceito do espaço potencial existente entre a mãe e o bebê." (WINNICOTT, Donald. $\underline{\text { O brincar }}$ e a realidade. p. 79) 
imenso desejo deste último de acertar, acreditando sempre que possam existir, para quaisquer conteúdos, formas que cativem seus alunos, prendam-Ihes a atenção, despertem-Ihes o interesse, convidando-os a dialogar, perguntar, pesquisar, experimentar, descobrir... Criar. Esse é um grande desafio para o professor. Dar conteúdos "mastigadinhos" em forma de aulas expositivas é uma tendência que provavelmente resulta da forma como nós, que hoje somos professores, aprendemos a aprender. ${ }^{1} \mathrm{E}$ certamente há nisso boa vontade de nossa parte ou ao menos uma crença, ainda que inconsciente, de que esta é a melhor forma possível, que vai "facilitar" a vida dos alunos etc. Então, diante de seus bocejos, facilmente caímos na tentação de atribuir a eles a responsabilidade pelo fracasso da atividade, uma vez que nós sinceramente nos empenhamos para dar uma "boa aula". No entanto, os "humores" dos alunos são um ótimo indicador do quanto a atividade proposta está sendo significativa para eles.

Pode-se objetar, em relação a este estudo, o fato de ter sido desenvolvido em um contexto específico, recortado, muito diferente da realidade de uma sala de aula, em que é preciso dividir as atenções entre muitas crianças. Em contrapartida, as professoras (especialmente do primeiro e segundo ciclos) têm uma ampla vantagem: a continuidade no convívio, dia a dia, construindo a relação com seus alunos, sendo que eu realizei encontros semanais (nem sempre tão regulares, devido a feriados e outros fatores).

Para fechar, quero dirigir-me diretamente a todos os professores que me estiverem lendo: sejamos persistentes! Precisamos aceitar o desafio de descobrir uma forma eficiente para qualquer conteúdo. Eficiente no sentido de poder proporcionar aos alunos uma experiência significativa. Significativa no sentido de despertar-Ihes o interesse, prender sua atenção, cativá-los. É preciso pesquisar à exaustão: consultar colegas, livros, meditar, sonhar, fazer novena... Acreditemos: se uma atividade não está dando certo, sempre vale a pena tentar uma nova

\footnotetext{
${ }^{1}$ Volto aqui à expressão presente na dedicatória deste texto. Por falar em contar histórias, aí vai um "momento biográfico": depois de ter aprendido a aprender brincando, em casa, e estudado por três anos numa escola de vanguarda que nos anos 70 procurava aplicar idéias modernas em educação (hoje as reconheço como construtivistas), tive de mudar de cidade e adaptar-me a um colégio totalmente tradicional, a partir da segunda série do primário. É claro que, nessa escola, eu era "burra" - não sabia a tabuada de cor... Foi um grande choque para mim, acostumada a ser "líder de mesa" quando formávamos grupos, ouvir da professora: "Mas você não vai em Matemática, mesmo, né, Andrea..." Tive então de renegar meu passado para sobreviver naquele meio. Mas é um passado que procuro resgatar. Os momentos em que me torno "tarefeira"
} 
forma de propor o mesmo conteúdo. Quanto às formas sugeridas nesta dissertação, acompanha uma anti-bula: "Siga de forma absolutamente pessoal o modo de usar; não desaparecendo os sintomas, procure orientação da sua intuição ${ }^{1}$ e de pessoas disponíveis para dialogar sobre sua experiência. Não tenha medo de criticar o que você já fez e tentar fazer de outros jeitos. Seus alunos certamente perceberão o seu empenho e aprenderão com seu exemplo que não se deve desesperar nem resignar diante dos fracassos. E estarão ao seu lado. Uma boa relação sustenta os devires e inevitáveis deslizes da ação."

\footnotetext{
- facilmente observáveis nas oficinas - parecem-me recaídas...

1 "Num sentido positivo, o pensar faz parte do impulso criativo, mas existem alternativas ao pensar e elas possuem algumas vantagens sobre ele. Exemplificando, o pensamento lógico leva longo tempo e pode nunca chegar lá, mas o lampejo de intuição não leva tempo e chega lá imediatamente. A ciência precisa de ambas estas maneiras de progredir. (...) precisamos ser capazes de buscar símbolos e criar imaginativamente e em linguagem pré-verbal; precisamos ser capazes de pensar alucinatoriamente." (WINNICOTT, Donald. Explorações psicanalíticas. p.123)
} 


\section{VIII- REFERÊNCIAS BIBLIOGRÁFICAS}

ALLESSANDRINI, Cristina D. Oficina Criativa e Psicopedagogia. São Paulo, Casa do Psicólogo, 1996.

ANDERSEN, Hans Christian. O Patinho Feio. Porto Alegre, Kuarup, 1993. (Coleção "Era uma vez....")

AUBERT, Francis Henrik, org. Novas Aventuras de Askeladen. São Paulo, Edusp, 1995.

BARROSO, Márcio E. G. Dicionário Aurélio Eletrônico v. 2.0. Nova Fronteira,1996. Baseado no Novo Dicionário da Língua Portuguesa de Aurélio Buarque de Holanda Ferreira.

BERTAZZO, Ivaldo. Cidadão Corpo: Identidade e Autonomia do Movimento. São Paulo, SESC e Opera Prima, 1996.

BETTELHEIM, Bruno. A psicanálise dos contos de fadas. 10.reimp. São Paulo, Paz e Terra, 1995.

BONAVENTURE, Jette. O que conta o conto. São Paulo, Edições Paulinas, 1992.

CALIL, Eduardo. Por que escrever histórias inventadas. Jornal da Alfabetizadora, núm. 22.

CALVINO, Italo. Seis propostas para o próximo milênio. 2.ed. São Paulo, Cia das Letras, 1990. 1998.

Por que ler os clássicos. 5. reimp. São Paulo, Cia das Letras,

COELHO, Nelly Novaes. A Literatura Infantil. São Paulo, Quíron, 1984.

FERREIRO, Emília. A Formação do Leitor. Revista de la Educación del Pueblo. Montevideo, julho de 1992.

GOING, Luana Carramillo. Contos para escrever-se: Alfabetização por meio dos contos de fadas. São Paulo, Vetor Editora, 1997.

GOTLIB, Nádia Batella. Teoria do Conto. 2.ed. São Paulo, Editora Ática, 1985. (Série Princípios)

GRIMM, Jakob e Wilhelm. Os contos de Grimm. São Paulo, Paulus, 1989.

HAWKINS, Colin e Jacqui. Bruxas / Monstros. São Paulo, Martins Fontes, 1993. 
HIRSCH, Sonia. Deixa sair. 4ed. Caixa Postal 41004, Rio de Janeiro. (Edição independente)

JONES, Terry. Lady Cottington's Pressed Fairy Book. London, Pavilion Books Limited, 1994.

LIMA, Edvaldo Pereira. Da escrita total à consciência planetária. In: ZANCHI, R. F. B., ed. respons. Criatividade e Novas Metodologias. São Paulo, Fundação Peirópolis, 1998. p. 51-100. (Série Temas Transversais, v.4)

LEMINSKI, Paulo. Metaformose: uma viagem pelo imaginário grego. São Paulo, lluminuras, 1994.

MACEDO, Lino de. Ensaios Construtivistas. São Paulo, Casa do Psicólogo, 1994.

MACHADO, Irene A. Literatura e Redação. São Paulo, Scipione, 1994.

MACHADO, Regina. Arte educação e o conto de tradição oral: elementos para uma pedagogia do imaginário. São Paulo, 1989. Tese (Doutorado) Departamento de Artes Plásticas, Universidade de São Paulo.

MELLO $\mathrm{F}^{\circ}$, Julio de O ser e o viver: uma visão da obra de Winnicott. Porto Alegre, Artes Médicas, 1989.

MESERANI, Samir. Colégio 1. Redação Escolar: Criatividade. 8.ed. São Paulo, Saraiva, 1979. (v.1)

Os incríveis seres fantásticos. São Paulo, FTD, 1993.

O intertexto escolar: sobre leitura, aula e redação. São Paulo,

Cortez, 1995.

O prazer da redação. São Paulo, Ática, 1996.

PAZ, Octavio. Convergências: ensaios sobre arte e literatura. Rio de Janeiro, Rocco, 1991.

PERRAULT, Charles. O Chapeuzinho Vermelho. Porto Alegre, Kuarup, 1993. (col. "Era uma vez...")

PESSOA, Fernando. Obra Poética (em um volume). Rio de Janeiro, Companhia José Aguilar, 1972.

PIAGET, Jean. O estruturalismo. São Paulo, Difel, 1974.

O trabalho em equipes na escola. Última revisão (não publicada): 1998. Trad. Luiz G. Fleury; Adapt. Andrea A. Botelho. Publicado na Revista Psicopedagogia, 15 (36), p. 14-20, 1996. Publicação original: "Remarques psycologiques sur le travail par équipes", in Le travail par équipes à l'ècole / A. Jakiel et. al. Bureau Interantional d'Education, 1935. p. 179-196. 
Métodos pedagógicos e fins culturais. Trad. Márcia Zampieri Torres. In: Les méthodes nouvelles, leurs bases psicologiques et examen des méthodes nouvelles. Encyclopédie Française. Paris, Larousse, 1939.

PRIETO, Heloisa. Duendes e Gnomos: quase tudo o que você queria saber. / Magos, Fadas e Bruxas: quase tudo o que você queria saber. / Monstros e mundos misteriosos: quase tudo o que você queria saber. São Paulo, Companhia das Letrinhas, 1992; 1994; 1997.

PROPP, Vladimir I. Morfologia do conto maravilhoso. Rio de Janeiro, Forense Universitária, 1984.

QUENSEL, Alain; TORTON, Jean. A Grécia: mitos e lendas. São Paulo, Ática, 1995. (Série Mitos e Lendas)

RODARI, Gianni. Gramática da Fantasia. São Paulo, Summus Editorial, 1982.

ROSA, Sanny Silva da. A dissociação do self e suas implicações na educação. Revista Percurso, São Paulo, ano IX, n.17, $2^{\circ}$ semestre de 1996.

SAFRA, Gilberto. Um método de consulta terapêutica através do uso de estórias infantis. São Paulo, 1984. Dissertação (Mestrado) - Instituto de Psicologia, Universidade de São Paulo.

TEBEROSKY, Ana. "Escribir: para qué?", texto avulso. (Uma versão prévia do mesmo foi apresentada no I Congresso de Ação Educativa, Belo Horizonte, Brasil, julho de 1992.)

WINNICOTT, Donald W. O brincar e a realidade. Rio de Janeiro, Imago, 1975. Sul, 1994. Explorações psicanalíticas. Porto Alegre, Artes Médicas Fontes, 1996. Tudo começa em casa. 2.ed. São Paulo, Martins 